Instituto de Psicologia

Programa de Pós-Graduação em Psicologia Social, do Trabalho e das Organizações

Tese de Doutorado

Qualidade de Vida no Trabalho (QVT), Bem-Estar/Mal-Estar no Trabalho e Reconversão Tecnológica:

Representações de Trabalhadores em Empresa Pública Brasileira

Veruska Albuquerque Pacheco

Brasília, DF

2016 
Instituto de Psicologia

Programa de Pós-Graduação em Psicologia Social, do Trabalho e das Organizações

Tese de Doutorado

\section{Qualidade de Vida no Trabalho (QVT), Bem-Estar/Mal-Estar no Trabalho e Reconversão Tecnológica: \\ Representações de Trabalhadores em Empresa Pública Brasileira}

Veruska Albuquerque Pacheco

Tese aprovada como pré-requisito parcial para a obtenção do grau de Doutora no Programa de PósGraduação em Psicologia Social, do Trabalho e das Organizações da Universidade de Brasília.

Orientador: Prof. Dr. Mário César Ferreira

Brasília, DF 


\section{Universidade de Brasília}

\section{Qualidade de Vida no Trabalho (QVT), Bem-Estar/Mal-Estar no Trabalho e Reconversão Tecnológica: Representações de Trabalhadores em Empresa Pública Brasileira}

Tese apresentada como pré-requisito parcial para a obtenção do grau de Doutora no

Programa de Pós-Graduação em Psicologia Social, do Trabalho e das Organizações do Instituto de Psicologia pela seguinte banca examinadora:

Prof. Dr. Mário César Ferreira

Presidente - Instituto de Psicologia - Universidade de Brasília

Profa. Dra. Camila Costa Torres

Examinador Externo - Universidade Federal do Rio Grande do Norte

Profa. Dra. Tatiane Paschoal

Examinadora Externa - Departamento de Administração - Universidade de Brasília

Profa. Dra. Ana Lúcia Galinkin

Examinadora - Instituto de Psicologia - Universidade de Brasília

Prof. Dr. Francisco Antonio Coelho Junior

Examinador Externo - Departamento de Administração - Universidade de Brasília

Profa. Dra. Olgamir Francisco Carvalho

Examinador Suplente - Faculdade de Educação - Universidade de Brasília 


\section{AGRADECIMENTOS}

Este é um momento único. Escrever os agradecimentos é retomar quatro anos de histórias, sentimentos, muitas lembranças doces e algumas nem tanto, enfim, um turbilhão de emoções. E estar aqui, neste momento de consagração, é a oportunidade de relembrar e reconhecer o carinho, amor e dedicação das pessoas que estiveram ao meu lado.

Aos meus filhos, Guilherme e Mariana, por quem vivo, trabalho e luto diariamente, com um amor desmedido, incomensurável. Tudo por vocês, sempre.

Ao meu marido, Silvan, pelo amor, pelo companheirismo, pelo suporte sem o qual eu não teria como dar conta. Pela paciência nas noites insones, pela calma nos momentos de estresse, pelas palavras de apoio e pelo silêncio nas horas certas.

À minha mãe, Azenete, incentivadora de toda a vida. Obrigada por exigir, desde a infância, que eu sempre desse o melhor de mim nos estudos. Obrigada por dizer que iria dar tudo certo, que confiava em mim. Valeu a pena. Conseguimos!

À Deus. Agradecer sempre.

À minha família e meus amigos, em especial àqueles que me estimularam e me apoiaram, entendendo as ausências em tantos momentos. Ao meu irmão André, que desde o mestrado me "salvou" de armadilhas da tecnologia e me ajudou nas impressões e formatações, um obrigada particular! Família, amo todos vocês.

Às amigas que conheci na academia e que hoje são amigas da vida: Polyanna Andrade (Poly), Carla Antloga (Carlota), Janaina Daniel (Jana) e Marina Maia (Cat). Não haveria espaço nestas breves linhas pra expressar o tamanho do meu amor e gratidão por vocês. O "Tamo Junto" é real, é nosso, é imortal!!!

Ao meu orientador, Prof. Dr. Mário César Ferreira, pela confiança, pelo aprendizado, por compartilhar experiências e conhecimentos. Foram anos intensos e de muito crescimento. Gratidão eterna.

À gestão da UnB, por conceder afastamento para que eu pudesse me dedicar integralmente ao doutorado.

Aos professores e alunos do PSTO, pelo aprendizado compartilhado.

Aos professores e alunos do ErgoPublic, pelas discussões, pelas contribuições e trocas de experiência e conhecimento.

Aos trabalhadores da instituição pesquisada, especialmente à equipe responsável pelo projeto de QVT: Nilva Veiga, Ruth Lopes, Renata Gonsalves, Adolfo Pfeifer e Clara Bezerra.

Aos gestores e colegas das Faculdades Projeção, pela parceria e pelos espaços propiciados ao meu crescimento na docência. 


\section{Universidade de Brasília}

\section{SUMÁRIO}

Introdução

Artigo: Dimensões Estruturantes da Percepção de Qualidade de Vida no Trabalho (QVT): Estudo de Caso em Empresa Pública Brasileira

Artigo: Mal-Estar e Bem-Estar no Trabalho: Representações de Trabalhadores de Empresa Pública Brasileira

Artigo: Reconversão Tecnológica e Qualidade de Vida no Trabalho (QVT): Caso de Empresa Pública Brasileira

Conclusão

Referências Gerais 


\section{INTRODUÇÃO}

O presente documento apresenta o produto da pesquisa que origina na tese de doutoramento no Programa de Pós-Graduação em Psicologia Social, do Trabalho e das Organizações (PPG-PSTO) da Universidade de Brasília (UnB). Compõem o documento três artigos, intitulados:

A. Dimensões Estruturantes da Percepção de Qualidade de Vida no Trabalho (QVT): Estudo de Caso em Empresa Pública Brasileira.

B. Mal-Estar e Bem-Estar no Trabalho: Representações de Trabalhadores de Empresa Pública Brasileira.

C. Reconversão Tecnológica e Qualidade de Vida no Trabalho (QVT): Caso de Empresa Pública Brasileira.

Para a submissão dos artigos, selecionou-se as seguintes revistas: Artigo A: Revista de Administração (São Paulo) - RAUSP, Qualis A2; Artigo B: Psicologia: Teoria e Pesquisa, Qualis A1; e Artigo C: Psicologia: Ciência e Profissão, Qualis A2. Na construção dos artigos, buscou-se atender às normas e recomendações das revistas escolhidas. Ressalta-se que, em função das semelhanças das temáticas abordadas em cada artigo, além do estilo de redação, o/a leitor/a poderá encontrar alguns trechos redundantes.

O tema central desta tese é Qualidade de Vida no Trabalho (QVT). E em que contexto se insere essa temática na atualidade? Presencia-se, há algumas décadas, um cenário de constantes mudanças no mundo do trabalho. Esse panorama se constituiu especialmente com o advento da reestruturação produtiva, que teve impulso no final da década de 1960. A reestruturação produtiva foi marco da formação de uma nova configuração econômica, social e política que se contrapôs ao modelo taylorista/fordista. Desde então, em áreas diversas das ciências sociais, da saúde e humanas, temas como intensificação do trabalho, burnout, precarização do trabalho, estresse, mal-estar, entre outros vêm ganhando destaque tendo em vista os seus impactos negativos para a saúde física e mental dos trabalhadores e, consequentemente, para as organizações. Diante desse contexto, a temática qualidade de vida no trabalho, mesmo sendo estudada há algumas décadas, é ainda atual na academia. No contexto organizacional, sua busca tem se tornado estratégica seja nas instituições públicas seja nas empresas privadas.

A presente pesquisa realizou-se em uma empresa do serviço público federal, vinculada ao poder executivo federal. Trata-se de uma grande empresa pública brasileira, que possui regionais em diversas capitais, sendo duas em Brasília e as demais nas cidades de São Paulo, Rio de Janeiro, Recife, Curitiba, Salvador, Belém, Belo Horizonte, Porto Alegre, Fortaleza e Florianópolis.

O objetivo geral da pesquisa foi identificar as representações de trabalhadores sobre a qualidade de vida no trabalho em uma empresa pública brasileira. A pesquisa realizou-se sob o aporte da abordagem teórico-metodológica denominada Ergonomia da Atividade Aplicada à Qualidade de Vida no Trabalho (EAA_QVT), proposta por Ferreira (2012). A realização do diagnóstico foi feita em duas etapas complementares e interdependentes. 


\section{INTRODUÇÃO}

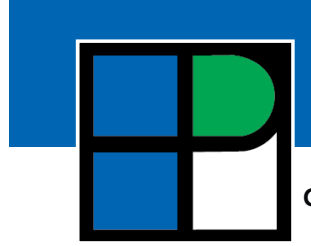

Grupo de Estudos Pesquisas em

A etapa 1, de macrodiagnóstico de QVT, realizou-se no segundo semestre de 2013 e teve como objetivos específicos:

- Descrever as características do contexto organizacional da instituição;

- Verificar os aspectos que estruturam o conceito de QVT sob a ótica dos trabalhadores;

- Identificar as fontes de bem-estar e mal-estar no contexto de trabalho;

- Descrever como os trabalhadores caracterizam:

$\diamond$ O contexto de trabalho;

$\diamond$ As práticas habituais de gestão do trabalho;

$\diamond \quad$ As vivências de desgaste e afetos positivos e negativos no trabalho.

A etapa 2, de nível microergonômico, realizada entre o final de 2014 e o início de 2015, teve como objetivos específicos:

- Identificar o impacto das exigências do contexto de trabalho e das práticas de gestão para os trabalhadores, ocasionadas por um processo de reconversão tecnológica;

- Mapear representações dos trabalhadores sobre as expectativas em relação ao processo de reconversão tecnológica;

- Mapear a percepção de QVT dos trabalhadores durante e após o processo de reconversão tecnológica;

- Identificar as Estratégias Operatórias de Mediação Individual e Coletiva (EMICs) que o os trabalhadores desenvolvem para lidar com o processo de reconversão tecnológica.
Justifica-se o desenvolvimento do projeto de pesquisa considerando três dimensões: social, institucional e científica. Na dimensão social, destaca-se a atualidade da discussão do tema em face do cenário do mundo do trabalho atual que, a cada dia, impõe novos desafios a gestores e trabalhadores. Ademais, estudos e intervenções em organizações públicas, cujo produto é a cidadania, podem nortear processos de mudança que se refletirão nos serviços prestados à sociedade. Do ponto de vista institucional, pesquisas desta natureza, por seu caráter aplicado, servem como um caminho para o enfrentamento dos dilemas que envolvem busca pelo equilíbrio entre os resultados organizacionais e o bem-estar de quem trabalha. $\mathrm{Na}$ perspectiva científica e acadêmica, qualidade de vida no trabalho é uma temática em voga nas agendas de pesquisadores nacionais e internacionais. Apesar de ser um construto discutido desde a década de 1970, ainda não há consenso sobre diversos aspectos que envolvem a QVT, como por exemplo a sua definição. Além disso, vislumbrase a perspectiva de contribuir para a consolidação da abordagem teórico-metodológica da Ergonomia da Atividade Aplicada à Qualidade de Vida no Trabalho - EAA_QVT.

O presente estudo trata-se de um estudo de caso de natureza quanti-qualitativa, ancorado na abordagem teórico-metodológica da EAA_QVT. Segundo Gil (2009), o estudo de caso caracteriza-se pela preservação do caráter unitário do fenômeno sem separá-lo do seu contexto, investigando-o in loco, com profundidade. O método permite, ainda, a utilização de múltiplos procedimentos de coleta de dados.

Por abranger uma dimensão quantitativa e uma dimensão qualitativa, esta pesquisa pode ser 
compreendida, portanto, como uma abordagem do tipo multimétodo. As duas abordagens propostas são entendidas como complementares, já que na primeira etapa foram identificadas questões para serem problematizadas e aprofundadas na segunda etapa. Esta perspectiva de análise permite o refinamento de reflexões sobre o objeto de estudo de forma a explicá-lo em suas múltiplas dimensões.

A EAA_QVT, cujo modelo descritivo encontra-se ilustrado na Figura 1, foi desenvolvida por Ferreira (2012) e vem sendo difundida por meio dos trabalhos desenvolvidos no Grupo de Estudos em Ergonomia Aplicada ao Setor Público ErgoPublic. No âmbito do ErgoPublic, foram realizados aproximadamente três dezenas de diagnósticos em qualidade de vida no trabalho no serviço público, predominantemente federal. A aplicabilidade da abordagem permitiu que as intervenções realizadas por meio dos diagnósticos, subsidiassem as instituições no desenvolvimento de política e programa de QVT.

Trata-se de uma abordagem em processo de consolidação, cujos projetos vêm sendo financiados pelo Conselho Nacional de Desenvolvimento Científico e Tecnológico (CNPq) e pelas pesquisas desenvolvidas no âmbito do PPG-PSTO. A abordagem fundamenta-se na Ergonomia da Atividade (Guérin et al., 2001; Wisner, 2004), que preconiza que é preciso compreender o trabalho para transformá-lo. É perspectiva dessa transformação a concepção de situações de trabalho que não causem prejuízos à saúde de quem trabalha, possibilitando o exercício de suas competências com possibilidades de valorização, bem como o alcance dos objetivos organizacionais. O modelo teórico-metodológico que descreve as dimensões e níveis de análise encontra-se ilustrado a seguir.

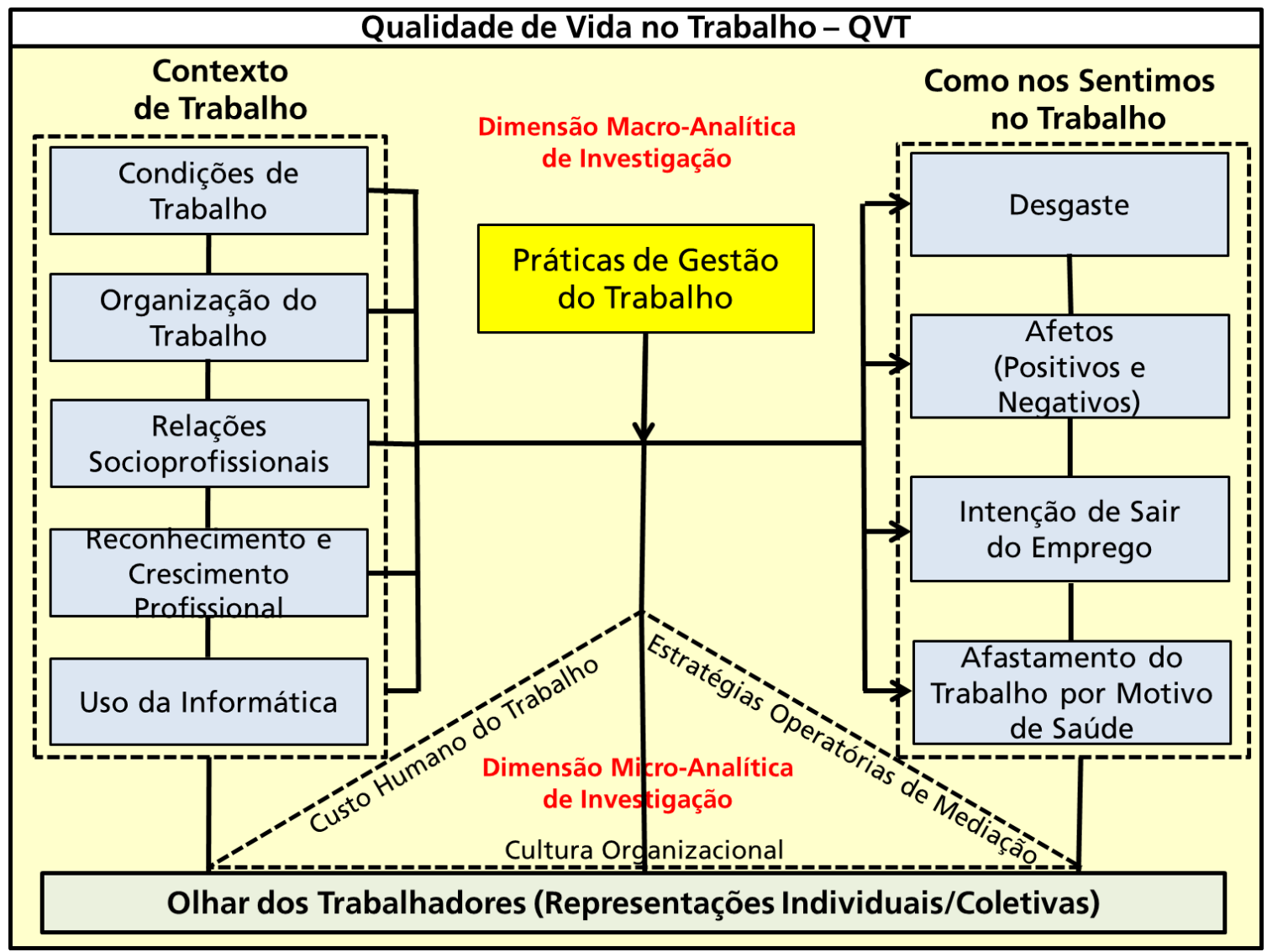

Figura 1. Modelo Teórico-Descritivo de Qualidade de Vida no Trabalho. Fonte: Ferreira, Paschoal e Ferreira (2013). 
Quanto ao nível de análise, o modelo é composto de dois níveis interdependentes: o primeiro é denominado dimensão macro-analítica (ou macroergonômica) de intervenção. O segundo é composto pela dimensão micro-analítica (ou microergonômica) de investigação.

De acordo com o modelo, a QVT nasce das representações individuais e coletivas dos trabalhadores com base em três eixos: Contexto de Trabalho, Práticas de Gestão e Como nos Sentimos no Trabalho, cujas características estão descritas a seguir.

- Contexto de Trabalho - Abrange as percepções acerca de cinco fatores:

a) Condições de Trabalho: Suporte instrumental (espaço físico, iluminação, mobiliário, posto de trabalho)disponibilizado no contexto organizacional.

b) Organização do Trabalho: Carga, pressão, tempo (pausa, execução com zelo) e a cobrança presentes no contexto organizacional.

c) Relações Socioprofissionais: Relações sociais concernentes à convivência, à confiança, ao acesso às chefias, à comunicação e à justiça na distribuição de tarefas.

d) Reconhecimento e Crescimento Profissional: Práticas de reconhecimento no trabalho e possibilidades de desenvolvimento profissional.

e) Uso da Informática: Qualidade de funcionamento do suporte de informática disponibilizado no contexto organizacional.

- Práticas de Gestão do Trabalho: Modo de gestão habitual presente no contexto de trabalho.
- Como nos Sentimos no Trabalho: Representações dos impactos que o trabalho tem nos trabalhadores, abrangendo quatro aspectos:

a) Desgastes: desgastes individuais provenientes do trabalho.

b) Afetos positivos e negativos: emoções e humores positivos e negativos vivenciados nos ambientes de trabalho.

c) Intenção de sair do emprego: desejo de deixar a instituição em função do contexto de trabalho, dos desgastes e dos afetos negativos.

d) Afastamentos por motivo de saúde: agravos à saúde que afetam as condições físicas e mentais dos trabalhadores e os impossibilitam de desempenhar suas atividades laborais.

O modelo proposto possui um delineamento correlacional, no qual as variáveis do contexto de trabalho são antecedentes e as variáveis referentes aos sentimentos no trabalho são consequentes. As práticas de gestão são moderadoras das relações entre os dois eixos.

No nível macroergonômico, o método de coleta de dados proposto é o Inventário de Avaliação de Qualidade de Vida no Trabalho (IA_QVT), instrumento quanti-quali. As características psicométricas encontram descritas no artigo intitulado "Dimensões Estruturantes da Percepção de Qualidade de Vida no Trabalho (QVT): Estudo de Caso em uma Empresa Pública Brasileira". O trajeto metodológico percorrido na etapa de macrodiagnóstico encontra-se ilustrado na Figura 2, já realizado em pesquisa anterior por Albuquerque (2011). 


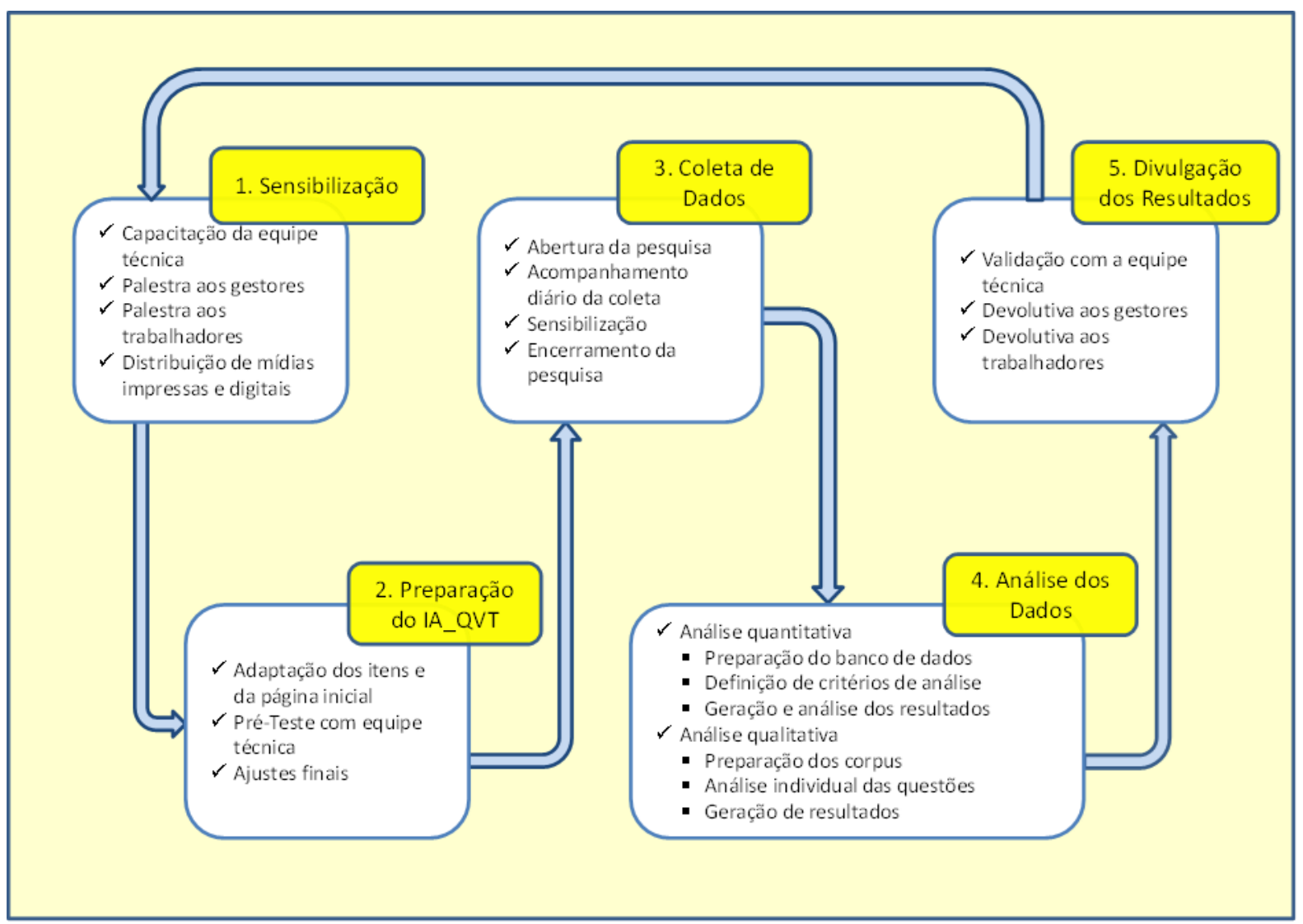

Figura 2. Trajeto metodológico da Etapa 1. Fonte: Albuquerque (2011).

A segunda dimensão de investigação é micro-analítica, também denominada microergonômica. Neste nível, investiga-se o Custo Humano no Trabalho (CHT) e as Estratégias Operatórias de Mediação Individuais e Coletivas (EMICS).

O Custo Humano no Trabalho representa o que é dispendido pelos trabalhadores, seja de forma individual ou de forma coletiva, em três esferas: física, cognitiva e afetiva, a fim de responderem às exigências impostas nos contextos laborais. (Ferreira, 2011).

O autor aponta três propriedades do CHT:

a) ele é imposto externamente aos trabalhadores, em face das características da produção, sob a forma de constrangimentos para suas atividades.

b) ele é gerido por meio das estratégias de mediação individual e coletiva (atividades) que visam, fundamentalmente, responder à discrepância entre as tarefas prescritas pelos modelos de gestão e as situações reais de trabalho.

c) ele está na origem das vivências de bemestar e mal-estar, modalidades de representações mentais, que os trabalhadores constroem sobre os efeitos do CHT. (Ferreira, 2011, p. 98).

Conforme elucidado acima, o CHT é gerido pelas Estratégias Operatórias de Mediação Individuais e Coletivas (EMICS), de maneira que, para lidar com $\mathrm{O}$ CHT, os trabalhadores desenvolvem formas de minimizar os impactos negativos desse custo gerado na execução das 


\section{INTRODUÇÃO}

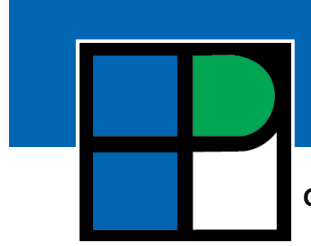

Grupo de Estudos Pesquisas em

tarefas. Quando as estratégias são eficazes, irão conduzir a bem-estar no trabalho. Se as estratégias não são eficazes, conduzem a representações de mal-estar e consequentemente a risco de adoecimento.

Ressalta-se que esses fatores se inscrevem em uma cultura organizacional que é transversal aos elementos que estruturam os contextos laborais e sua análise deve perpassar a investigação em qualidade de vida no trabalho. Integram a cultura organizacional a percepção comum que trabalhadores têm sobre valores, histórias, ritos, símbolos materiais, linguagem, comportamentos e crenças, entre outros aspectos (Robbins, 2010).

No nível microergonômico de QVT, O método de análise proposto é a Análise Ergonômica do Trabalho (AET), na qual a âncora teórica é a Ergonomia da Atividade (Guérin et al., 2001; Wisner, 2004), cujos traços centrais encontram-se descritos no artigo intitulado "Reconversão Tecnológica e Qualidade de Vida no Trabalho (QVT): Caso de Empresa Pública Brasileira". A Figura 3 demonstra o trajeto metodológico percorrido na realização da segunda etapa da pesquisa.

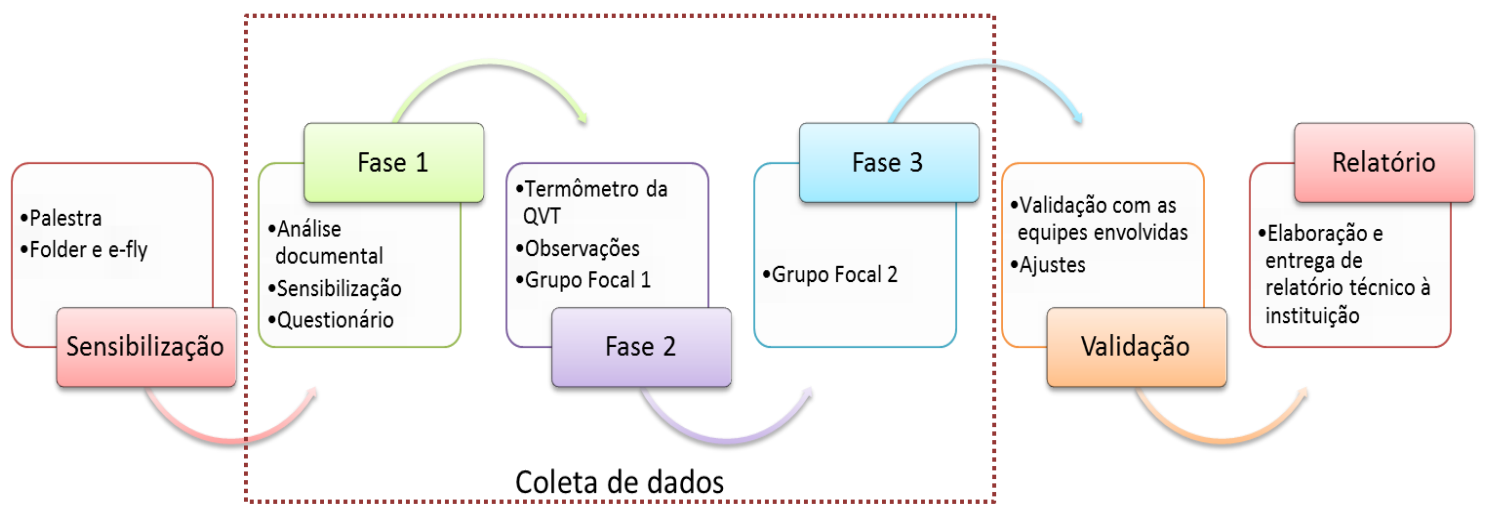

Figura 3. Trajeto metodológico da Etapa 2.

Um número significativo de pesquisas tem sido realizado no âmbito do ErgoPublic, e os resultados encontrados têm mostrado a pertinência e a coerência do modelo. Ademais, têm oportunizado às instituições onde as intervenções foram realizadas a construção de políticas e programas de qualidade de vida no trabalho. No poder judiciário, destacam-se as pesquisas realizadas por Andrade (2011) e Maia (2014). No poder executivo, as pesquisas de Albuquerque (2011), Daniel (2012) e Branquinho (2010). Já os estudos de Medeiros (2012), Figueira (2013) e Santos (2014) são referências de aplicação da abordagem nos dois níveis analíticos.

O conceito de QVT adotado nesta pesquisa é o de Ferreira (2012):

Sob a ótica das organizações, a QVT é um preceito de gestão organizacional que se expressa por um conjunto de normas, diretrizes e práticas no âmbito das condições, da organização e das relações socioprofissionais de trabalho que visa à promoção do bem-estar individual e coletivo, o desenvolvimento pessoal dos trabalhadores e o exercício da cidadania organizacional nos 
ambientes de trabalho. Sob a ótica dos trabalhadores, ela se expressa por meio das representações globais (contexto organizacional) e específicas (situações de trabalho) que estes constroem, indicando o predomínio de experiências de bem-estar no trabalho, de reconhecimentos institucional e coletivo, de possibilidade de crescimento profissional e de respeito às características individuais (Ferreira, 2012, p.172).

É papel da pesquisa descobrir e expressar relações que possam existir entre fenômenos ou variáveis. A hipótese tem a função de relacionar duas ou mais variáveis do problema de pesquisa, consistindo em uma suposição verossímil, que depois da análise dos fatos será comprovada ou negada. A hipótese pode ser compreendida ainda como "a suposição de uma causa ou de uma lei destinada a explicar provisoriamente um fenômeno até que os fatos a venham contradizer ou ratificar" (Cervo, Bervian \& Silva, 2007, p. 77).

Viegas (1999) afirma que a hipótese é um termo de uso variado, como por exemplo, na geometria e na gnosiologia, o que torna necessário precisar o sentido empregado na pesquisa científica. Nesta, a hipótese é uma afirmação que estabelece a relação entre variáveis a ser submetida à comprovação. Segundo o autor, são funções das hipóteses: servir de guia para a pesquisa; desencadear inferências; avaliar experimentos; e generalizar a experiência.

Nesta pesquisa a hipótese é classificada como descritiva. Hipóteses descritivas "(...) são proposições que normalmente declaram existência, tamanho, forma ou distribuição de alguma variável" (Cooper \& Schindler, 2003, p. 58). A hipótese global descritiva do presente estudo, transversal aos três artigos apresentados, é a seguinte:

As características do contexto de trabalho, em especial, da organização do trabalho e das práticas de reconhecimento e crescimento profissional, associadas às práticas de gestão e aos sentimentos dos trabalhadores em relação ao trabalho configuram um perfil complexo de Custo Humano do Trabalho (físico, cognitivo e afetivo) que obstaculiza a construção de estratégias operatórias de mediação individual e coletiva para a operacionalização das prescrições do trabalho e potencializa vivências de mal-estar no trabalho colocando em risco a qualidade de vida no trabalho desses trabalhadores.

Por fim, compõe este documento a conclusão geral, que sumariza os principais achados do estudo e aponta os limites e contribuições da pesquisa. 
 \\ DIMENSÕES ESTRUTURANTES DA PERCEPÇÃO DE \\ QUALIDADE DE VIDA NO TRABALHO (QVT): \\ ESTUDO DE CASO EM EMPRESA \\ PÚBLICA BRASILEIRA}

Veruska Albuquerque Pacheco

RESUMO

As constantes mudanças pelas quais o mundo do trabalho tem passado vêm impactando drasticamente as organizações o que tem levado ao aumento de estudos e intervenções em Qualidade de Vida no Trabalho (QVT). O tema, apesar de ser discutido há algumas décadas, permanece cada vez mais atual na academia e nas organizações. Nessa perspectiva, a presente pesquisa mapeou as representações de trabalhadores de uma empresa pública brasileira sobre os fatores estruturantes de QVT. A abordagem teórico-metodológica fundamentou-se na Ergonomia da Atividade Aplicada à Qualidade de Vida no Trabalho (EAA_QVT). O instrumento utilizado foi o Inventário de Avaliação de Qualidade de Vida no Trabalho (IA_QVT). Participaram 5.833 pessoas, correspondendo a 47,2\% do coletivo de empregados de uma empresa brasileira de tecnologia da informação. A análise mostrou que a percepção global dos trabalhadores de QVT é de bem-estar moderado com média de 6,47. Os fatores considerados mais críticos foram "Organização do Trabalho" (média 5,91) e "Reconhecimento e Crescimento Profissional" (média $5,74)$. Os resultados convergem com outros achados na literatura, apontando pistas para investigações futuras, além de fornecer subsídios à construção de programa e de política de QVT na instituição.

\section{ABSTRACT}

The constant changes the world of work has passed are dramatically impacting organizations which has led to increased research and intervention on Quality of Work Life (QWT). Despite being discussed for decades, the issue remains increasingly present in academia and organizations. In this perspective, the current research has mapped the representations of employees of a Brazilian public company on the structural factors of QWL. The theoretical and methodological framework was based on Activity Ergonomics Applied to Quality of Work Life (AEA_QWL). The instrument used was the Evaluation Inventory of Quality of Work Life (EI_QWL). 5,833 people participated, corresponding to $47.2 \%$ of the group of employees in a Brazilian company of information technology. The analysis showed that the overall perception of QWL workers is a moderate well-being with an average of 6.47. Most critical factors were "Work Organization" (average 5.91) and "Professional Recognition and Growth" (average 5.74). The results converge with other published studies, indicating clues for further research, in addition to providing data for the construction of QWL program and policy at the institution.

\section{RESUMEN}

Los cambios constantes que el mundo del trabajo ha sufrido afectan drásticamente las organizaciones lo que ha llevado a un aumento de la investigación y la intervención de Calidad de Vida en el Trabajo (CVT). El tema, a pesar de ser discutido hace algunas décadas, sigue cada vez más presente en el mundo académico y las organizaciones. En esta perspectiva, esta investigación ha trazado las representaciones de los empleados de una empresa pública brasileña en los factores estructurales de la CVL. El enfoque teórico y metodológico se basó en Ergonomía de la Actividad Aplicada a la Calidad de Vida en el Trabajo (EAA_CVT). El instrumento utilizado fue el Inventario de Evaluación de Calidad de Vida en el Trabajo (IE_CVT). 5.833 personas participaron, lo que representa el 47,2\% del grupo de empleados de una empresa brasileña de tecnología de la información. El análisis mostró que la percepción global de los trabajadores acerca de la CVT es el bienestar moderado con un promedio de 6.47. Los factores considerados más críticos fueron "Organización del trabajo" (promedio 5,91) y "Reconocimiento y Crecimiento Profesional" (promedio 5,74). Los resultados convergen con otros hallazgos en la literatura, señalando para futuras investigaciones, además de proporcionar datos para la construcción de programas y políticas de CVT en la institución.

\section{PALAVRAS-CHAVE:}

Qualidade de vida no trabalho; ergonomia da atividade; empresa pública brasileira.

KEYWORDS:

Quality f work life; activity ergonomics; brazilian public company.

\section{PALABLAS CLAVE:}

Calidad de vida en el trabajo; ergonomía de la actividad; empresa pública brasileña. 


\section{INTRODUÇÃO}

Cada vez mais a temática Qualidade de Vida no Trabalho (QVT) tem sido objeto de estudos na academia, bem como projeto de intervenções nos contextos laborais. A perspectiva e o interesse crescente que alimenta a discussão sobre QVT é de enfrentar os efeitos negativos sobre os trabalhadores e as organizações que são causados pelos processos de mudança decorrentes da reestruturação produtiva, marco da formação de uma nova configuração econômica, social e política que se contrapôs ao modelo taylorista/fordista hegemônico entre os anos de 1965 a 1975.

Uma das principais consequências para os trabalhadores nessa nova configuração foi a intensificação do trabalho. Novas tecnologias, busca incessante e obstinada por performance e produtividade, maior flexibilidade nos processos produtivos e capacidade de resiliência dos trabalhadores são alguns efeitos negativos nesse cenário atual, que vêm se produzindo nos setores privado e público, contribuindo também para configurar um quadro de precarização do trabalho (Antunes, 2008). No serviço público, a transposição mecânica da lógica produtivista, típica da cultura organizacional da gestão do trabalho na iniciativa privada, parece se reproduzir de forma equivocada, já que "produto" final do setor público é a promoção da cidadania. Por essa razão, a lógica gerencial que norteia as práticas organizacionais neste setor não deveria ser a mesma. Algumas resultantes dessa transposição merecem destaque: na perspectiva das organizações públicas, vê-se aumento de erros, retrabalho, queda de produtividade etc.; na perspectiva dos trabalhadores, têm-se o aumento das doenças laborais, absenteísmo, rotatividade, entre outros. E do ponto de vista dos usuários, queixas, reclamações, e, principalmente, a cidadania em risco (Ferreira, 2008a, 2012).

Diante de um cenário tão complexo cujos impactos têm sido extremamente negativos tanto para as organizações quanto para os trabalhadores, torna-se pertinente a realização de diagnósticos de QVT nas instituições para identificar aspectos que podem estar promovendo vivências de mal-estar e de bem-estar no trabalho, e consequentemente impactando positiva ou negativamente na QVT dos trabalhadores. Nesse sentido, o objetivo desta pesquisa foi identificar as representações de trabalhadores de uma empresa pública brasileira sobre os fatores estruturantes de qualidade de vida no trabalho.

Do ponto de visa social, estudos dessa natureza são relevantes, considerando que a cada dia mais trabalhadores adoecem e, em casos extremos morrem, em decorrência das enfermidades relacionadas ao trabalho. Segundo estima a OIT (2013), doenças profissionais estão entre as principais causas de mortes relacionadas ao trabalho, com uma alarmante média de 5.500 mortes diariamente (OIT, 2013). Ademais, tornamse relevantes em função da atualidade da discussão do tema no mundo do trabalho, cada dia mais complexo e mais desafiador. Na perspectiva das corporações, a aplicabilidade da pesquisa, que permite mapear a percepção dos trabalhadores sobre sua qualidade de vida no trabalho, pode subsidiar a construção de programas e políticas de QVT para as instituições. Por fim, no campo acadêmico, o estudo, em voga nas agendas de pesquisas nacionais e internacionais, permitirá avançar no processo de aplicação e consolidação da 
abordagem teórico-metodológica da Ergonomia da Atividade Aplicada à Qualidade de Vida no Trabalho (EAA_QVT), enfoque adotado na pesquisa.

Tendo em vista estudos já realizados no âmbito da EAA_QVT, a hipótese global delineada, descritiva (Amalberti, Montmollin, \& Thereau, 1991; Cooper \& Schindler, 2003), é de que a avaliação de QVT é globalmente positiva e que os fatores "Organização do Trabalho" e "Reconhecimento e Crescimento Profissional" são identificados como os mais críticos na percepção dos trabalhadores.

\section{Qualidade de Vida no Trabalho (QVT)}

Embora a temática QVT venha sendo investigada e debatida há aproximadamente quatro décadas (Ferreira, 2012; Martel \& Dupuis, 2006; Hackman e Oldham, 1975; Walton, 1973), ainda não há consenso entre autores quanto ao seu conceito (Bragard, Dupuis, Razavi, Reynaert \& Etienne, 2012; Brunalt, Fouquereau, Colombat, Gillet, El-Hage, Camus \& Gaillard, 2013; Ferreira, 2012; Ferreira, Alves \& Tostes, 2009; Fernandes, 1996; Josiah, Odera, Chepkuto \& Okaka, 2012; Lacaz, 2000; Lawler, 1982; Nadler \& Lawler, 1983; Nayeri, Salehi \& Noghabi, 2011; Tolfo, Silva \& Luna, 2009; Sampaio, 2012).

A miríade de conceitos apontados na literatura mostra a sua elasticidade e abrangência. Trata-se de um constructo subjetivo, dinâmico e multifacetado (Ahmad, 2013; Josiah et al., 2012; Lee et al., 2013; Martel \& Dupuis, 2006; Medeiros \& Ferreira, 2011). Por essa razão, trata-se de um constructo complexo, com muitas possibilidades de investigação.

Um marco para o surgimento do interesse sobre a QVT foi o final da $1^{\text {a }}$ Guerra Mundial, quando profundos impactos econômicos e sociais levaram a mudanças nas relações de trabalho. Diante desse contexto, àquele momento, discutir qualidade de vida no trabalho se restringia à questões econômicas, para mitigar os efeitos citados (Ferreira, 2008a; Albuquerque, 2011).

As mudanças que vêm ocorrendo no mundo do trabalho nas últimas décadas também são apontadas como causa para o crescente interesse de pesquisadores sobre a temática (Brunault et al., 2013; Zhao, Sun, Cao, Li, Duan, Fan \& Liu, 2012; Ferreira, 2008a), especialmente após o advento da chamada reestruturação produtiva, que vem deixando profundos impactos na economia mundial, e consequentemente nas organizações. São traços centrais desse fenômeno: redução do papel do Estado; políticas de valorização governamental do capital financeiro; contratos de trabalho flexíveis; aumento do desemprego; exclusão social; e baixa e instável expansão da riqueza da sociedade, flexibilização do processo produtivo, precarização (Leite, 1994; Ouriveis, 2013).

Os estudos em QVT tiveram início na década de 1950 no Tavistock Institute of Human Relations com Eric Trist e colaboradores, cujo foco dos pesquisadores, no modelo então proposto, centrava-se na satisfação dos trabalhadores e na análise da relação entre organização, trabalho e indivíduo (Rodrigues, 2011). Entretanto, as pesquisas em QVT tiveram impulso com base nas investigações de Walton (1973). O autor propôs em sua abordagem a discussão sobre o equilíbrio entre as esferas pessoal e profissional e sobre o papel social da organização. O modelo de QVT de Walton, ainda bastante utilizado e referenciado na literatura, 
é composto por oito fatores: compensação justa e adequada; condições de trabalho; uso e desenvolvimento de capacidades; oportunidade de crescimento e segurança; integração social na organização; constitucionalismo; trabalho e espaço total de vida; relevância social do trabalho na vida.

O modelo defendido por Hackman e Oldham (1975) preconiza a humanização do enfoque gerencial discutindo fatores de motivação interna. Segundo esses autores, há três estados psicológicos críticos que influenciam na motivação nos contextos laborais: conhecimentos e resultados do seu trabalho; responsabilidade percebida pelos resultados do seu trabalho; e significância percebida do seu trabalho. De acordo com este enfoque, as dimensões da tarefa incluem a variedade de habilidades, a identidade da tarefa, o significado da tarefa, a autonomia, o feedback extrínseco, o feedback do próprio trabalho e o interrelacionamento (Hackman e Oldham, 1975; Pedroso, Pillati, Santos \& Santos Júnior, 2010).

No modelo de QVT proposto por Werther \& Davis (1983) são delimitados elementos organizacionais, ambientais e comportamentais como aspectos que influenciam o projeto de cargos em termos de qualidade de vida no trabalho. Os elementos organizacionais incluem o fluxo de trabalho, a abordagem mecanicista e as práticas de trabalho. Os elementos ambientais abrangem as habilidades e disponibilidade de empregados e suas expectativas sociais. Os elementos comportamentais referem-se à autonomia, à variedade e identidade com a tarefa e à retroinformação.

Já a abordagem de qualidade de vida no trabalho delineada por Westley (1979), da escola sociotécnica, propõe um modelo composto por quatro dimensões que impactam na QVT: insegurança (instabilidade no emprego), injustiça (desigualdade social), alienação (baixa auto-estima) e anomia (carência de legislação trabalhista). A humanização dos postos de trabalho é elementochave neste modelo e permite minimizar as quatro problemáticas apontadas nas dimensões e promover qualidade de vida no trabalho (Pedroso \& Pillati, 2010).

Após o mapeamento dos principais modelos apontados na literatura, percebe-se que o conceito passou por várias visões ou fases evolutivas ao longo do tempo. Nadler e Lawler (1983) descreveram esse percurso, indicando as características ou visões acerca da QVT em cada fase. De acordo com os autores, a QVT passou pelas seguintes concepções evolutivas: a) QVT como variável (1959-1972); b) QVT como abordagem (1969-1974); c) QVT como método (1972-1975); d) QVT como movimento (1975-1980); e) QVT como tudo (1979-1982); e f) QVT como nada (futuro).

Analisando o que propõem os autores, a qualidade de vida no trabalho parece estar entre o que os mesmos denominaram "QVT como tudo" e "QVT como nada". Entretanto, com o fortalecimento de teorias e modelos, é possível depreender que a temática, pelo menos no momento atual, tende a se consolidar e não se transformar em mais um modismo.

Como já argumentado, o conceito de QVT abarca um conjunto de perspectivas bastante variado. A seguir, são apresentadas as perspectivas de alguns autores sobre a conceituação do construto.

Li e Yeo (2011) afirmam que QVT envolve bem-estar dos empregados, percepção de trabalho 
gratificante, percepção de dever cumprido, sem estresse e que dê satisfação. Fernandes (1996) afirma que QVT refere-se a uma gestão dinâmica e contingencial de fatores físicos, tecnológicos e sócio-psicológicos que afetam a cultura e renovam o clima organizacional, refletindo-se no bem-estar do trabalhador e na produtividade das empresas.

Limongi-França (2004; 2013) conceitua QVT em uma perspectiva biopsicossocial, como a percepção de bem-estar pessoal e as escolhas de bem-estar que compõem as políticas, as práticas e os serviços de gestão de pessoas. Esse conjunto pode ser analisado à luz de quatro fatores: dimensões biológicas; dimensões psicológicas; dimensões sociais; e dimensões organizacionais. Segundo Huang, Lawler e Lei (2007) QVT envolve condições e ambientes de trabalho e de vida favoráveis, aspectos como o equilíbrio da família/ trabalho de vida, a auto-realização, a remuneração e o comportamento de supervisão. Para Brunault et al. (2013) o construto é entendido como o nível de percepção de eficácia em quatro domínios profissionais: físico, psicológico, social e cultural.

Fernandes (1996) aponta que muitas estratégias inadequadas de implantação do conceito geralmente são oportunistas e imediatistas, e não passam de modismos frequentemente experimentados. A autora afirma que a concepção de QVT se apoia em três elementos centrais: a) resolução de problemas envolvendo membros em todos os níveis da organização; b) reestruturação da natureza do trabalho; e c) melhorias no ambiente organizacional.

Percebe-se, com base na revisão da literatura, que os aspectos que compõem a concepção de QVT abrangem vários elementos, como saúde, segurança, relações de trabalho, estresse, humanização, entre outros. Globalmente, é possível identificar que os conceitos convergem para quatro eixos que norteiam a perspectiva dos autores pesquisados:

a) QVT e satisfação com o trabalho: Brunault et al., 2013; Lee et al., 2013; Marta et al., 2013; Sirgy et al. 2001; Tolfo, Silva \& Luna, 2009; Martel \& Dupuis, 2006; Zhao et al., 2012.

b) QVT e produtividade: Abarqhouei \& Nasab, 2011; Aketch et al., 2012; An, Yom \& Ruggiero, 2011; Josiah et al., 2012; Lawler, 1982; Nayeri, Salehi \& Noghabi, 2011.

c) QVT e bem-estar no trabalho: Ferreira, 2012; Li \& Yeo, 2011; Sampaio, 2012; Vasconcelos, 2001.

d) QVT e comprometimento: Huang et al., 2007; Koonmee, Singhapakdi, Virakul \& Lee, 2010; Zhao et al., 2012.

Para este trabalho, o conceito de QVT adotado é o de Ferreira (2012, p. 172), ancorado na abordagem teórico-metodológica denominada Ergonomia da Atividade Aplicada à Qualidade de Vida no Trabalho (EAA_QVT). Segundo o autor, o conceito engloba duas perspectivas interdependentes:

- Sob a ótica das organizações, a QVT é um preceito de gestão organizacional que se expressa por um conjunto de normas, diretrizes e práticas no âmbito das condições, da organização e das relações socioprofissionais de trabalho que visa a promoção do bem-estar individual e coletivo, o desenvolvimento pessoal dos trabalhadores e o exercício da cidadania organizacional nos ambientes de trabalho.

- Sob a ótica dos trabalhadores, ela se expressa por meio das representações globais (contexto organizacional) e específicas (situações de trabalho) que estes constroem, indicando o predomínio de experiências de bem-estar no trabalho, de reconhecimento institucional e coletivo, de possibilidade de crescimento profissional e de respeito às características individuais. 
Se apoiando na definição de QVT (Ferreira, 2012), Ferreira, Paschoal e Ferreira (2013) apresentam o modelo teórico da EAA_QVT (Figura 1), composto por dimensões analíticas e fatores

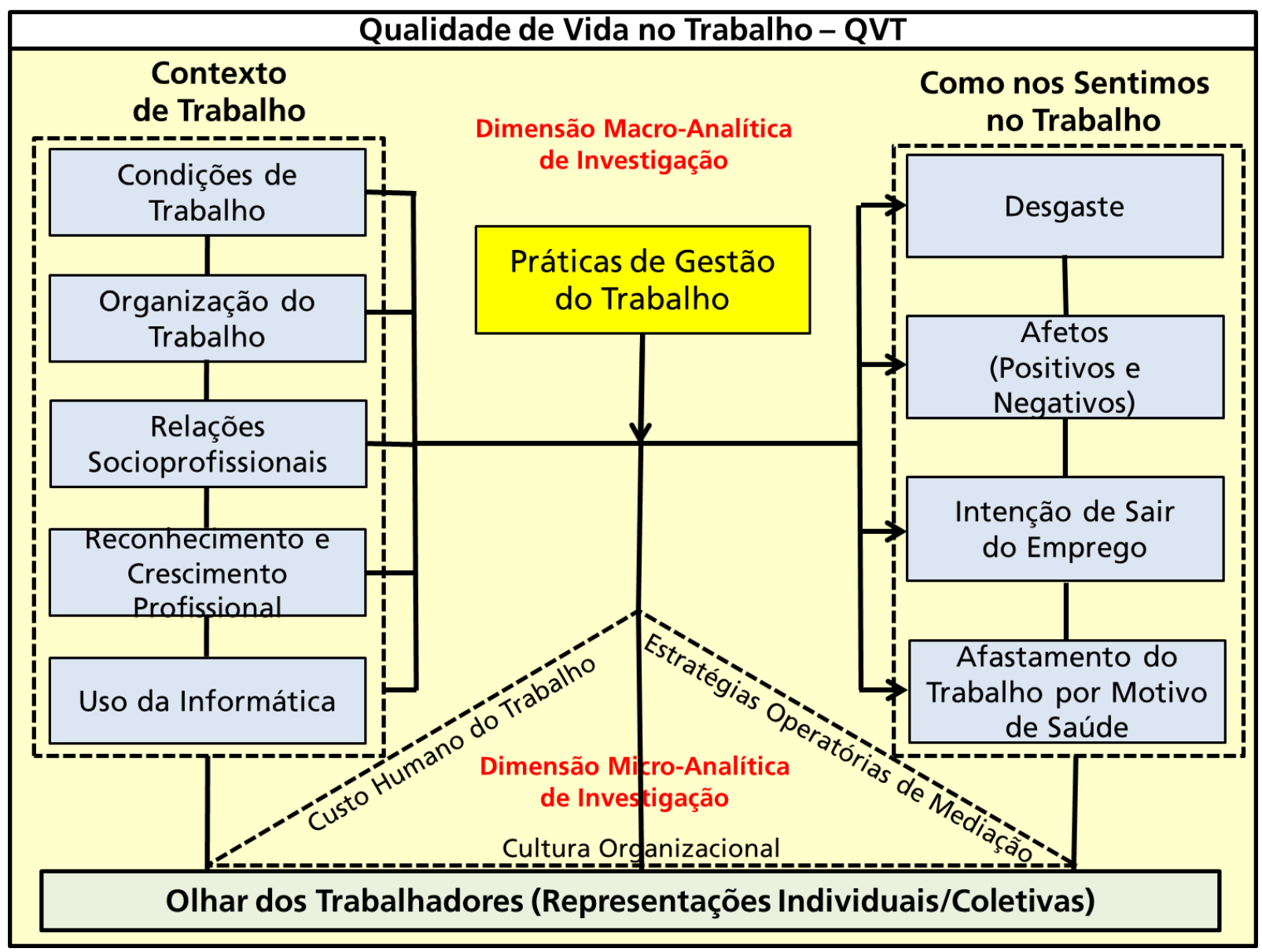

Figura 1. Modelo Teórico-Descritivo de Qualidade de Vida no Trabalho. Fonte: Ferreira, Paschoal e Ferreira (2013).

O modelo é composto por dois níveis analíticos interdependentes: o primeiro é denominado dimensão macro-analítica (ou macroergonômica) de investigação. O segundo é composto pela dimensão micro-analítica (ou microergonômica) de investigação.

De acordo com o modelo, a QVT nasce das representações individuais e coletivas dos trabalhadores com base em três eixos/fatores: "Contexto de Trabalho", "Práticas de Gestão" e "Como nos Sentimos no Trabalho". As variáveis constitutivas destes fatores encontram-se na seção de método.
O modelo proposto possui um delineamento correlacional, onde as variáveis do "Contexto de Trabalho" são antecedentes e as variáveis referentes aos "Sentimentos no Trabalho" são consequentes. As "Práticas de Gestão" neste enfoque teórico são, portanto, moderadoras das relações entre os dois eixos.

\section{MÉTODO}

Trata-se, neste estudo, de pesquisa de natureza empírica (Demo, 2011), de caráter quantitativo e caracterizada como estudo de caso (Cervo, Bervian e Silva, 2007; Gil, 2009). Realizou-se 
a pesquisa em uma empresa pública brasileira, cuja missão é disponibilizar informações e prover soluções tecnológicas para o êxito da gestão do Estado em atendimento à sociedade brasileira. Sua visão preconiza ser um centro de informações e soluções tecnológicas para o Brasil.

Segundo Gil (2009), o estudo de caso caracteriza-se pela preservação do caráter unitário do fenômeno sem separá-lo do seu contexto, investigando-o in loco, com profundidade. 0 método permite, ainda, a utilização de múltiplos procedimentos de coleta de dados. Por sua vez, a pesquisa quantitativa, em estudos organizacionais, "permite a mensuração de opiniões, reações, hábitos e atitudes em um universo, por meio de uma amostra que o represente estatisticamente" (Terrence \& Filho, 2006, p. 3).

\section{Participantes}

À época da coleta, a empresa tinha em seu quadro funcional 12.357 empregados. Destes, 7.677 fazem parte do quadro interno, enquanto os demais compõem o pessoal de serviço externo. Participaram da pesquisa 5.833 pessoas, correspondendo a $47,2 \%$ do coletivo de empregados. Do total de empregados do quadro interno, participaram 4.065 respondentes (47,2\%). Este é um dado que demonstra a efetividade das atividades de sensibilização realizadas na condução do projeto de pesquisa, que garantiram uma participação significativa dos empregados. O perfil sociodemográfico e profissiográfico dos participantes (n válidos totais = 4.436) é demonstrado na tabela 1.

Tabela 1

Resumo do perfil sociodemográfico e profissiográfico dos participantes

\begin{tabular}{|c|c|c|c|c|c|c|c|c|}
\hline \multicolumn{9}{|c|}{ Dados Sociodemográficos } \\
\hline \multirow{2}{*}{ Idade } & $\mathrm{N}$ & \multicolumn{3}{|c|}{ Média } & \multicolumn{4}{|c|}{ DP } \\
\hline & 5.260 & \multicolumn{3}{|c|}{46,75} & \multicolumn{4}{|c|}{11,61} \\
\hline \multirow{2}{*}{ Gênero } & $\mathrm{N}$ & \multirow{2}{*}{\multicolumn{3}{|c|}{ Masculino }} & \multicolumn{4}{|c|}{ Feminino } \\
\hline & 5.391 & & & & \multicolumn{4}{|c|}{$2.038(38 \%)$} \\
\hline \multirow[b]{2}{*}{ Estado Civil } & $\mathrm{N}$ & Casado & Solteiro & \multicolumn{2}{|c|}{ Divord/ Separ } & Outros & \multicolumn{2}{|c|}{ Viúvo } \\
\hline & 5.418 & $3.182(58,7 \%)$ & $\begin{array}{c}1.524 \\
(28,1 \%)\end{array}$ & \multicolumn{2}{|c|}{$498(9,2 \%)$} & $\begin{array}{c}151 \\
(2,8 \%) \\
\end{array}$ & \multicolumn{2}{|c|}{$63(1,2 \%)$} \\
\hline \multirow{2}{*}{ Escolaridade } & $\mathrm{N}$ & Fund. & \multicolumn{2}{|c|}{ Médio } & \multicolumn{2}{|c|}{ Superior } & \multicolumn{2}{|c|}{ Pós-Grad. } \\
\hline & 5.426 & 350 & \multicolumn{2}{|c|}{1.379} & \multicolumn{2}{|c|}{1.963} & \multicolumn{2}{|c|}{1.734} \\
\hline \multicolumn{9}{|c|}{ Dados profissiográficos } \\
\hline \multirow[b]{2}{*}{ Cargo* } & $\mathrm{N}$ & NA & $A X$ & \multicolumn{2}{|l|}{ TE } & TR & AP & ES \\
\hline & 5.009 & $\begin{array}{c}2.527 \\
(50,4 \%)\end{array}$ & $\begin{array}{c}1.085 \\
(21,7 \%)\end{array}$ & \multicolumn{2}{|c|}{$1.005(20,1 \%)$} & $\begin{array}{c}298 \\
(5,9 \%)\end{array}$ & $62(1,2 \%)$ & $\begin{array}{c}32 \\
(0,6 \%)\end{array}$ \\
\hline \multirow{2}{*}{ Forma de Admissāo } & $\mathrm{N}$ & \multicolumn{2}{|c|}{ Concurso Público } & \multicolumn{3}{|c|}{ Processo Seletivo } & \multicolumn{2}{|c|}{ Nomeaçāo } \\
\hline & 4.498 & \multicolumn{2}{|c|}{$2.378(52,9 \%)$} & \multicolumn{3}{|c|}{$2.093(46,5 \%)$} & \multicolumn{2}{|c|}{$27(0,6 \%)$} \\
\hline & $\mathrm{N}$ & & Média & & & & DP & \\
\hline Iempo de Serviço (anos) & 5.299 & & 16,49 & & & & 12,96 & \\
\hline Tomnn na lotacōo (annc) & $\mathrm{N}$ & & Média & & & & DP & \\
\hline Tempo ild Lutaçau (dmus) & 4.481 & & 8,68 & & & & 8,88 & \\
\hline & $\mathrm{N}$ & Dir. 1 & Dir. 2 & Dir. 3 & & r. 4 & Dir. 5 & Dir. 6 \\
\hline Diretoria** & 3.855 & $\begin{array}{l}1.387 \\
(36 \%)\end{array}$ & $\begin{array}{c}1.300 \\
(33,7 \%)\end{array}$ & $\begin{array}{c}491 \\
(12,7 \%)\end{array}$ & & $\begin{array}{l}09 \\
6 \%)\end{array}$ & $187(4,9 \%)$ & $81(2,1 \%)$ \\
\hline
\end{tabular}

* AN: Analista; AX: Auxiliar; TE: Técnico; TR: Terceirizado; AP: Jovem Aprendiz; ES: Estagiário.

** Os nomes das diretorias foram modificados para preservar a confidencialidade da organização.

\section{Instrumento}

Utilizou-se o Inventário de Avaliação de Qualidade de Vida no Trabalho - IA_QVT, versão
2.0. O IA_QVT é um instrumento quanti-qualitativo que possibilita o diagnóstico e o mapeamento de QVT em contextos organizacionais com base na percepção dos trabalhadores. 


\section{Dimensões Estruturantes da Percepção de Qualidade}

de Vida no Trabalho (QVT): Estudo de Caso em

Empresa Pública Brasileira

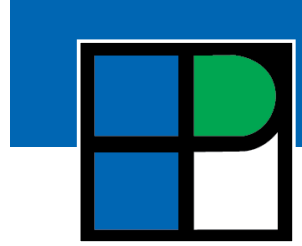

Grupo de Estudos Pesquisas em

O IA_QVT, em sua parte quantitativa, é do tipo Likert com 11 pontos, variando de composto por três escalas: "Contexto de Trabalho", $0=$ Discordo Totalmente a 10=Concordo Totalmente. "Práticas de Gestão" e "Impactos do Trabalho". A Figura 2 ilustra a cartografia do IA_QVT.

Trata-se de escalas psicométricas de concordância

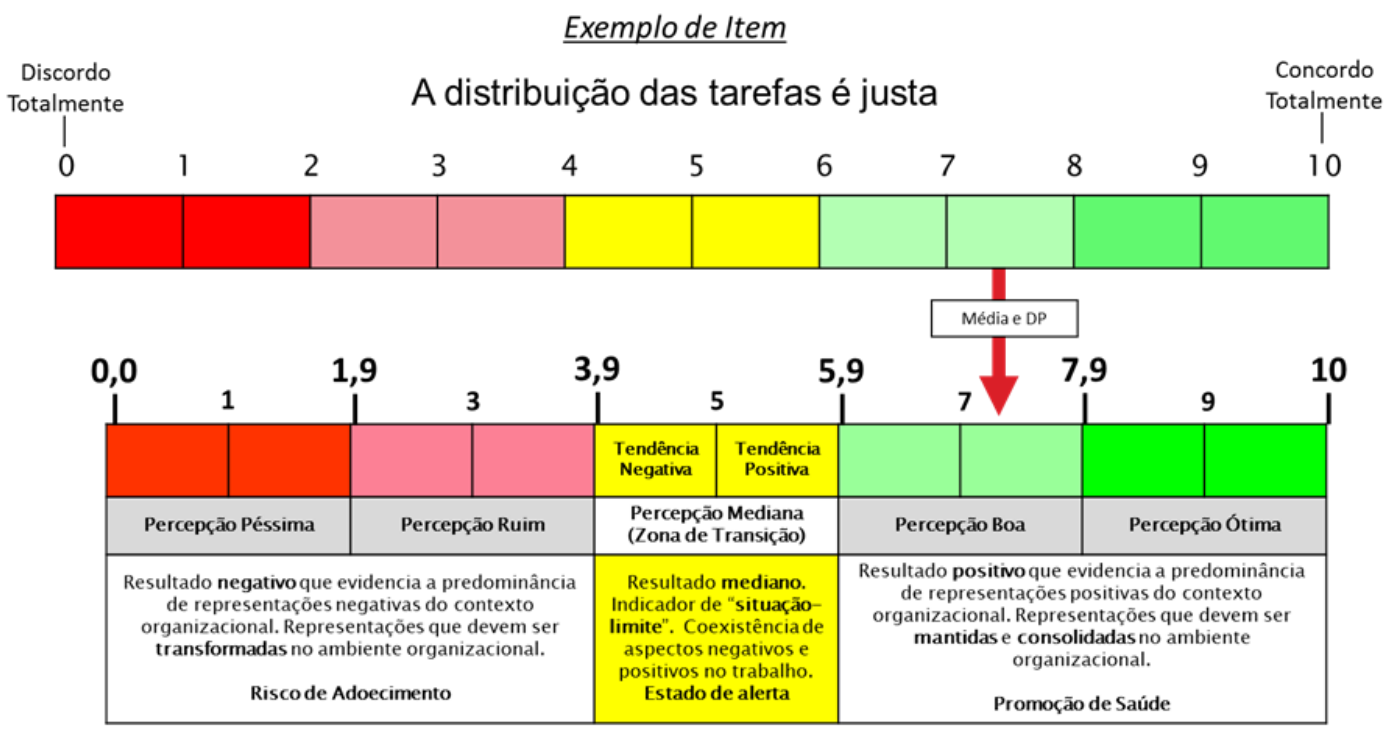

Figura 2. Cartografia psicométrica do IA_QVT. Fonte: Ferreira (2012).

A escala "Contexto de Trabalho", composta

As descrições, alfas de Cronbach e número de por 34 itens, avalia as representações dos respondentes relativas à qualidade de vida no Tabela 2 .

trabalho com base em cinco dimensões ou fatores.

Tabela 2

Fatores do IA_QVT na escala "Contexto de Trabalho".

\begin{tabular}{l|l|c|c}
\hline \multicolumn{1}{c|}{ Fator } & \multicolumn{1}{|c|}{ Descriçāo } & $\begin{array}{c}\text { Alfa de } \\
\text { Cronbach }\end{array}$ & $\begin{array}{c}\mathrm{N}^{\circ} \text { de } \\
\text { Itens }\end{array}$ \\
\hline Condiçōes de Trabalho & $\begin{array}{l}\text { Suporte instrumental (espaço físico, iluminaçāo, mobiliário, } \\
\text { posto de trabalho) disponibilizado no contexto } \\
\text { organizacional. }\end{array}$ & 0,89 & 5 \\
\hline Organizaçāo do Trabalho & $\begin{array}{l}\text { Carga, pressāo, tempo (pausa, execuçāo com zelo) e à } \\
\text { cobrança presentes no contexto organizacional. }\end{array}$ & 0,81 & 5 \\
\hline $\begin{array}{l}\text { Relaçōes Socioprofissionais de } \\
\text { Trabalho }\end{array}$ & $\begin{array}{l}\text { Interaçōes socioprofissionais concernentes à convivência, à } \\
\text { confiança, ao acesso às chefias, à comunicaçāo e à justiça na } \\
\text { distribuiçāo de tarefas. }\end{array}$ & 0,86 & 5 \\
\hline $\begin{array}{l}\text { Reconhecimento e Crescimento } \\
\text { Profissional }\end{array}$ & $\begin{array}{l}\text { Oportunidades, reconhecimento dos resultados do trabalho, } \\
\text { criatividade, reconhecimento social, incentivos das chefias e } \\
\text { prazer no trabalho. }\end{array}$ & 0,92 & 6 \\
\hline Uso da Informática & $\begin{array}{l}\text { Qualidade, disponibilidade, funcionamento e adequabilidade } \\
\text { do suporte de informática disponibilizado no contexto } \\
\text { organizacional. }\end{array}$ & 0,86 & 13 \\
\hline
\end{tabular}

A escala "Práticas de Gestão", composta por

A escala "Impactos do Trabalho", com 27 6 itens, permite avaliar as representações dos itens, avalia as representações relativas às respondentes relativas ao modo de gestão habitual existente no contexto organizacional. O Alfa de Cronbach é de 0,74. experiências, às emoções, aos afetos e ao desgaste individual no contexto de trabalho, com base em três dimensões descritas com seus alfas correspondentes na Tabela 3. 
Tabela 3

Fatores do IA_QVT na escala "Impactos do Trabalho".

\begin{tabular}{l|l|c|c}
\hline \multicolumn{1}{c|}{ Fator } & \multicolumn{1}{|c|}{ Descriçāo } & $\begin{array}{c}\text { Alfa de } \\
\text { Cronbach }\end{array}$ & $\begin{array}{c}\mathrm{N}^{\circ} \text { de } \\
\text { Itens }\end{array}$ \\
\hline $\begin{array}{l}\text { Desgaste Proveniente do } \\
\text { Trabalho }\end{array}$ & $\begin{array}{l}\text { Esgotamento pessoal, cansaço, tempo livre, capacidade de } \\
\text { trabalho e levar trabalho para casa. }\end{array}$ & 0,68 & 5 \\
\hline Afetos Positivos & $\begin{array}{l}\text { Emoçōes e humores positivos vivenciados no contexto de } \\
\text { trabalho. }\end{array}$ & 0,95 & 9 \\
\hline Afetos Negativos & $\begin{array}{l}\text { Emoçōes e humores negativos vivenciados no contexto de } \\
\text { trabalho. }\end{array}$ & 0,94 & 13 \\
\hline
\end{tabular}

\section{Procedimentos de coleta}

Para proceder à coleta, realizaram-se estratégias de sensibilização diversas, como por exemplo a apresentação de palestras, a distribuição de folders e o encaminhamento de e-flyers. Em pesquisas dessa natureza, a sensibilização tem um papel primordial, pois permite que os respondentes compreendam o objetivo da pesquisa, os preceitos éticos que a norteiam e recebam informações sobre o instrumento de coleta e sobre a devolutiva dos resultados.

Aplicou-se o IA_QVT na versão digital, via internet. $\mathrm{O}$ instrumento ficou hospedado em sítio externo à empresa, para garantir a segurança das informações e aumentar a participação do públicoalvo e confiabilidade das respostas. Elaborou-se códigos de acesso em quantidade superior ao total de empregados, que foram distribuídos de forma aleatória.

Na tela inicial de acesso ao instrumento, foram apresentados aos participantes os aspectos éticos em relação à participação voluntária, à possibilidade de desistência de participação sem causar prejuízos ou danos pessoais, à ausência de riscos para as atividades ou para a instituição, ao sigilo dos dados e a garantia de anonimato, conforme preconiza a Resolução MS 196/96 do Conselho Nacional de Saúde. Somente após a leitura de tais diretrizes éticas da pesquisa na tela do aplicativo e o clique na opção "de acordo" (assinatura eletrônica) pelo participante é que era disponibilizado o campo no qual ele podia inserir o seu código pessoal e único de acesso ao conteúdo do IA_QVT.

\section{Procedimentos de Tratamento e Análise dos Dados}

Utilizaram-se os softwares Excel e o Pacote Estatístico para as Ciências Sociais (SPSS), versão 19.0 para o tratamento dos dados. Tal uso possibilitou gerar estatísticas descritivas (média, mediana, moda, desvio-padrão, variância, mínimo, máximo, amplitude, frequência e percentuais), e inferenciais (Teste $U$ de Mann-Whitney) para descrever e analisar as variáveis de perfil e a percepção de QVT dos respondentes. sujeitos. A opção pelo teste deu-se após realização de análise de pressupostos que levaram à constatação de não normalidade das variáveis. Os dados obtidos na parte quantitativa são interpretados à luz da cartografia psicométrica, apresentada na Figura 2.

\section{RESULTADOS}

O IA_QVT permite a análise dos resultados em três níveis analíticos: a) nota global de QVT; b) nota de cada uma das escalas e seus respetivos fatores; c) nota dos itens que compõem cada fator nas escalas. 
Apresentam-se a seguir os resultados quantitativos do instrumento de pesquisa, separados por cada escala do IA_QVT: "Nosso Contexto de Trabalho", "Nossas Práticas de Gestão" e "Como nos Sentimos no Trabalho".

\section{Escala 1 - Contexto de Trabalho}

Apresentam-se a seguir os resultados da Escala 1, que mapeia as percepções dos respondentes acerca do contexto de trabalho, incluindo os fatores "Condições de Trabalho", "Organização do Trabalho", "Relações
Socioprofissionais", "Reconhecimento e Crescimento Profissional" e "Uso da Informática".

\section{Percepção Global do Contexto de Trabalho}

A percepção global dos participantes $(\mathrm{N}=4.971)$ resultou em uma média de 6,47 (Contexto Bom), com desvio-padrão de 1,39. À luz da cartografia, verifica-se (Figura 3) que a empresa encontra-se globalmente em uma zona de bemestar moderado, já que 26,51\% dos participantes evidenciam representações positivas. Na zona de transição, que demonstra a coexistência de bem-
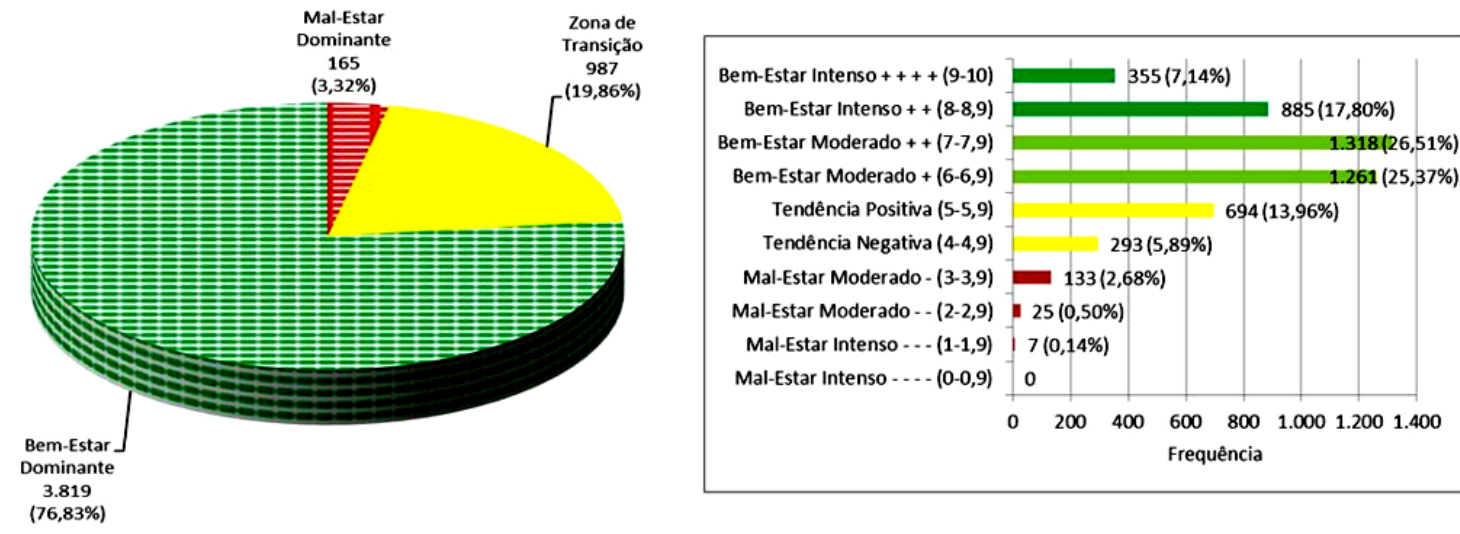

Figura 3. Nota global do eixo contexto de trabalho.

Contexto de Trabalho: Percepção do Fator Condições de Trabalho

O fator "Condições de trabalho" ( $N=5.568)$, composto por 5 itens, apresentou média igual a 7,4, (Contexto Bom) com desvio-padrão de 1,98, conforme pode se verificar na tabela 4. Ao observar os resultados, é possível notar que todos os itens localizaram-se na zona de bem-estar dominante, sendo que o item melhor avaliado refere-se à iluminação do ambiente (média 8,26; desvio-padrão 2,19), enquanto o item com menor média foi referente à adequação do mobiliário existente (média=6,90; desvio-padrão 3,01).

Tabela 4

Média dos itens que compōem o fator "Condiçōes de Trabalho"

\begin{tabular}{l|c}
\hline Item & Média \\
\hline O nível de iluminaçāo é suficiente para executar as atividades & 8,26 \\
\hline O espaço físico é satisfatório & 7,49 \\
\hline O posto de trabalho é adequado para a realizaçāo das tarefas & 7,34 \\
\hline Na empresa, as condiçōes de trabalho sāo satisfatórias & 7,03 \\
\hline O mobiliário existente no local de trabalho é adequado & 6,90 \\
\hline
\end{tabular}


Contexto de Trabalho: Percepção do Fator Organização do Trabalho

O fator "Organização do Trabalho" ( $\mathrm{N}=5.371)$, constituído de 5 itens, apresentou o resultado mais crítico do eixo "Nosso Contexto de Trabalho", resultando em uma média de 5,91, situando o fator em uma zona de transição de tendência positiva, conforme pode-se constatar na tabela 5. Aqui, o item que se destaca como mais crítico, situado em uma área de mal-estar dominante, refere-se à forte cobrança por resultados $(M=3,76 ; \quad D P=2,91)$. Na zona de transição, emergem questões sobre a pressão no trabalho e a falta de tempo para descanso no trabalho. Os demais itens, em zona de bem-estar dominante, caracterizam o contexto bom, no qual o tempo para executar o trabalho com zelo é visto de forma positiva $(M=7,48 ; D P=2,35)$.

Tabela 5

Média dos itens que compōem o fator "Organizaçāo do Trabalho"

\begin{tabular}{l|c}
\hline Item & Média \\
\hline Na empresa, disponho de tempo para executar o meu trabalho com zelo & 7,48 \\
\hline Posso executar o meu trabalho sem sobrecarga de tarefas & 6,27 \\
\hline Falta tempo para ter pausa de descanso no trabalho (INV) & 6,04 \\
\hline Posso executar o meu trabalho sem pressão & 6,03 \\
\hline Na empresa, existe forte cobrança por resultados (INV) & 3,76 \\
\hline
\end{tabular}

Contexto de Trabalho: Percepção do Fator Relações Socioprofissionais

No fator em questão, cujo conjunto de itens totaliza 5 e com $\mathrm{N}=5.375$, a percepção do grupo pesquisado situou-se na zona de bem-estar dominante, com média 6,89 e desvio-padrão de
1,78. A tabela 6 ilustra o resultado, cujo destaque mais positivo se relaciona ao fácil acesso à chefia imediata $(M=8,42 ; D P=2,24)$, enquanto a questão da comunicação entre funcionários se situou em zona de transição, com média de 5,46 e desviopadrão de 3,07.

Tabela 6

Média dos itens que compōem o fator "Relaçōes Socioprofissionais"

\begin{tabular}{l|c}
\hline Item & Média \\
\hline É fácil o acesso à chefia imediata & 8,42 \\
\hline A convivência no ambiente de trabalho é harmoniosa & 7,61 \\
\hline Há confiança entre os colegas & 6,83 \\
\hline A distribuiçāo das tarefas é justa & 6,17 \\
\hline A comunicação entre funcionários é insatisfatória (INV) & 5,46 \\
\hline
\end{tabular}

Contexto de Trabalho: Percepção do Fator Reconhecimento e Crescimento Profissional

O fator "Reconhecimento e Crescimento Profissional", composto por 6 itens, apresentou o segundo pior item do eixo "Nosso Contexto de Trabalho", com média de 5,74 e desvio-padrão 2,33, o colocando, na escala psicométrica, em um contexto mediano com tendência positiva. Neste fator (Tabela 7), 4 itens localizam-se em zona de transição, sendo que as oportunidades de crescimento profissional são apontadas como mais críticas, em tendência negativa, com média 4,47 e desvio-padrão 3,38. Na zona considerada como contexto bom, destaca-se a possibilidade de ser criativo no trabalho, com média 6,79 e desviopadrão 2,77. 
Tabela 7

Média dos itens que compōem o fator "Reconhecimento e Crescimento Profissional"

\begin{tabular}{l|c}
\hline Item & Média \\
\hline Tenho a possibilidade de ser criativo no meu trabalho & 6,79 \\
\hline Na empresa, as atividades que realizo sāo fonte de prazer & 6,64 \\
\hline Na empresa, recebo incentivos de minha chefia & 5,86 \\
\hline Na empresa, o resultado obtido com meu trabalho é reconhecido & 5,60 \\
\hline A sociedade reconhece a importância do meu trabalho & 5,17 \\
\hline A empresa oferece oportunidade de crescimento profissional & 4,47 \\
\hline
\end{tabular}

Contexto de Trabalho: Percepção do Fator Uso da Informática

O fator "Uso da Informática", composto por 13 itens, revelou média de 6,51, com desvio-padrão de 1,64. Na cartografia, esta média indica uma representação de bem-estar dominante. No que se refere a este fator, 3 itens situaram-se em uma zona de transição (Tabela 8): uso das mídias sociais como ferramentas colaborativas $(M=4,98 ; \quad D P=3,14)$; funcionamento dos aplicativos sem apresentar defeitos $(M=5,93 ; D P=3,03)$; e correio eletrônico como ferramenta para atender às necessidades de comunicação no trabalho $(M=5,60 ; D P=3,35)$. Em zona de bem-estar dominante, o item que recebeu melhor avaliação foi sobre a baixa frequência no recebimento de dados indesejados no sistema utilizado (M=7,58; $\mathrm{DP}=2,85)$.

Tabela 8

Média dos itens que compōem o fator "Uso da Informática"

\begin{tabular}{l|c}
\hline Item & Média \\
\hline O recebimento de dados indesejados (ex. spam) nāo é frequente no sistema que utilizo & 7,58 \\
\hline O funcionamento da rede elétrica contribui positivamente para o funcionamento da informática & 7,31 \\
\hline $\begin{array}{l}\text { Os equipamentos de informática (estaçāo de trabalho, impressora, servidores, etc) que uso sāo adequados } \\
\text { ao meu trabalho }\end{array}$ & 7,28 \\
\hline Nos sistemas que utilizo nāo é frequente a perda de dados/informaçōes & 7,25 \\
\hline O funcionamento da intranet no meu posto de trabalho é eficiente & 6,77 \\
\hline A conexāo com a internet no meu posto de trabalho é eficiente & 6,77 \\
\hline $\begin{array}{l}\text { Os sistemas de informaçāo da empresa disponibilizam as informaçōes de que necessito para a execução } \\
\text { de minhas tarefas }\end{array}$ & 6,67 \\
\hline O suporte técnico em informática na empresa é satisfatório & 6,44 \\
\hline Os sistemas que uso no dia-a-dia estāo sempre disponíveis & 6,43 \\
\hline $\begin{array}{l}\text { Os equipamentos de informática (estaçāo de trabalho, impressora, servidores, etc) que uso funcionam sem } \\
\text { apresentar defeitos }\end{array}$ & 6,04 \\
\hline $\begin{array}{l}\text { O correio eletrônico (email) que a empresa disponibiliza atende minhas necessidades de comunicaçāo no } \\
\text { trabalho }\end{array}$ & 5,60 \\
\hline Os aplicativos (softwares) que utilizo funcionam sem apresentar defeitos & 5,39 \\
\hline O uso das mídias sociais como ferramentas colaborativas é precário na empresa. (INV) & 4,98 \\
\hline
\end{tabular}

\section{Escala 2 - Práticas de Gestão}

O eixo que avalia as percepções sobre as "Práticas de Gestão" é composto de 6 itens, e apresentou média de 5,99, com desvio-padrão de 1,85. O item pior avaliado (Tabela 9), localizado em zona de mal-estar dominante, destaca o modo de gestão que supervaloriza a obediência à hierarquia $(M=3,41 ; D P=2,82)$. Em zona de bem-estar, o melhor item avaliado ressalta a liberdade de ação na execução das tarefas $(M=7,43 ; D P=2,47)$. 
Tabela 9

Média dos itens que compōem o eixo "Práticas de Gestāo"

\begin{tabular}{l|c}
\hline Item & Média \\
\hline Tenho liberdade de açāo na execuçāo das tarefas & 7,43 \\
\hline A chefia imediata demonstra interesse pela minha opiniāo & 6,71 \\
\hline O modo de gestāo das tarefas é flexível & 6,46 \\
\hline A cooperaçāo entre as pessoas é estimulada & 6,35 \\
\hline Participo das decisōes sobre a organizaçāo das tarefas & 5,59 \\
\hline O modo de gestāo supervaloriza a obediência à hierarquia (INV) & 3,41 \\
\hline
\end{tabular}

\section{Escala 3 - Sentimentos no Trabalho}

Nessa escala, cujos resultados estão descritos a seguir, são mapeadas as percepções dos trabalhadores acerca dos desgastes provenientes do trabalho, bem como os afetos positivos e negativos que impactam na atividade laboral.

\section{Percepção do Desgaste Proveniente do Trabalho}

O fator "Desgaste Proveniente do Trabalho" é constituído de 5 itens, e apresentou média global de
4,24, com desvio-padrão de 2,07, situando-se na zona de transição. Neste eixo, quanto maiores as médias, maior o desgaste do trabalhador. O item pior avaliado (desgaste alto) refere-se ao trabalho no limite das capacidades ( $M=6,37 ; D P=2,87)$, enquanto $O$ item melhor avaliado (desgaste baixíssimo) destaca a necessidade de se levar trabalho pra casa $(M=1,70 ; D P=2,51)$. A tabela 10 ilustra os resultados do fator.

Tabela 10

Média dos itens que compōem o fator "Desgaste Proveniente do Trabalho"

\begin{tabular}{l|c}
\hline Item & Média \\
\hline Após o expediente na empresa, é comum levar trabalho pra casa (INV) & 1,70 \\
\hline O trabalho prejudica o uso do meu tempo livre fora da empresa (INV) & 3,64 \\
\hline 0 trabalho tem me levado ao esgotamento profissional (INV) & 4,02 \\
\hline Tenho me sentido cansado (INV) & 5,47 \\
\hline Tenho trabalhado no limite de minha capacidade (INV) & 6,37 \\
\hline
\end{tabular}

\section{Percepção dos Afetos Positivos e Negativos}

No fator "Afetos Positivos", composto por 9 itens, a média foi de 5,54, com desvio-padrão de 2,56, situando-se em zona de transição de tendência positiva. O sentimento positivo pior avaliado foi a empolgação ( $M=4,94 ; \quad D P=3,06)$, enquanto o sentimento melhor avaliado foi a alegria $(M=5,98 ; D P=2,84)$. O fator "Afetos Negativos", formado por 13 itens, situou-se em zona de bem-estar dominante, com média global de 3,82 e desvio-padrão 2,50. Em zona de transição, com piores médias, destacam-se os sentimentos de preocupação $(M=5,24 ; \quad D P=3,20)$ e ansiedade $(M=4,56 ; \quad D P=3,23)$. O afeto melhor avaliado, localizado em zona de bem-estar dominante, foi o medo $(M=2,52 ; D P=3,20)$. A tabela 11 ilustra os resultados dos fatores. 
Tabela 11

Média dos itens que compōem os fatores "Afetos Positivos" e "Afetos Negativos"

\begin{tabular}{|c|c|}
\hline \multicolumn{2}{|c|}{ Afetos Negativos } \\
\hline Item & Média \\
\hline Com medo (INV) & 2,52 \\
\hline Com raiva (INV) & 2,79 \\
\hline Deprimido (INV) & 2,99 \\
\hline Nervoso (INV) & 3,55 \\
\hline Entediado (INV) & 3,73 \\
\hline Impaciente (INV) & 3,96 \\
\hline Chateado (INV) & 3,96 \\
\hline Tenso (INV) & 4,05 \\
\hline Irritado (INV) & 4,05 \\
\hline Frustrado (INV) & 4,13 \\
\hline Incomodado (INV) & 4,24 \\
\hline Ansioso (INV) & 4,56 \\
\hline Preocupado (INV) & 5,24 \\
\hline
\end{tabular}

\begin{tabular}{l|c} 
Item & Média \\
\hline Alegre & 5,98 \\
\hline Disposto & 5,98 \\
\hline Contente & 5,88 \\
\hline Feliz & 5,65 \\
\hline Animado & 5,60 \\
\hline Tranquilo & 5,46 \\
\hline Orgulhoso & 5,31 \\
\hline Entusiasmado & 5,13 \\
\hline Empolgado & 4,94 \\
\hline
\end{tabular}

As análises inferenciais mostram que existe diferença significativa de percepção de acordo com afastamento por motivo de saúde em relação ao reconhecimento e crescimento profissional, de maneira que pessoas que não se afastaram por motivo de saúde, percebem o fator de forma mais positiva do que pessoas que se afastaram (Mediana=6, $U=53,01$, $p<0,001)$. No que se refere à escolaridade, verifica-se que há diferença de percepção (Mediana=5,55, $U=80,44, p<0,001$ ) em relação aos afetos positivos, de modo que trabalhadores com nível fundamental incompleto (média=8,13) percebem melhor o fator do que trabalhadores com pós-doutorado (média=4,11).

O tipo de jornada de trabalho gerou percepções distintas em relação aos desgastes provenientes do trabalho (Mediana=6, $U=38,96$, $p<0,001)$, de forma que trabalhadores em jornada de 8 horas (média $=5,80$ ) percebem pior quanto a este fator (Mediana=5,8, $\quad U=48,4, \quad p<0,001$ ). Verifica-se ainda que os participantes percebem o fator reconhecimento e crescimento profissional de forma distinta a depender do cargo que ocupam, onde estagiários (média=8,13) percebem melhor o fator do que os analistas (média=5,96).

Em relação ao sexo, notam-se diferenças significativas entre homens e mulheres para o fator organização do trabalho. Mulheres percebem de forma mais positiva que os homens (Mediana=7,80, $U=1,28, \quad p<0,001$ ). Ocupar ou não cargo de chefia gerou diferenças significativas de percepção para o fator reconhecimento e crescimento profissional (Mediana=5,83, $U=168,21, p<0,001$ ). Chefes percebem de forma mais positiva (média=7,12) os fatores do que quem não ocupa cargo de chefia (média=5,44). 


\section{DISCUSSÃO}

O Inventário de Avaliação de Qualidade de Vida no Trabalho - IA_QVT permitiu a identificação das representações dos trabalhadores, evidenciando aspectos positivos, medianos e negativos do contexto de trabalho. Embora o resultado da média global de QVT na empresa tenha se situado em uma zona de bem-estar, é preciso atentar para os elementos que se apresentaram tanto medianos quantos os mais críticos pelo coletivo de trabalhadores que participaram da pesquisa.

Na escala "Nosso Contexto de Trabalho" os fatores "Organização do Trabalho" e "Reconhecimento e Crescimento Profissional" apresentaram-se em uma zona de transição. Estes são resultados que convergem com outros estudos realizados com uso da abordagem teórico-metodológica da EAA_QVT (Albuquerque, 2011; Andrade, 2011; Feitosa, 2010; Figueira, 2014; Fernandes, 2013) onde a avaliação dos fatores foi percebida igualmente como a mais crítica pelos trabalhadores.

Estudos têm apontado relações entre a organização do trabalho, mal-estar no trabalho e adoecimento (Fernandes \& Vasques-Menezes, 2012; Mendes \& Morrone, 2002). Nesse sentido, investir em práticas para melhorar a organização do trabalho parece ser um caminho importante para a promoção de QVT nas organizações (Ahmad, 2013; Fernandes e Ferreira, 2015; Ferreira, 2012; Nogueira e Frota, 2011) e, ao mesmo tempo, para a prevenção de agravos à saúde dos trabalhadores.
Kanan e Arruda (2013, p. 585) destacam que a era digital, caracterizada pela complexidade "dos e nos" processos de trabalho, "oportuniza e demanda dos trabalhadores ações e decisões pessoais e profissionais mais criativas e o desenvolvimento de habilidades para os novos processos que impactam a organização do trabalho", o que torna a gestão da organização do trabalho um grande desafio, tanto para gestores quanto para trabalhadores.

Segundo Ribeiro (2009), o serviço público, embora venha buscando se modernizar, ainda apresenta dois tipos de gestão, um modelo gerencial, abrangendo novas tendências do mercado, e um modelo burocrático, cuja organização do trabalho ainda é regida pela fragmentação das tarefas, de controles técnicos rebuscados e pela falta de autonomia. Nessa linha, chama atenção a percepção negativa sobre a forte cobrança por resultados. Esta cobrança, no âmbito público, é preocupante na medida em que se verifica que, embora o discurso em muitas organizações preconize humanização da gestão, o produtivismo é o que prevalece (Nogueira e Frota, 2011).

De acordo com Tolfo, Silva e Luna (2009), os aspectos efetivos de QVT se situam no nível mais superficial da cultura organizacional que se refletem na organização do trabalho, como política salarial, ambiente psicossocial, processos de trabalho e de comunicação, entre outros. E é nesse nível que surgem as contradições entre os discursos e as 
práticas organizacionais, identificadas nas estratégias de gestão de pessoas e nos programas de QVT.

No que se refere ao reconhecimento e crescimento profissional, os aspectos mais críticos apontados pelos respondentes referemse às poucas oportunidades oferecidas pela empresa para crescimento profissional e à falta de reconhecimento da sociedade pelos serviços prestados. Estudos clássicos e estudos recentes (Ferreira, 2008b; Ferreira, 2012; Hackman e Oldham, 1975; Huang et al., 2007; Lee et al., 2013; Santos, 2014; Walton, 1973) têm, sistematicamente, apontado o papel do reconhecimento e das oportunidades de crescimento na carreira como bases para promoção de vivências de bem-estar e de QVT. Esta é uma razão pela qual este fator deve ser um eixo de investigação e intervenção nos contextos organizacionais.

Ferreira, Alves e Tostes (2009) definem alguns pressupostos estratégicos para operacionalizar a abordagem de QVT preventiva nas organizações, destacando entre eles a necessidade de desenvolvimento de um modelo de gestão do trabalho que preconize a valorização dos trabalhadores e a promoção do reconhecimento individual e coletivo. Li e Yeo (2011), por sua vez, ressaltam que o reconhecimento impacta positivamente na QVT, ilustrando alguns aspectos que se relacionam ao fator "Reconhecimento e Crescimento Profissional", como o reconhecimento pelo trabalho bem feito, a possibiliblidade de crescimento e o trabalho desafiador. Ferreira (2008b, p. 186) aponta ainda que desenvolver ações voltadas ao reconhecimento é "salutar para recuperar o sentido humano do trabalho e superar a ênfase da ideologia do desempenho e resultados, criando bases concretas para percepção de satisfação do trabalho".

Em relação à escala "Práticas de Gestão", os itens avaliados mais negativamente referemse à participação dos trabalhadores nas decisões sobre a organização das tarefas e ao modo de gestão que supervaloriza a obediência à hierarquia. Os itens situaram-se, na escala psicométrica, na zona de mal-estar dominante.

Segundo Esteves (2008), desde a década de 1920 as práticas de gestão de recursos humanos têm sido objeto de estudos, e desde 1980 a perspectiva de visão do tema desenvolveu-se no âmbito da gestão estratégica de pessoas, pressupondo que a gestão é sistêmica, uma responsabilidade partilhada na empresa, e que os trabalhadores, devido aos seus conhecimentos e capacidades, devem ser vistos como um investimento estratégico para as empresas. Entretanto, Lacombe e Chu (2008) sugerem que fatores institucionais, como acionistas, legislação trabalhista ou concorrentes, apresentam efeitos por vezes determinantes sobre as práticas de gestão. Esses fatores devem ser, portanto, considerados na construção de práticas de gestão que busquem o bem-estar dos trabalhadores. Barros 
(2007) destaca que no contexto das organizações atuais ainda encontra-se, nas práticas de gestão, a visão mecanicista e racionalista, coexistindo e opondo-se à visão humanista.

A escala de desgastes provenientes do trabalho evidenciou aspectos que impactam nos afetos negativos e positivos dos trabalhadores. No contexto pesquisado, sentir-se cansado e trabalhar no limite da sua capacidade foram os itens percebidos como mais críticos (desgastes altos). Por sua vez, como consequência, os afetos negativos em destaque no contexto foram ansiedade e preocupação. Bragard et al. (2012) identificaram a relação entre QVT e outros constructos, como o burnout, identificando emoções como esgotamento emocional e estresse que oferecem risco psicosocial e impactam negativamente na QVT. Paschoal e Tamayo (2008) entendem as emoções e os humores no trabalho como uma dimensão afetiva do bem-estar no trabalho. Os autores afirmam (p. 20), que o "contexto de trabalho apresenta-se como um lugar privilegiado de emoções e, fundamentalmente, de realização e de construção da felicidade pessoal". Ou seja, as atividades são orientadas para objetivos e metas, mas o objetivo final é a busca da felicidade (Dupuis et al., 1989). Assim, entende-se que investigar o impacto dos afetos sobre o bem-estar pode subsidiar gestores na identificação de estratégias de promoção de QVT.

\section{CONCLUSÃO}

Os resultados encontrados na pesquisa permitiram alcançar o objetivo proposto, de identificar as percepções dos trabalhadores acerca dos fatores que estruturam a qualidade de vida no trabalho em seus contextos laborais. Por meio das análises foi possível confirmar a hipótese geral da pesquisa, de que a avaliação de QVT é globalmente positiva na empresa e que os fatores "Organização do Trabalho" e "Reconhecimento e Crescimento Profissional" são identificados como os mais críticos na percepção dos trabalhadores.

Um limite que pode ser apontado ao trabalho refere-se à dificuldade de realizar análises comparativas de resultados de pesquisas nacionais e internacionais. Especialmente no Brasil, ainda observa-se uma baixa produção científica no tema (Mendonça \& Araújo, 2016). De acordo com Alves (2010, p.77), "a diversidade de instrumentos de medidas, a qual fundamenta seus conceitos distintos sobre o significado de QVT, pode dificultar a comparação dos resultados nacionais com os resultados de estudos conduzidos em outros países". Apesar dessa limitação, ressalta-se que, no âmbito da EAA_QVT, já foram realizadas diversas pesquisas no serviço público brasileiro, que têm evidenciado traços comuns do perfil das políticas de QVT desses órgãos, o que pode nortear políticas macro para essas instituições. 
Algumas contribuições sobre a presente pesquisa merecem destaque. Investigações dessa natureza subsidiam a consolidação da abordagem da EAA_QVT, abrindo espaço para a realização de estudos comparativos e o aprofundamento teórico da temática (p.ex. estudos comparativos entre os setores judiciário e executivo). Esses estudos podem ser incluídos em uma agenda de pesquisa relevante para o avanço dos estudos da temática. Na perspectiva organizacional, os resultados propiciam a elaboração de políticas que possam nortear as práticas de gestão de pessoas que promovam a

\section{REFERÊNCIAS}

Abarqhouei, N. S.; Nasab, H. H. (2011). Total ergonomics and its impact in musculoskeletal disorders and quality of work life and productivity. Open Journal of Safety Science and Technology, 1, 79-88.

Ahmad, S. (2013). Paradigms of quality of work life. Journal of Human Values, 19 (1), 73-82.

Aketch, J. R.; Odera, 0.; Chepkuto, P.; Okaka, 0. (2012). Effects of quality of work life on job performance: theorical perspectives. Research Journal of Social Science , 4(5), 383388.

Albuquerque, V. P. (2011). Qualidade de Vida no Trabalho, BemEstar e Mal-Estar Sob a Ótica de Trabalhadores de Uma Agência Reguladora Brasileira. Dissertação de mestrado, Programa de Pós-Graduação em Psicologia Social, do Trabalho e das Organizações (PSTO), Universidade de Brasília, Brasília, DF, Brasil.

Alves, W. F. (2010). Qualidade de vida no trabalho: indicadores e instrumentos de medidas. Diálogos e Saberes, 6 (1), 77 87.

An, J. Y.; Yom, Y. H.; Ruggiero, J. S. (2011). Organizational culture, quality of work life, and organizational effectiveness in Korean University. Journal of Transcultural Nursing, 22(1), 22-30.

Antunes, R. (2008). As formas de padecimento no trabalho. Saúde e sociedade, 17(1), 7-8. qualidade de vida no trabalho, aliando bemestar e resultados organizacionais. Do ponto de vista social, a promoção da QVT e o crescimento organizacional poderão impactar nos serviços prestados pelas instituições públicas, cujo objetivo central deve ser a cidadania. Por fim, segundo Leite, Ferreira e Mendes (2009, p.111) o que se espera, na esfera social, é que a política de QVT permita "redesenhar os modelos de gestão para que os trabalhadores transitem da posição histórica de mera mão de obra para a posição futura de ter a obra em suas mãos".

Andrade, P. P. (2011). Sentimento de (in) justiça na Justiça: fatores (des) estruturantes de QVT sob a ótica dos servidores de um órgão do poder judiciário. Dissertação de mestrado, Programa de Pós-Graduação em Psicologia Social, do Trabalho e das Organizações (PSTO), Universidade de Brasília, Brasília, DF, Brasil.

Amalberti, R.; Montmollin, M.; Theureau, J. (Orgs.). (1991). Modèles en analyse du travail. Liège: Mardaga.

Barros, A.R.O. (2007). Comprometimento organizacional: um estudo de suas relações com práticas de gestão de pessoas e intenção de permanência. Dissertação de mestrado, Programa de Pós-Graduação em Administração, Universidade Federal da Bahia, Salvador, BA, Brasil.

Bragard, I.; Dupuis, G.; Razavi, D.; Reynaert, C.; Etienne, A.M. (2012). Quality of work life in doctors working with cancer patients. Occupational Medicine, 62, 34-40.

Brasil (2012). Resolução No 196/96. Recuperado de http:// conselho.saude.gov.br/web_comissoes/conep/arquivos/ resolucoes/23_out_versao_final_196_ENCEP2012.pdf.

Brunault, P.; Fouquereau, E.; Colombat, P.; Gillet, N.; El-Hage, W.; Camus, V.; Gaillard, P. (2013). Do transactive memory and participative teamwork improve nurses' quality of work life? Western Journal of Nursing Research, 36 (3), 329-345. 
Cervo, A. L.; Bervian, P. A.; Da Silva, R. (2007). Metodologia científica. $6^{\mathrm{a}}$ ed. São Paulo: Pearson Prentice Hall.

Cooper, D. R.; Schindler, P. S. (2003). Métodos de pesquisa em administração (7a ed.). São Paulo: Bookman.

Demo, P. (2011). Introdução à Metodologia da Ciência. $2^{\mathrm{a}}$ ed. São Paulo: Atlas.

Dupuis G; Perrault J; Lambany M; Kennedy E; David P. (1989). A new tool to assess quality of life: the quality of life systemic inventory. Qual Life Cardiovasc Care, 5, 36-45.

Esteves, M. T. F. P. (2008). Práticas de gestão de recursos humanos e atitudes e comportamentos no trabalho: estudo de caso no sector bancário português. Tese de doutorado, Programa de Psicologia Social e das Organizações, Instituto Superior de Ciências do Trabalho e da Empresa (ISCTE), Portugal.

Feitosa, L. R. C. (2010). E se a orquestra faltar? Contexto de produção e qualidade de vida no trabalho dos músicos da Orquestra Sinfônica de Teresina/PI. Dissertação de Mestrado, Programa de Pós-Graduação em Psicologia Social, do Trabalho e das Organizações (PSTO), Universidade de Brasília, Brasília, DF, Brasil.

Fernandes, L. C. (2013). "Estamos o tempo todo enxugando gelo": qualidade de vida no trabalho e vivências de bemestar e mal-estar em um órgão do Poder Judiciário. Dissertação de Mestrado, Programa de Pós-Graduação em Psicologia Social, do Trabalho e das Organizações (PSTO), Universidade de Brasília, Brasília, DF, Brasil.

Ferreira, M. C. (2008a). A Ergonomia da atividade se interessa pela qualidade de vida no trabalho? Reflexões empíricas e teóricas. Cadernos de Psicologia Social e do Trabalho, 11, 83-99.

Ferreira, M.C. (2008b). 0 que pensam os trabalhadores franceses sobre as novas exigências do trabalho? In: Dal Rosso, S. \& Fortes, J. A. A. S. (Orgs.). Condições de trabalho no limiar do século XXI (pp. 173-188). Brasília: Épocca.

Ferreira, M.C. (2012). Qualidade de Vida no Trabalho. Uma Abordagem Centrada no Olhar dos Trabalhadores. $2^{\text {a }}$ edição. Paralelo 15.

Ferreira, M.C.; Paschoal, T.; Ferreira, R.R. (2013). Qualidade de Vida no Trabalho: Política e Programa para uma empresa de tecnologia da informação. Relatório Técnico. Brasília DF.

Ferreira, M. C., Alves, L. \& Tostes, N. (2009). Gestão de qualidade de vida no trabalho (QVT) no serviço público federal: o descompasso entre problemas e práticas gerenciais. Psicologia: Teoria e Pesquisa, 25, 319-327.
Fernandes, E. (1996). Qualidade de Vida no Trabalho: como medir para melhorar. Salvador: Casa da Qualidade.

Fernandes, S.R.P.; Vasques-Menezes, I. (2012). Organização do trabalho: implicações para a saúde do trabalhador. In M. C. Ferreira \& H. Mendonça (Orgs.). Saúde e bem-estar no trabalho: dimensões individuais e culturais (pp. 261-275). São Paulo: Casa do Psicólogo.

Fernandes, L.C.; Ferreira, M.C. (2015). Qualidade de vida no trabalho e risco de adoecimento: estudo no poder judiciário brasileiro. Psicologia USP, 26(2), 296-306.

Figueira, T. G. (2014). Bem-estar, mal-estar e qualidade de vida no trabalho em uma instituição pública brasileira. Tese de doutorado, Universidade de Brasília, Programa de PósGraduação em Psicologia Social, do Trabalho e das Organizações (PSTO), Brasília, Brasil.

Gil, A. C.; (2009). Estudo de Caso. São Paulo: Atlas.

Hackman, J. R.; Oldham, G. R. (1975). Development of the Job Diagnostic Survey. Journal of Applied Psychology, 60 (2), 159-170.

Huang, T.C.; Lawler, J.; Lei, C.Y. (2007). The effects of quality of work life on commitment and turnover intention. Social Behavior and Personality, 35 (6), 735-750.

Josiah, R. A.; Odera, 0.; Chepkuto, P.; Okaka, 0. (2012). Effects of quality of work life on job performance: theoretical perspectives and literature review. Current Research Journal of Social Science, 4 (5), 383-388.

Kanan, L. A.; Arruda, M. P. (2013). A organização do trabalho na era digital. Estudos de Psicologia (Campinas), 30 (4), 583591.

Koonmeee, K.; Singhapakdi, A.; Virakul, B.; Lee, D. J. (2010). Ethics institutionalization, quality of work life, and employee job-related outcomes: a survey of human resource managers in Thailand. Journal of Business Research, 63, 20-26.

Lacaz, F. A. C. (2000). Qualidade de vida no trabalho e saúde/ doença. Ciência \& Saúde Coletiva, 5(1), 151-161.

Lacombe, B. M. B; Chu, R. A. (2008). Políticas e práticas de gestão de pessoas: as abordagens estratégicas e institucional. $R A E$, 48 (1), 25-35.

Lawler, E. E. (1982). Strategies for improving the quality of work life. American Psychologist, 37 (5), 486-493.

Lee, Y.W.; Dai, Y.T.; Park, C.G.; McCreary, L.L. (2013). Predicting quality of work life on nurses' intention to leave. Journal of Nursing Scholarship, 45 (2), 160-168. 
Leite, M.P. (1994). Reestruturação produtiva, novas tecnologias e novas formas de gestão da mão de obra. In: Oliveira, B.C.A. (org). 0 mundo do trabalho. Crises e mudanças no final do século. São Paulo: Scritta.

Leite, J. V.; Ferreira, M. C.; Mendes, A. M. (2009). Mudando a gestão da qualidade de vida no trabalho. Psicologia: Organizações e Trabalho, 9(2), 109-123.

Li, J.; Yeo, R. K. (2011). Quality of work life and career development: perceptions of part-time MBA students. Employee Relations, 33 (3), 201-220.

Limongi-França, A. C. (2013). 0 que é qualidade de vida no trabalho? Breve percurso conceitual, histórico e projeções para a próxima década. In: Ferreira, M. C.; Antloga, C. S. X.; Paschoal, T.; Ferreira, R. R. (orgs). (2013). Qualidade de Vida no Trabalho: questões fundamentais e perspectivas de análise e intervenção. Brasília: Paralelo 15.

Limongi-França, A. C. (2004). Qualidade de vida no trabalho QVT: conceitos e práticas nas empresas da sociedade pósindustrial. São Paulo: Atlas.

Marta, J. K. M.; Singhapakdi, A.; Lee, D. J.; Sirgy, M. J. (2013). Journal of Business Research, 66, 381-389.

Martel, J. P.; Dupuis, G. (2006). Quality of work life: theoretical and methodological problems, and presentation of a new model and measuring instrument. Social Indicators Research, 77, 333-368.

Medeiros, L. F. R. \& Ferreira, M. C. (2011). Qualidade de vida no trabalho: uma revisão da produção científica de 19952009. Gestão Contemporânea, Porto Alegre, 8 (9), 9-34.

Mendes, A. M.; Morrone, C. F. (2002). Vivências de prazer, sofrimento e saúde psíquica no trabalho: trajetória conceitual e empírica. Em: A. M. Mendes, L. O. Borges e M. C. Ferreira (Orgs.). Trabalho em transição, saúde em risco (pp. 42-57), Brasília: UnB.

Nadler, D. A.; Lawler, E. E. (1983). Quality of work life: perspectives and directions. Organizational Dinamics, 11 (3), 20-30.

Nayeri, N. D.; Salehi, T.; Noghabi, A.A.A. (2011). Quality of work life and productivity among Iranian nurses. Contemporary Nurse, 39 (1), 106-118.

Nogueira, C.V.; Frota, F. H. S.(2011). Qualidade de vida no trabalho: percepções sobre sua importância como política de valorização no serviço público. Conhecer - Revista do Mestrado Profissional em Planejamento em Políticas Públicas, 1 (3), 31-58.

Organização Internacional do Trabalho - OIT (2013). Doenças profissionais são as principais causas de mortes no trabalho. http://www.oitbrasil.org.br/content/doencasprofissionais-sao-principais-causas-de-mortes-no-trabalho. Acesso em 09/06/2016.

Ouriveis, M. (2013). Acumulação flexível, tecnologia e mudanças no mundo do trabalho: da reestruturação produtiva aos home offices. Estudos do Trabalho: 12, 1-23.

Paschoal, T.; Tamayo, A. (2008). Construção e validação da escala de bem-estar no trabalho. Avaliação Psicológica, 7 (1), 11-22.

Pedroso, B.; Pilatti, L. A. (2010). Revisão literária dos modelos clássicos de avaliação da qualidade de vida no trabalho: um debate necessário. Qualidade de vida: evolução, conceitos e práticas no século XXI, 197-206.

Pedroso, B.; Pillati, L. A.; Santos, C. B.; Santos Júnior, G. (2010). Potencial motivador do trabalho: tradução e adaptação cultural do instrumento de Hackman e Oldham. Revista Produção Online, 10 (3), 670-697.

Ribeiro, C. V. S. (2009). A saúde do servidor público em tempos de gerencialismo. Encontro Nacional da Associação Brasileira de Psicologia Social, 15, Maceió. Maceió: UFAL, 2009.

Rodrigues, M. V. C. (2011) - Qualidade de Vida no Trabalho: evolução e análise no nível gerencial. $13^{\mathrm{a}}$ ed. São Paulo: Ed. Vozes.

Sampaio, J. R. (2012). Qualidade de vida no trabalho: perspectivas e desafios atuais. Revista Psicologia Organizacional e Trabalho, 12 (1), 121-136.

Santos, L.A. (2014). "Quando chega domingo, fico triste de ter que trabalhar na segunda": A qualidade de vida no trabalho em questão no serviço público federal. Tese de doutorado, Universidade de Brasília, Programa de PósGraduação em Psicologia Social, do Trabalho e das Organizações (PSTO), Brasília, Brasil

Sirgy, M. J.; Efraty, D.; Siegel, P.; Lee, D. (2001). A New Measure of Quality of Work Life (QWL) Based on Need Satisfaction and Spillover Theories. Social Indicators Research, 55 (3), 241-302.

Tolfo, S. R.; Silva, N.; Luna, I. N. (2009). Cultura organizacional, identidade e qualidade de vida no trabalho: articulações e sugestões de pesquisas em organizações. Pesquisas e práticas psicossociais, 4 (1), 6-16.

Walton, R. E. Quality of Work Life: What is it? (1973). Cambridge Sloan Management Review , 15 (1), 11-21.

Werther , W.; Davis, K. (1983). Administração de pessoal e recursos humanos. São Paulo: McGraw Hill. 
Westley, .W. A. (1979). Problems and Solutions in the Quality of Working Life. Human Relations, 2 (32), 113-23.

Vasconcelos, A. F. (2001). Qualidade de vida no trabalho: origem, evolução e perspectivas. Caderno de Pesquisas em Administração, 8 (1).
Zhao, X. W.; Sun, T.; Cao, Q.; Li, C.; Duan, X.; Fan, L.; Liu, Y.; (2012). The impact of quality of work life on job embeddedness and affective commitment and their coeffect on turnover intention of nurses. Journal of Clinical Nursing, 22, 780-788. 


\section{MAL-ESTAR E BEM-ESTAR NO TRABALHO: REPRESENTAÇÕES DE TRABALHADORES DE EMPRESA PÚBLICA BRASILEIRA}

Veruska Albuquerque Pacheco

\section{RESUMO}

O objetivo desta pesquisa foi mapear as principais fontes de bem-estar e mal-estar no trabalho com base nas representações de trabalhadores de uma empresa pública brasileira. A pesquisa foi baseada no referencial teórico da Ergonomia da Atividade Aplicada à Qualidade de Vida no Trabalho - EAA_QVT. Participaram 5.833 pessoas, correspondendo a $47,2 \%$ do coletivo de empregados no momento do estudo. Utilizou-se a versão eletrônica do Inventário de Avaliação de Qualidade de Vida no Trabalho - IA_QVT como instrumento. Os resultados indicam que as principais fontes de mal-estar no trabalho do grupo relacionam-se aos seguintes aspectos: organização burocrática do trabalho; condições de trabalho inadequadas e deslocamento desgastante; relacionamentos conflituosos e tratamento desigual; desvalorização do mérito técnico; falta de valorização e reconhecimento pela sociedade; injustiça e iniquidade; e falta de perspectiva de crescimento profissional. Por sua vez, as principais fontes de bem-estar no trabalho identificadas na pesquisa são: importância e significado do trabalho; relações de trabalho harmoniosas; relevância social do trabalho e oportunidade de desenvolver competências; estabilidade e benefícios; fazer o que gosta; e condições de trabalho confortáveis. Os resultados fornecem pistas que podem sinalizar caminhos para a busca pelo bem-estar no trabalho no contexto organizacional estudado.

\section{ABSTRACT}

The objective of this research was to map the main sources of well-being and illbeing at work based on representations of employees of a Brazilian public company. The research was based on the theoretical framework of Activity Ergonomics Applied to Quality of Work Life (AEA_QWL). 5,833 people participated, representing $47.2 \%$ of the group of employees at the time of the study. The electronic version of the Evaluation Inventory of Quality of Work Life (EI_QWL) was used as a tool. The results indicate that the main sources of malaise at work in the group relate to: bureaucratic organization of work; inadequate working conditions and exhausting shift; conflictual relationships and unequal treatment; devaluation of the technical merit; lack of appreciation and recognition by society; injustice and iniquity; and lack of professional growth perspective. On the other hand, the main sources of wellbeing at work identified in the survey are: importance and meaning of the work; harmonious labor relations; social relevance of work and opportunity to develop skills; stability and benefits; do what you like; and comfortable working conditions. The results provide clues that may signal paths to search for well-being at work in the organizational context studied.

\section{PALAVRAS-CHAVE:}

Mal-estar no trabalho; bem-estar no trabalho; qualidade de vida no trabalho; ergonomia da atividade; empresa pública.

KEYWORDS:

Malaise at work; well-being at work; quality of work life; activity ergonomics; public company. 


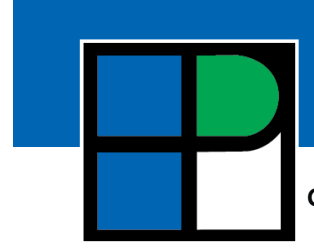

\section{INTRODUÇÃO}

O mundo do trabalho tem passado, nas últimas décadas, por mudanças drásticas. Grande parte delas é reflexo do advento da reestruturação produtiva. Como frutos dessa reestruturação destacam-se a internacionalização do mercado, a revolução tecnológica e a regulação do trabalho que demandou mudanças nas relações de trabalho, como por exemplo, a flexibilidade salarial, da jornada de trabalho e das estruturas de negociação coletiva (Martins e Molinaro, 2013). Essas mudanças vêm gerando, desde a década de 1970, grandes impactos na organização da produção e têm como consequências principais a intensificação e a precarização do trabalho (Albuquerque, 2011; Dal Rosso, 2008; Green, 2004; Oliveira, 2010; Santos, 2014).

Estudos (Castel, 2003; Direnzo e Greenhaus, 2011; Ferreira, 2008) têm evidenciado os impactos da reestruturação produtiva sobre os trabalhadores e depreende-se que há uma relação próxima entre esses impactos e o mal-estar no trabalho. Esse contexto impõe novos desafios aos trabalhadores, que precisam desenvolver estratégias para mediar e minimizar os impactos do mal-estar.

Tendo este cenário de mudanças como referência, o objetivo geral desta pesquisa foi mapear as principais fontes de bem-estar e malestar no trabalho com base nas representações de trabalhadores de uma empresa pública brasileira.

Sob o olhar acadêmico, este estudo justificase pela importância de investigação das fontes de bem-estar e mal-estar no trabalho que propiciem reflexões e aprimoramento da literatura científica sobre as temáticas em questão. Além disso, objetiva-se aprimorar o quadro teórico- metodológico que embasa o estudo, a Ergonomia da Atividade Aplicada à Qualidade de Vida no Trabalho - EAA_QVT (Ferreira, 2012). Na perspectiva aplicada, destaca-se a relevância de se conhecer as fontes de mal-estar e bem-estar no trabalho tendo como base as representações dos trabalhadores para a construção de políticas que possibilitem uma transformação organizacional inovadora e efetiva, que equilibre bem-estar e objetivos organizacionais. Do ponto de vista social, estudos dessa natureza, em instituições públicas, podem possibilitar a melhoria da gestão organizacional e dos serviços prestados por elas, ou seja, o efetivo exercício da cidadania, garantindo assim o cumprimento de seu papel social.

\section{Mal-Estar e Bem-Estar no Trabalho}

Os constructos bem-estar e mal-estar no trabalho têm sido analisados como elementos para se compreender a percepção do indivíduo sobre o seu contexto de trabalho. Percebe-se que há pouca convergência entre os conceitos, ainda escassos, especialmente sobre o mal-estar no trabalho.

Todeschini e Ferreira (2013) e Araújo (2010) destacam que nos últimos cinquenta anos um conjunto extenso de doenças profissionais e do trabalho têm surgido como efeito e consequência das vivências duradouras de mal-estar no trabalho, destacando números crescentes de acidentes de trabalho, traumatismos em geral, distúrbios músculo-esqueléticos, transtornos mentais e o burnout. Este cenário, por si só, serve como justificativa à importância de se discutir e investigar sobre o mal-estar no trabalho e seus reflexos sobre os trabalhadores. 
Apesar de ser crescente o volume de pesquisas sobre o mal-estar no trabalho, a definição clara do termo é difusa e residual na literatura. O conceito costuma trazer em seu bojo associações com o sofrimento no trabalho, como se sofrimento fosse consequência do mal-estar e o mal-estar consequência do sofrimento (Antloga e Avelar, 2013; Antloga, Pinheiro, Maia e Lima, 2014; Bauman, 1998).

O mal-estar no trabalho surge, segundo Périco e Justo (2011), como uma alienação e como resultado da impossibilidade de alcançar a sublimação no trabalho, seja por questões internas (psíquicas) ou externas (de ordem social). Segundo estes autores (p. 155), "de forma fatídica, via de regra, a grande massa explorada no trabalho carrega a infelicidade de se ver distante destas condições, necessárias à sublimação no trabalho".

De acordo com Bendassoli (2011, p. 67) "o mal-estar na civilização é, na verdade, um mal-estar do trabalho". O autor discute como se construiu ao longo do tempo a relação do homem com o trabalho, e associa o mal-estar com o sofrimento no trabalho, e aponta as clínicas do trabalho como alternativas de intervenção aos seus impactos.

Buscando uma definição do mal-estar no trabalho, Ferreira e Seidl (2009) destacam o caráter dialético do bem-estar e do mal-estar que coabitam o mundo do trabalho e descrevem o conceito como uma espécie de "reverso da medalha": compreende-se melhor o mal-estar no trabalho pela ausência dos elementos estruturantes do bem-estar no trabalho.

Entre os estudos identificados, percebe-se um predomínio de pesquisas que buscam relacionar o mal-estar no trabalho com alguns fatores que são promotores da sua representação, como condições precárias de trabalho, organização do trabalho inadequada e esgotamento profissional (Araújo, Sena, Viana e Araújo, 2005; Chávez, 2009; Maciel, Sena e Saboia, 2006). Outros estudos apontam o mal-estar relacionando-o a variáveis individuais, como vivências subjetivas na infância (Silva, 2005) e estresse (Aznar, Rodríguez e Aznar, 2006).

Identifica-se ainda uma diversidade de estudos sobre o mal-estar docente (Aznar e Aznar, 2006; Garcia e Llorens, 2003; Pinto, Goes, Katrein e Barreiro, 2013; Rauber e Rebolo, 2011; Reis, 2013; Silva, 2005; Timm, Mosquera e Stobäus, 2010). Estes apontaram como fontes aspectos relacionados à intensificação do trabalho, às condições de trabalho, à saturação de tarefas e à burocracia e política institucional que levam ao sofrimento no trabalho, ao desequilíbrio entre vida profissional e pessoal e à alienação.

O estudo de Antloga et al. (2014), realizado com trabalhadores de uma instituição pública federal, identificou as principais vivências de malestar no trabalho naquele contexto. Segundo a pesquisa, as representações de mal-estar estão relacionadas aos seguintes fatores: gestão organizacional; condições físicas de trabalho; desigualdade de tratamento entre cargos e carreiras; e injustiça e falta de autonomia.

Assim como ocorre com a definição de malestar no trabalho, não há consenso na literatura científica sobre o conceito de bem-estar no trabalho (Schulte e Vainio, 2010; Gomide, Silvestrin e Oliveira, 2015). Estudos sobre o bem-estar no trabalho começaram a se destacar na literatura a partir da década de 1950, quando se discutia o bem-estar como felicidade, sendo o bem-estar 
subjetivo como um indicador de qualidade de vida, cujos estudos giram ao redor de duas correntes filosóficas: hedonismo e eudaimonismo (Ryan e Deci, 2001; Santos e Ceballos, 2013).

O conceito de bem-estar no trabalho, por sua vez, pode ser compreendido com base em três componentes associados a vínculos positivos com o trabalho: satisfação no trabalho, envolvimento com o trabalho e comprometimento organizacional afetivo. Nessa linha, o constructo envolve um modelo hierárquico de felicidade (Siqueira e Padovam, 2008).

Aproximar os termos bem-estar e felicidade é também a perspectiva de Paschoal, Torres e Porto (2010). Nesse sentido, bem-estar no trabalho é entendido como a prevalência de emoções positivas no trabalho e a percepção do indivíduo de que sua atuação permite $\mathrm{o}$ desenvolvimento de seus potenciais e alcance de suas metas de vida. Dessa forma, o bem-estar no trabalho inclui aspectos afetivos e cognitivos e é organizado em torno de três fatores: afeto positivo, afeto negativo e realização pessoal no trabalho.

Pinto et al. (2013, p.46) afirmam que "o bem-estar pressupõe algum tipo de recompensa no exercício da atividade profissional". Essa recompensa, segundo os autores, independe de ser uma retribuição financeira ou o alcance dos objetivos atribuídos ao trabalho.

Os conceitos de bem-estar e mal-estar no trabalho adotados nesta pesquisa vão ao encontro do que foi proposto por Ferreira e Seidl (2009), em sintonia com a abordagem denominada Ergonomia da Atividade Aplicada à Qualidade de Vida no Trabalho (EAA_QVT). Segundo a abordagem, bemestar no trabalho diz respeito a um sentimento agradável que tem origem nas situações de trabalho e se manifesta de forma individual ou coletiva.

O mal-estar no trabalho, por sua vez, referese a sentimentos desagradáveis que se originam com base nas situações de trabalho se manifestando individual ou coletivamente (Ferreira, 2012). Esse estado psicológico se configura como uma representação mental dos trabalhadores, sendo fruto da avaliação que estes fazem dos fatores que estruturam a QVT: condições, organização e relações socioprofissionais de trabalho, reconhecimento e crescimento profissional e elo trabalho-vida social. Segundo o autor (p.180-181):

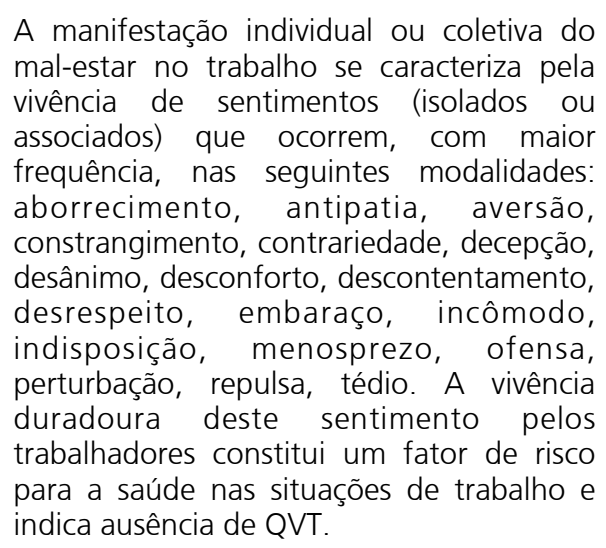

Tendo como base a EAA_QVT (Albuquerque, 2011; Andrade, 2011; Branquinho, 2010; Daniel, 2012; Figueira, 2014; Fernandes, 2013; Maia, 2014; Medeiros, 2012; Santos, 2014), estudos têm mostrado que as vivências de bem-estar e mal-estar no trabalho estão relacionadas a cinco fatores que estruturam a Qualidade de Vida no Trabalho (QVT): condições de trabalho; organização do trabalho; relações socioprofissionais de trabalho; reconhecimento e crescimento profissional; elo trabalho-vida social (Ferreira, 2012). Nesse sentido, faz-se necessário atuar sobre esses fatores para se remover ou amenizar os impactos negativos causados pelo mal-estar no trabalho. 


\section{MÉTODO}

Trata-se de uma pesquisa de natureza empírica de caráter qualitativo, caracterizada como estudo de caso. Pesquisas qualitativas têm como características a compreensão como princípio do conhecimento, a busca pela construção subjetiva da realidade, a descoberta e a construção de teorias, e por ser uma ciência baseada em textos (Günther, 2006). O estudo de caso caracteriza-se pela preservação do caráter unitário do fenômeno sem separá-lo do seu contexto, investigando-o in loco, com profundidade (Gil, 2009).

\section{Breve Caracterização do Campo de Pesquisa:} instituição e missão

A pesquisa foi desenvolvida em uma empresa pública vinculada ao poder executivo federal, criada com o objetivo de modernizar e dar agilidade a setores estratégicos da Administração Pública Brasileira. A empresa tem como missão disponibilizar informações e prover soluções tecnológicas para o êxito da gestão do Estado em atendimento à sociedade brasileira. Sua visão preconiza ser um centro de informações e soluções tecnológicas para o Brasil.

Os produtos e serviços principais oferecidos pela empresa são os seguintes: informações de governo aberto; soluções de tecnologia da informação; consultoria em tecnologia da informação; sistemas estruturadores do Governo Federal; segurança da informação; e sistemas de tecnologia da informação para uma rede logística nacional inteligente.

Os componentes estratégicos da organização estabelecem como premissa:

- Conquistar e aprimorar o reconhecimento dos clientes: governo, sociedade e cidadão;
- Prestar serviços com efetividade e segurança;

- Desenvolver e empregar soluções tecnológicas inovadoras;

- Realizar parcerias e cooperações para o desenvolvimento de soluções;

- Praticar gestão integrada e participativa;

- Manter os empregados comprometidos e motivados;

- Atuar com ética, transparência e sustentabilidade social, ambiental e econômica.

A empresa possui diversas regionais, sendo duas em Brasília e as demais nas cidades de São Paulo, Rio de Janeiro, Recife, Curitiba, Salvador, Belém, Belo Horizonte, Porto Alegre, Fortaleza e Florianópolis.

\section{Participantes}

À época da coleta de dados, a empresa tinha em seu quadro funcional 12.357 empregados. Destes, 7.677 fazem parte do quadro interno, enquanto os demais compõem o pessoal de serviço externo.

Participaram da pesquisa 5.833 pessoas, correspondendo a $47,2 \%$ do coletivo de empregados. Do total de empregados do quadro interno, participaram 4.065 respondentes $(47,2 \%)$. Esta adesão evidencia a efetividade das atividades de sensibilização realizadas, que garantiram uma participação significativa dos empregados na pesquisa. O perfil sociodemográfico e profissiográfico dos participantes ( $\mathrm{n}$ válidos $=4.436$ ) é demonstrado na tabela 1. 
Tabela 1

Resumo do perfil sociodemográfico e profissiográfico dos participantes

\begin{tabular}{|c|c|c|c|c|c|c|c|c|}
\hline \multicolumn{9}{|c|}{ Dados Sociodemográficos } \\
\hline \multirow{2}{*}{ Idade } & $\mathrm{N}$ & \multirow{2}{*}{\multicolumn{3}{|c|}{$\begin{array}{l}\text { Média } \\
46,75\end{array}$}} & \multicolumn{4}{|c|}{ DP } \\
\hline & 5.260 & & & & \multicolumn{4}{|c|}{11,61} \\
\hline \multirow{2}{*}{ Gênero } & $\mathrm{N}$ & \multirow{2}{*}{\multicolumn{3}{|c|}{$\frac{\text { Masculino }}{3.353(62 \%)}$}} & \multirow{2}{*}{\multicolumn{4}{|c|}{$\begin{array}{l}\text { Feminino } \\
2.038(38 \%)\end{array}$}} \\
\hline & 5.391 & & & & & & & \\
\hline \multirow[b]{2}{*}{ Estado Civil } & $\mathrm{N}$ & Casado & Solteiro & \multicolumn{2}{|c|}{ Divord Separ } & Outros & \multicolumn{2}{|c|}{ Viúvo } \\
\hline & 5.418 & $3.182(58,7 \%)$ & $\begin{array}{c}1.524 \\
(28,1 \%)\end{array}$ & \multicolumn{2}{|c|}{$498(9,2 \%)$} & $\begin{array}{c}151 \\
(2,8 \%)\end{array}$ & \multicolumn{2}{|c|}{$63(1,2 \%)$} \\
\hline \multirow{2}{*}{ Escolaridade } & $\mathrm{N}$ & Fund. & \multicolumn{2}{|c|}{ Médio } & \multicolumn{2}{|c|}{ Superior } & \multicolumn{2}{|c|}{ Pós-Grad. } \\
\hline & 5.426 & 350 & \multicolumn{2}{|c|}{1.379} & \multicolumn{2}{|c|}{1.963} & \multicolumn{2}{|c|}{1.734} \\
\hline \multicolumn{9}{|c|}{ Dados profissiográficos } \\
\hline \multirow[b]{2}{*}{$\operatorname{Cargo}^{*}$} & $\mathrm{~N}$ & NA & $\mathrm{AX}$ & \multicolumn{2}{|l|}{ TE } & TR & $\mathrm{AP}$ & ES \\
\hline & 5.009 & $\begin{array}{c}2.527 \\
(50,4 \%)\end{array}$ & $\begin{array}{c}1.085 \\
(21,7 \%)\end{array}$ & \multicolumn{2}{|c|}{$1.005(20,1 \%)$} & $\begin{array}{c}298 \\
(5,9 \%)\end{array}$ & $62(1,2 \%)$ & $\begin{array}{c}32 \\
(0,6 \%)\end{array}$ \\
\hline \multirow{2}{*}{ Forma de Admissāo } & $\mathrm{N}$ & \multicolumn{2}{|c|}{ Concurso Público } & \multirow{2}{*}{\multicolumn{3}{|c|}{\begin{tabular}{|c|} 
Processo Seletivo \\
$2.093(46,5 \%)$
\end{tabular}}} & \multicolumn{2}{|c|}{ Nomeaçāo } \\
\hline & 4.498 & \multicolumn{2}{|c|}{$2.378(52,9 \%)$} & & & & \multicolumn{2}{|c|}{$27(0,6 \%)$} \\
\hline \multirow{2}{*}{ Tempo de Serviço (anos) } & $\mathrm{N}$ & & Média & & & & DP & \\
\hline & 5.299 & & 16,49 & & & & 12,96 & \\
\hline & $\mathrm{N}$ & & Média & & & & DP & \\
\hline Tempo na Lotaçao (anos) & 4.481 & & 8,68 & & & & 8,88 & \\
\hline & $\mathrm{N}$ & Dir. 1 & Dir. 2 & Dir. 3 & & r. 4 & Dir. 5 & Dir. 6 \\
\hline Diretoria** & 3.855 & $\begin{array}{l}1.387 \\
(36 \%)\end{array}$ & $\begin{array}{c}1.300 \\
(33,7 \%)\end{array}$ & $\begin{array}{c}491 \\
(12,7 \%)\end{array}$ & & $\begin{array}{l}09 \\
6 \%)\end{array}$ & $187(4,9 \%)$ & $81(2,1 \%)$ \\
\hline
\end{tabular}

* AN: Analista; AX: Auxiliar; TE: Técnico; TR: Terceirizado; AP: Jovem Aprendiz; ES: Estagiário.

** Os nomes das diretorias foram modificados para preservar a confidencialidade da organização.

\section{Instrumentos}

Utilizou-se o Inventário de Avaliação de Qualidade de Vida no Trabalho - IA_QVT, versão 2.0 (Ferreira, Paschoal e Ferreira, 2013). O IA_QVT é um instrumento quanti-qualitativo que possibilita o diagnóstico e o mapeamento de QVT em contextos organizacionais com base na percepção dos trabalhadores.

$\mathrm{Na}$ parte qualitativa, compõem o instrumento quatro questões abertas. Esta parte do inventário permite refinar os dados quantitativos, enriquecendo e agregando mais precisão aos dados. As questões abertas do IA_QVT são:

- Na minha opinião, Qualidade de Vida no Trabalho é...

- Quando penso no meu trabalho no [Nome do Órgão], o que me causa mais bem-estar é...

- Quando penso no meu trabalho no [Nome do Órgão], o que me causa mais mal-estar é...

- Comentários e Sugestões.
Tendo em vista o objetivo deste artigo, realizou-se um recorte e foram utilizadas duas questões que compõem o instrumento: "Quando penso no meu trabalho no [Nome do Órgão], o que me causa mais bem-estar é..." e "Quando penso no meu trabalho no [Nome do Órgão], o que me causa mais mal-estar é...".

\section{Procedimentos de Coleta e Análise}

Para proceder à coleta, realizaram-se estratégias de sensibilização como palestras e folders. O instrumento foi aplicado via internet, hospedado em sítio externo à empresa, para garantir a segurança das informações e aumentar a participação do público-alvo e confiabilidade das respostas. Na tela inicial de acesso ao instrumento, apresentou-se aos participantes os aspectos éticos em relação à participação voluntária, à possibilidade de desistência de participação sem causar prejuízos ou danos pessoais, à ausência de riscos para as atividades ou para a instituição, ao sigilo dos dados 
e a garantia de anonimato, conforme preconiza a Resolução MS 466/12 do Conselho Nacional de Saúde (que revoga a Resolução 196/96).

Os dados foram tratados com o auxílio do software Alceste - Análise Lexical do Contexto de um Conjunto de Segmentos de Textos, que identifica informações essenciais das respostas a fim de extrair as classes ou núcleos temáticos estruturadores do discurso, oferecendo testes estatísticos organizados para auxiliar a análise dos dados textuais extraídos no texto (Reinert, 1990).

\section{RESULTADOS}

A participação quantitativamente expressiva dos respondentes nas questões abertas do instrumento reforça o papel da sensibilização realizada, evidenciando a confiabilidade dos empregados à pesquisa. Ademais, essa parte do instrumento tem duas contribuições importantes para a investigação científica: de um lado, permite refinar os resultados da parte quantitativa, deixando transparecer informações difíceis de serem captadas nas questões objetivas (fechadas); de outro lado, resulta em um importante espaço de fala para os trabalhadores para acrescentar, explicar e enfatizar outros aspectos julgados importantes pelos participantes.

Após identificados os núcleos temáticos que estruturaram o discurso dos respondentes acerca das fontes de bem-estar e de mal-estar no trabalho, apresenta-se o detalhamento dos principais termos destacados no discurso que foram mapeados no Alceste, que ajudam, em conjunto com a leitura das frases produzidas, a compreender melhor cada um dos núcleos.

\section{Fontes de Mal-Estar no Trabalho}

Na questão "Quando penso no meu trabalho no [Nome do Órgão], o que me causa mais malestar é...", respondida por 5.094 trabalhadores, o Alceste identificou 7 núcleos temáticos, com respectivos percentuais de discurso produzido: Organização Burocrática do Trabalho (25\%); Condições de Trabalho Inadequadas e Deslocamento Desgastante (21\%); Relacionamentos Conflituosos e Tratamento Desigual (15\%); Desvalorização do Mérito Técnico (13\%); Falta de Valorização e Reconhecimento pela Sociedade (10\%); Injustiça e Iniquidade (9\%); e Falta de Perspectiva de Crescimento Profissional (7\%). A Figura 1 ilustra o resultado.

\begin{tabular}{|c|c|c|c|}
\hline Núcleos Temáticos & $\%$ & Exemplos de Segmentos Representativos & $\begin{array}{c}\text { Principais Termos/ } \\
\text { Expressões }\end{array}$ \\
\hline $\begin{array}{c}\text { Organização Burocrática } \\
\text { do Trabalho }\end{array}$ & 25 & $\begin{array}{l}\text { - "A realização de tarefas meramente burocráticas, para } \\
\text { satisfazer a necessidade do processo e não do produto a ser } \\
\text { desenvolvido". } \\
\text { - "Falta de ferramenta que integre as informações, havendo } \\
\text { muito retrabalho". } \\
\text { "A dificuldade de realizar tarefas fundamentais para } \\
\text { conclusão do trabalho. Tarefas relativamente simples se } \\
\text { tornaram tão difíceis de concluir que provocam desânimo". } \\
\text { "O controle de qualidade imposto. Porque temos que seguir } \\
\text { certas regras pré-determinadas, não podemos fugir uma } \\
\text { vírqula". }\end{array}$ & $\begin{array}{l}\text { Burocracia; Controle de } \\
\text { qualidade rígido; } \\
\text { Retrabalho; Falta de } \\
\text { agilidade; Falta de } \\
\text { flexibilidade; Excesso de } \\
\text { normas. }\end{array}$ \\
\hline
\end{tabular}




\begin{tabular}{|c|c|c|c|}
\hline Núcleos Temáticos & $\%$ & Exemplos de Segmentos Representativos & $\begin{array}{l}\text { Principais Termos/ } \\
\text { Expressões }\end{array}$ \\
\hline $\begin{array}{l}\text { Condições de Trabalho } \\
\text { Inadequadas e } \\
\text { Deslocamento } \\
\text { Desgastante }\end{array}$ & 21 & $\begin{array}{l}\text { "O horário que, por não ser flexível, tenho que pegar trânsito } \\
\text { na ida e na volta e, por morar longe, acabo passando } 12 \mathrm{~h} \text { do } \\
\text { meu dia para o trabalho, pois trabalho } 8 \mathrm{~h}, 1 \mathrm{~h} \text { para almoço e, } \\
\text { por causa do trânsito, levo } 1 \mathrm{~h} \text { pra ir e } 1 \mathrm{~h} \text { pra voltar". } \\
\text { "O problema é vir trabalhar e voltar pra casa. } 0 \text { volume de } \\
\text { carros é muito grande, todo dia tem acidentes e } \\
\text { engarrafamentos, às vezes chego no trabalho cansada". } \\
\text { "Ambiente fechado e sem ventilação adequada". } \\
\text { "Ruído excessivo no ambiente de trabalho, prejudicando a } \\
\text { concentração". } \\
\text { "Mal-estar pra mim é a iluminação, é extremamente } \\
\text { inadequada causando dores de cabeça diariamente". }\end{array}$ & $\begin{array}{l}\text { Ventilação, Ruído, } \\
\text { Iluminação e Mobiliário } \\
\text { Inadequados; Mofo; } \\
\text { Longo tempo de } \\
\text { deslocamento; Trânsito. }\end{array}$ \\
\hline $\begin{array}{l}\text { Relacionamentos } \\
\text { Conflituosos e } \\
\text { Tratamento Desigual }\end{array}$ & 15 & $\begin{array}{l}\text { "A arrogância e protecionismo de determinados chefes com } \\
\text { seus subordinados. Para os amigos, tudo; para os inimigos, a } \\
\text { lei". } \\
\text { "Curso de formação somente para os que tomam cafezinhos } \\
\text { juntos e os que não tomam não fazem parte do grupo". } \\
\text { "Os empregados comuns que não são da panelinha não tem } \\
\text { chance de demonstrar o seu potencial, pois não Ihes são } \\
\text { dadas oportunidades, projetos, chefias, responsabilidades". } \\
\text { "Perceber a diferença de tratamento para os preferidos e os } \\
\text { preteridos. Para os amigos, tudo, promoção incondicional, } \\
\text { condescendência com os erros". } \\
\text { "Assédio pesado e desrespeito por parte de algumas } \\
\text { chefias". }\end{array}$ & $\begin{array}{l}\text { Protecionismo; Injustiça; } \\
\text { Fofocas; Conflitos; } \\
\text { Relacionamento difícil; } \\
\text { Falta de Cooperação e } \\
\text { Diálogo. }\end{array}$ \\
\hline $\begin{array}{l}\text { Desvalorização do } \\
\text { Mérito Técnico }\end{array}$ & 13 & $\begin{array}{l}\text { "Decisões tomadas que não levam em consideração as } \\
\text { dificuldades de implementação para o corpo funcional, que } \\
\text { não apresentam alguma razoabilidade em si; interferência } \\
\text { política em decisões de questões técnicas". } \\
\text { "A sobreposição do político sobre o conhecimento técnico } \\
\text { nas decisões puramente técnicas". } \\
\text { "As decisões nem sempre levam em consideração critérios } \\
\text { de justiça nem técnicos, mas amizades e interesses escusos". } \\
\text { "Saber que me crescimento profissional é condicionado a } \\
\text { politicagem. Saber que as promoções são feitas levando em } \\
\text { consideração a capacidade e sim interesses. }\end{array}$ & $\begin{array}{l}\text { Critérios subjetivos de } \\
\text { promoção; Falta de } \\
\text { transparência; } \\
\text { Desvalorização de } \\
\text { critérios técnicos; } \\
\text { Favorecimento. }\end{array}$ \\
\hline $\begin{array}{l}\text { Falta de Valorização e } \\
\text { Reconhecimento pela } \\
\text { Sociedade }\end{array}$ & 10 & $\begin{array}{l}\text { "Desconhecimento da sociedade em relação ao nosso papel } \\
\text { e falta de empenho dos responsáveis pela empresa em brigar } \\
\text { por uma maior valorização profissional com uma } \\
\text { remuneração compatível a outras empresas ou órgãos do } \\
\text { governo federal". } \\
\text { "Saber que a sociedade não valoriza a empresa como } \\
\text { valoriza outros órgãos. A maioria dos cidadãos nem sabe os } \\
\text { serviços que a instituição presta". } \\
\text { "Falta de notoriedade, reconhecimento e relevância da } \\
\text { empresa perante a sociedade". } \\
\text { "O trabalho desenvolvido pela empresa é extremamente } \\
\text { importante no âmbito do governo federal e somos pouco } \\
\text { reconhecidos internamente externamente". }\end{array}$ & $\begin{array}{l}\text { Baixa remuneração; Falta } \\
\text { de reconhecimento e } \\
\text { valorização; Falta de } \\
\text { notoriedade da empresa } \\
\text { perante a sociedade. }\end{array}$ \\
\hline
\end{tabular}




\begin{tabular}{|c|c|c|c|}
\hline Núcleos Temáticos & $\%$ & Exemplos de Segmentos Representativos & $\begin{array}{c}\text { Principais Termos/ } \\
\text { Expressões }\end{array}$ \\
\hline Injustiça e Iniquidade & 9 & $\begin{array}{l}\text { - "Saber que há pessoas ganhando quase o dobro do que eu } \\
\text { ganho pra fazer menos da metade do que eu faço". } \\
\text { "Hoje, na condição de anistiada com } 61 \text { anos, preciso } \\
\text { continuar trabalhando sem esperança de poder me } \\
\text { aposentar com uma vida digna". } \\
\text { - "Agora que posso me aposentar, fazendo os cálculos, dá } \\
\text { vontade de chorar! Só perdi tempo nesta empresa. Agora é } \\
\text { tarde demais". } \\
\text { - "Ter sido injustiçada no passado e continuar pagando por } \\
\text { um erro que não fui eu quem cometeu". }\end{array}$ & $\begin{array}{l}\text { Situação dos Anistiados; } \\
\text { Preocupação com } \\
\text { Aposentadoria; Falta de } \\
\text { reconhecimento pela } \\
\text { dedicação; Injustiça na } \\
\text { distribuição de } \\
\text { gratificações. }\end{array}$ \\
\hline $\begin{array}{l}\text { Falta de Perspectiva de } \\
\text { Crescimento Profissional }\end{array}$ & 7 & $\begin{array}{l}\text { - "Saber que estou indo para o trabalho sem perspectivas de } \\
\text { ascensão na carreira. É realmente muito frustrante". } \\
\text { - "A remuneração é muito baixa e as perspectivas são ainda } \\
\text { piores". } \\
\text { "A inexistência de um plano de carreira real. o sistema de } \\
\text { progressão por mérito é vergonhosamente subjetivo". } \\
\text { "Ver colegas com talentos inestimáveis buscar melhor } \\
\text { remuneração e oportunidade real de crescimento profissional } \\
\text { em outro ramo por falta de incentivo". }\end{array}$ & $\begin{array}{c}\text { Inexistência de } \\
\text { crescimento por } \\
\text { titulação; Progressão } \\
\text { quase impossível; Falta } \\
\text { de incentivo. }\end{array}$ \\
\hline
\end{tabular}

Figura 1. Núcleos temáticos, percentuais e exemplos de segmentos representativos das fontes de mal-estar no trabalho.

\section{Fontes de Bem-Estar no Trabalho}

Na questão "Quando penso no meu trabalho no [Nome do Órgão], o que me causa mais bemestar é...", foram obtidas 4.887 respostas. Nesta questão, o Alceste registrou a existência de 6 núcleos temáticos: "Importância e significado do trabalho"; "Relações de trabalho harmoniosas"; "Relevância social do trabalho e oportunidade de desenvolver competências"; "Estabilidade e benefícios"; "Fazer o que gosta"; e "Condições de trabalho confortáveis". A Figura 2 demonstra 0 resultado.

\begin{tabular}{|c|c|c|c|}
\hline Núcleos Temáticos & $\%$ & Exemplos de Segmentos Representativos & $\begin{array}{l}\text { Principais Termos/ } \\
\text { Expressões }\end{array}$ \\
\hline $\begin{array}{c}\text { Importância e } \\
\text { Significado do Trabalho }\end{array}$ & 24 & $\begin{array}{l}\text { - "Ver o nome da empresa em noticiário nacional e } \\
\text { internacional como sendo a maior empresa de informática } \\
\text { da América Latina dá um orgulho de ser um do quadro aqui } \\
\text { que só Deus sabe". } \\
\text { - "Identificar especialistas que me dão orgulho de pertencer } \\
\text { a empresa". } \\
\text { "Saber que algo estava com problema e eu ajudei a } \\
\text { resolver". } \\
\text { "É fazer parte dessa empresa desde seus áureos tempos, } \\
\text { quando trabalhávamos por amor, sem medir esforços e } \\
\text { sentir orgulho de fazer parte dessa família". }\end{array}$ & $\begin{array}{l}\text { Fazer parte da família; } \\
\text { Maior Empresa de TI da } \\
\text { América Latina; Empresa } \\
\text { conceituada; Orgulho; } \\
\text { Ajudar a resolver } \\
\text { problemas; Gerar produtos } \\
\text { bem desenvolvidos. }\end{array}$ \\
\hline $\begin{array}{l}\text { Relações de Trabalho } \\
\text { Harmoniosas }\end{array}$ & $22 \%$ & $\begin{array}{l}\text { - "Bom relacionamento e cooperação entre colegas de } \\
\text { trabalho". } \\
\text { "A harmonia entre os colegas de trabalho". } \\
\text { "O clima amistoso entre os colegas". } \\
\text { "O convívio com os colegas de trabalho". } \\
\text { "O espírito de companheirismo e clima, em geral, } \\
\text { descontraído". }\end{array}$ & $\begin{array}{l}\text { Equipe cooperativa; Clima } \\
\text { amistoso; Espírito de } \\
\text { companheirismo; } \\
\text { Harmonia; Bom } \\
\text { relacionamento. }\end{array}$ \\
\hline
\end{tabular}




\begin{tabular}{|c|c|c|c|}
\hline Núcleos Temáticos & $\%$ & Exemplos de Segmentos Representativos & $\begin{array}{c}\text { Principais Termos/ } \\
\text { Expressões }\end{array}$ \\
\hline $\begin{array}{l}\text { Relevância Social do } \\
\text { Trabalho e } \\
\text { Oportunidade de } \\
\text { Desenvolver } \\
\text { Competências }\end{array}$ & $19 \%$ & $\begin{array}{l}\text { "Trabalho numa empresa pública que tem como objetivo } \\
\text { fundamental melhorar a vida do cidadão, através de } \\
\text { soluções tecnológicas que melhoram a prestação dos } \\
\text { serviços públicos". } \\
\text { " "A possibilidade de aprender novas tecnologias". } \\
\text { "Participar de um projeto que agrega valor para a } \\
\text { sociedade brasileira". } \\
\text { "Aquisição de novos conhecimentos na área de atuação". }\end{array}$ & $\begin{array}{l}\text { Adquirir novos } \\
\text { conhecimentos; Aprender } \\
\text { novas tecnologias; Agregar } \\
\text { valor para a sociedade; } \\
\text { Bem social; Projetos } \\
\text { relevantes para a } \\
\text { sociedade e os cidadãos; } \\
\text { Crescimento Profissional. }\end{array}$ \\
\hline $\begin{array}{l}\text { Estabilidade e } \\
\text { Benefícios }\end{array}$ & 14 & $\begin{array}{l}\text { - "A segurança do emprego, o salário certo no final do mês, } \\
\text { os benefícios que eu tenho todos os meses e que estão à } \\
\text { minha disposição". } \\
\text { "Os benefícios, como: ticket, plano de saúde e abono } \\
\text { social". } \\
\text { "Salário garantido no final do mês e uma certa estabilidade } \\
\text { em comparação com o mercado privado". }\end{array}$ & $\begin{array}{l}\text { Segurança do emprego; } \\
\text { Benefícios; Estabilidade; } \\
\text { Plano de Saúde, Ticket; } \\
\quad \text { Salário em dia. }\end{array}$ \\
\hline Fazer o que Gosta & 13 & $\begin{array}{l}\text { " "Satisfação em realizar minhas atividades as quais realizo } \\
\text { com prazer. Gosto muito do meu trabalho, faço com amor, } \\
\text { dedicação e qualidade" } \\
\text { "Gosto do que faço, venho trabalhar com alegria e vontade } \\
\text { de desenvolver minhas atividades". } \\
\text { "Gosto de fazer o que faço. Se eu não pudesse realizar essa } \\
\text { atividade, eu iria me sentir mal". }\end{array}$ & $\begin{array}{l}\text { Sensação de Dever } \\
\text { Cumprido; Satisfação; } \\
\text { Prazer; Felicidade. }\end{array}$ \\
\hline $\begin{array}{c}\text { Condições de Trabalho } \\
\text { Confortáveis }\end{array}$ & 8 & $\begin{array}{l}\text { - "O ambiente físico está sempre limpo e cuidado. As } \\
\text { ferramentas são adequadas para o trabalho". } \\
\text { - "As instalações são modernas e confortáveis". } \\
\text { - "Trabalhar em um ambiente limpo, confortável, com } \\
\text { equipamentos ergonômicos sempre disponíveis". }\end{array}$ & $\begin{array}{l}\text { Local confortável; } \\
\text { Ambiente agradável; } \\
\text { Instalações modernas; } \\
\text { Limpeza, lluminação e } \\
\text { Mobiliário adequados. }\end{array}$ \\
\hline
\end{tabular}

Figura 2. Núcleos temáticos, percentuais e exemplos de segmentos representativos das fontes de bem-estar no trabalho.

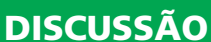

Os resultados encontrados revelaram as percepções de trabalhadores de uma empresa pública acerca de aspectos que propiciam bem-estar e mal-estar em seus contextos de trabalho e que impactam na sua qualidade de vida no trabalho. Em relação ao mal-estar no trabalho, os achados mostram semelhanças com outros estudos, conforme se discute a seguir.

O núcleo "organização burocrática do trabalho" ressalta um problema que parece ser lugar comum no contexto público. De um lado, há um alto nível de cobrança por qualidade; de outro lado, os trabalhadores percebem excesso de normas, retrabalho, lentidão e ausência de flexibilidade. Estudos vêm evidenciando os impactos negativos da organização do trabalho no bem-estar. Daniel (2012) demonstrou as consequências negativas das exigências da organização do trabalho no Custo Humano do Trabalho - CHT, resultando no predomínio de vivências de mal-estar nas dimensões física, cognitiva e afetiva. Considerando a organização do trabalho como elemento constituinte do Contexto de Produção de Bens e Serviços - CPBS (Ferreira e Mendes, 2003) e como eixo de operacionalização do processo produtivo que impacta diretamente na execução das tarefas e no mal-estar de quem as executa (Albuquerque, 2011; Boisvert, 1980; Daniel, 2012; Ferreira, 2012; 
Em relação ao bem-estar, foram evidenciados alguns elementos comuns a outros estudos em contextos públicos ou privados, conforme se apresenta a seguir.

Sobre os núcleos "importância e significado do trabalho", "fazer o que gosta" e "relevância social do trabalho e oportunidade de desenvolver competências" destaca-se o sentido do trabalho. Vários autores têm sublinhado o papel central do trabalho na vida das pessoas, a exemplo de Antunes (1999), Bauman (1998) e Sennet (1999). Outros estudos, seja no âmbito do serviço público ou no âmbito do setor privado, também apontaram o significado do trabalho e sua relevância para a sociedade e o orgulho em fazer parte da instituição como fonte de bem-estar no trabalho (Albuquerque, 2011; Andrade, 2011; Costa, 2011; Ferreira, 2012; Figueira, 2014; Morin et al., 2007; Oliveira, 2010; Santos, 2014). Nesse sentido, é relevante refletir sobre o papel ontológico do trabalho enquanto elemento de constituição dos sujeitos e de construção da identidade.

No que se refere às relações de trabalho harmoniosas, os estudos de Albuquerque (2011), Andrade (2011), Branquinho (2010), Feitosa (2010), apontaram a importância das relações sociais na percepção de bem-estar. Segundo Mendes et al. (2003) as relações de trabalho adequadas podem servir como estratégia para minimizar os impactos negativos de outros aspectos relacionados ao trabalho, ou seja, funcionam como suporte social para o sofrimento (Brusch e Monteiro, 2011; Mendes et al., 2003).

Os núcleos "condições de trabalho confortáveis" e "estabilidade e benefícios" ressaltam a importância investir em condições físicas de trabalho apropriadas e em uma boa política de benefícios. No órgão em questão, a estrutura física do prédio favorece a percepção de bem-estar quanto às condições físicas do ambiente de trabalho (ex. ambiente limpo e confortável, mobiliário adequado); entretanto, a localização do prédio, cujos acessos são mais difíceis, foi apontada como fonte de mal-estar. Isso ilustra a relação dialética do bem-estar e do mal-estar no contexto, dada a contraditória relação do homem com o trabalho, e compreendendo bem-estar e mal-estar num continuum de representações (Ferreira, 2012).

Os resultados do estudo evidenciaram diversos aspectos relevantes à gestão da organização, dando direcionamento concreto para a formulação e implementação das estratégias de fortalecimento dos elementos geradores de bemestar no trabalho, bem como de enfrentamento dos causadores ou potencializadores de mal-estar. Construir políticas para as pessoas tendo como base a percepção de quem trabalha parece ser um caminho pertinente na busca pela promoção de qualidade de vida no trabalho.

Destaca-se o que parece ser a principal contribuição do estudo: a de buscar pistas que permitam, do ponto de vista acadêmico, o aprimoramento da teoria sobre a temática e do ponto de vista das organizações, a construção de políticas de gestão de pessoas que possam ser efetivas. Segundo Martins e Molinaro, 2013, p. 1669:

Pensar prospectivamente a nova realidade do mundo do trabalho implica em discutir a equidade nos processos que conformam o campo da gestão do trabalho, a saber: acesso e natureza dos postos de trabalho, proteção social, remuneração, ambiente e condições de trabalho, qualificação, participação política e acesso à tecnologia. 
O número incipiente de estudos sobre bemestar e mal-estar no trabalho dificultou, no caso desta pesquisa, a realização de análises comparativas que permitissem cotejar seus resultados com a literatura. Ademais, a falta de consenso na literatura sobre os construtos também foi elemento dificultador nesse processo por restringir análises teóricas mais profundas acerca do constructo.

Cabe ressaltar que outras investigações podem ser conduzidas por meio do diagnóstico realizado. Uma perspectiva possível para o aprofundamento desta pesquisa sobre a organização do trabalho, que tem se constituído um eixo estruturante de qualidade de vida no trabalho,

\section{REFERÊNCIAS}

Albuquerque, V. P. (2011). Qualidade de Vida no Trabalho, BemEstar e Mal-Estar Sob a Ótica de Trabalhadores de Uma Agência Reguladora Brasileira. Dissertação de mestrado, Programa de Pós-Graduação em Psicologia Social, do Trabalho e das Organizações (PSTO), Universidade de Brasília, Brasília, DF, Brasil.

Andrade, P. P. (2011). Sentimento de (In)justiça na Justiça: Fatores (Des)estruturantes de QVT Sob a Ótica dos Servidores de Um Órgão do Poder Judiciário. Universidade de Brasília, Brasil.

Antloga, C.S.; Avelar, R. (2013). Mal-estar no trabalho. In: Vieira, Mendes e Merlo (orgs.). Dicionário Crítico de Gestão e Psicodinâmica do Trabalho. São Paulo: Juruá Editora.

Antloga, C.S.; Pinheiro, I; Maia, M. M.; Lima, H. K. B. (2014). Mal-estar no trabalho: representações de trabalhadores de um órgão público de pesquisa. Revista Subjetividades, 14 (1), 126-140.

Araújo, J.N.G. (2010). Qualidade de vida no trabalho: controle e escondimento do mal-estar do trabalhador. Trab. Educ. Saúde, 7 (3), 573-585.

Araújo, T. M., Sena, I. P., Viana, M. A., Araújo, E. M. (2006). Mal -estar docente: Avaliação de condições de trabalho e saúde em uma instituição de ensino superior. Revista Baiana de Saúde Pública, 29(1), 6-21. e é uma variável responsável por potencializar sentimentos de bem-estar e ao mesmo tempo de mal-estar do trabalho. Sugere-se ainda a realização de estudos que busquem analisar o fortalecimento das relações socioprofissionais como estratégia operatória de mediação para compensar os desgastes causados por outros fatores organizacionais.

As principais fontes de bem-estar e mal-estar no trabalho com base nas representações de trabalhadores da organização foram identificadas. Além disto, forneceu-se pistas que podem sinalizar caminhos para a busca pelo bem-estar no trabalho no contexto organizacional estudado.

Antunes, R. (1999). Os sentidos do trabalho: Ensaios sobre a afirmação e a negação do trabalho. São Paulo, SP: Boitempo.

Aznar, M. P. M., Rodriguez, M. A. G.; Aznar, M. J. M. (2006). Estrés y malestar en el profesorado. International Journal of Psychology and Psychological Therapy, 6(1), 63-76.

Bauman, Z. (1998). O mal-estar da pós-modernidade. Rio de Janeiro, RJ: Jorge Zahar.

Bendassolli, P. (2011). Mal-estar no trabalho: Do sofrimento ao poder de agir. Revista Mal-estar e Subjetividade, 10(1), 6398.

Boisvert, M. (1980). La qualité de la vie au travail: Regards sur l'expérience québécoise. Ottawa: Agence D'Arcy.

Branquinho, N. G. S. (2010). Qualidade de Vida no Trabalho e vivências de bem-estar e mal-estar no trabalho em professores da rede pública de ensino de Unaí/MG. Dissertação de Mestrado, Programa de Pós-Graduação em Psicologia Social, do Trabalho e das Organizações (PSTO), Universidade de Brasília, Brasília, DF, Brasil.

Brusch, V. L. A.; Monteiro, J.K. (2011). Relações entre colegas como manifestações de resistência ao adoecimento no trabalho. In: J.N.G. de Araújo, C.P.de Almeida, M. C. Ferreira e A. M. Mendes (Orgs.). Dominação e resistência no contexto trabalho-saúde (pp 121-140). São Paulo: Mackenzie. 
Castel, R. (2003). As metamorfoses da questão social: uma crônica ao salário. Petrópolis: Vozes.

Chávez, R. C. (2009). Condiciones de trabajo y bienestar/ malestar docente em profesores de enseñanza media de Santiago de Chile. Educação e Sociedade, 30(107), 409426.

Costa, S. H. B. (2011). Carnaval: Trabalho ou diversão? Atividade, gestão e bem-estar nas escolas de samba do Rio de Janeiro. Tese de Doutorado, Programa de PósGraduação em Psicologia Social, do Trabalho e das Organizações (PSTO), Universidade de Brasília, DF, Brasil.

Dal Rosso, S. (2008). Mais trabalho! A intensificação do labor na sociedade contemporânea. São Paulo: Boitempo.

Daniel, J. B. (2012). "É-feito de coisas burocráticas": Impactos da organização do trabalho na qualidade de vida no trabalho em um órgão público federal. Dissertação de mestrado, Programa de Pós-Graduação em Psicologia Social, do Trabalho e das Organizações (PSTO), Universidade de Brasília, Brasília, DF, Brasil.

Direnzo, M.S.; Greenhaus, J.H. (2011). Job search and voluntary turnover in a boundaryless world: a control theory perspective. Academy of Management Review, 36(3), 567589.

Feitosa, L. R. C. (2010). E se a orquestra desafinar? Contexto de produção e qualidade de vida no trabalho dos músicos da Orquestra Sinfônica de Teresina/PI. Dissertação de Mestrado, Programa de Pós-Graduação em Psicologia Social, do Trabalho e das Organizações (PSTO), Universidade de Brasília, Brasília, Brasil.

Fernandes, L. C. (2013) "Estamos o tempo todo enxugando gelo": Qualidade de vida no trabalho e vivências de bemestar e mal-estar em um órgão do poder judiciário. Dissertação de mestrado, Programa de Pós-Graduação em Psicologia Social, do Trabalho e das Organizações (PSTO), Universidade de Brasília, Brasília, DF, Brasil.

Ferreira, M.C. (2008). A ergonomia da atividade se interessa pela qualidade de vida no trabalho? Reflexões empíricas e teóricas. Cadernos de Psicologia Social e do Trabalho, 11, 83-89.

Ferreira, M.C. (2012). Qualidade de Vida no Trabalho. Uma Abordagem Centrada no Olhar dos Trabalhadores. $2^{\text {a }}$ edição. Paralelo 15.

Ferreira, M. C.; Mendes, A. M. (2003). Trabalho e riscos de adoecimento: 0 caso dos auditores-fiscais da Previdência Social Brasileira. Brasília: Edições Ler, Pensar, Agir (LPA).

Ferreira, M. C.; Seidl, J. (2009). Mal-estar no trabalho: análise da cultura Organizacional de um contexto bancário brasileiro. Revista Psicologia: Teoria e Pesquisa, 25(2), 245-254.

Ferreira, M.C.; Paschoal, T.; Ferreira, R.R. (2013). Qualidade de Vida no Trabalho: Política e Programa para uma empresa de tecnologia da informação. Relatório Técnico. Brasília DF.

Figueira, T.G. (2014). Bem-Estar, Mal-Estar e Qualidade de Vida no Trabalho em uma Instituição Pública Brasileira. Tese de Doutorado, Programa de Pós-Graduação em Psicologia Social, do Trabalho e das Organizações (PSTO), Universidade de Brasília, Brasília, DF, Brasil.

García, M., y Llorens, S. (2003). ¿Influyen los obstáculos laborales en el malestar docente? Fòrum de Recerca, 8. Servei de Publicacions. Universitat Jaume I.

Gil, A. C.; (2009). Estudo de Caso. São Paulo: Atlas.

Gisin, L.; Schulze, H.; Degenhardt, B. (2016). Boundary management as a crucial sucesso factor for flexible-mobile work, demonstrated in the case of home office. In: Deml et al. (orgs). Advances in ergonomic design of systems, products and processes. Springer.

Gomide, S. J.; Silvestrin, L.H.B.; Oliveira, A.F. (2015). Bem-estar no trabalho: o impacto das satisfações com os suportes organizacionais e o papel mediador da resiliência no trabalho. Psicologia: Organizações e Trabalho, 15(1), 1929.

Green, F. (2004). Work intensification, discretion and the decline in well-being at work. Easter Economic Journal, 30(4), 615626.

Günther, H. (2006). Pesquisa qualitativa versus pesquisa quantitativa: esta é a questão? Psicologia: Teoria e Pesquisa, 22(2), 201-210.

Maciel, R. H., Sena, F. C.; Saboia, I. B. (2006). 0 mal-estar nas novas formas de trabalho: um estudo sobre a percepção do papel dos cooperados em uma cooperativa de trabalho autogestionário. Revista Mal-Estar e Subjetividade, 6(2), 535-560.

Maia, M. (2014). "Tribunal da cidadania?! Pra quem?!: Qualidade de vida no trabalho em um órgão do Poder Judiciário brasileiro. Dissertação de mestrado, Programa de Pós-Graduação em Psicologia Social, do Trabalho e das Organizações (PSTO), Universidade de Brasília, Brasília, DF, Brasil.

Martins, M.I.C.; Molinaro, A. (2013). Reestruturação produtiva e seu impacto nas relações de trabalho nos serviços públicos de saúde no Brasil. Ciência e Saúde Coletiva, 18(6), 16671676. 
Medeiros, L. (2012). "Somos a cara da prefeitura? Então somos a cara abandonada": ergonomia da atividade aplicada à qualidade de vida no trabalho no contexto do serviço público municipal. Tese de Doutorado, Programa de PósGraduação em Psicologia Social, do Trabalho e das Organizações (PSTO), Universidade de Brasília, Brasília, DF, Brasil.

Mendes, A.M.; Costa, V.P.; Barros, P.C.R. (2003). Estratégias de enfrentamento do sofrimento psíquico no trabalho bancário. Estudos e Pesquisas em Psicologia, 3(1), 1-11.

Brasil (2012). Resolução 466/2012. Recuperado de http:// conselho.saude.gov.br/resolucoes/2012/Res0466.pdf.

Morin, E.; Tonelli, M.J.; Pliopas, A.L.V. (2007). 0 trabalho e seus sentidos. Psicologia e Sociedade, 19(1), 47-56.

Nogueira, C. V. \& Frota, F. H. S. (2011). Qualidade de vida no trabalho: Percepções sobre sua importância como Política de Valorização no Serviço Público. Revista do Mestrado Profissional em Planejamento em Políticas Públicas, 31-58.

Oliveira, G.S. (2010). Superexploração e mal-estar no trabalho no corte da cana-de-açúcar no Pontal do Paranapanema SP. Revista Pegada, 11(2), 77-94.

Ouriveis, M. (2013). Acumulação flexível, tecnologia e mudanças no mundo do trabalho: da reestruturação produtiva aos home offices. Estudos do Trabalho: 12, 1-23.

Paschoal, T., Torres, C. V.; Porto, J. B. (2010). Felicidade no trabalho: relações com suporte organizacional e suporte social. Revista de Administração Contemporânea (RAC), 14 (6), 1054-1072.

Périco, W.; Justo, J.S. (2011). 0 mal estar no trabalho: a culpa como mal estar e a culpa do mal estar. Revista Mal-Estar e Subjetividade, 11 (1), 135-169.

Pinto, C.L.L.; Goes, R.I.G; Katrein, B.H.; Barreiro, C.B. (2013). Entre o bem e o mal-estar: a intensificação do trabalho docente no âmbito dos Institutos Federais de Educação, Ciência e Tecnologia. Revista Educação por Escrito, 4(1), 44-58.

Pizzio, A.; Klein, K. (2015). Qualidade de vida no trabalho e adoecimento no cotidiano de docentes do ensino superior. Educação e Sociedade, 36 (131), 493-513).

Rauber, A.M.T.R; Rebolo, F. (2011). Trabalho docente: o mal- estar e os desafios da profissão na conquista do prazer, do bem-estar e da felicidade. Anais do IV Seminário Povos Indígenas: saberes tradicionais e formação acadêmica, 1, 1-12

Reinert, M. (1990). Alceste: une methologie d'analyse dês donnees textualles et une application. Em A G. Neval. Bulletin de Méthodologie Sociologique, 28, 24-54.

Reis, B. M. (2013). Trabalho docente e qualidade de vida. Revista Encontro de Pesquisa em Educação, 1(1), 37-48.

Ryan, R.M.; Deci, E.L. (2001). On happiness and human potentials: a review of research on eudaimonic well-being. Annual Review of Psychology, 52, 141-166.

Santos, G.B.; Ceballos, A.G.C. (2013). Bem-estar no trabalho: estudo de revisão. Psicologia em Estudo, 18(2), 247-255.

Santos, L. A. (2014). "Quando chega domingo, fico triste de ter que trabalhar na segunda": A Qualidade de Vida no Trabalho em questão no Serviço Público Federal.

Sennet, R. (1999). A corrosão do caráter: conseqüências pessoais do trabalho no novo capitalismo. Rio de Janeiro, RJ: Record.

Schulte, P; Vainio, H. (2010). Well-being at work - overview and perspective. Scandinavian Journal of Work, Environment \& Health, 36(5), 422-429).

Silva, N. (2005). O mal-estar da professora alfabetizadora: contribuições de D. Winnicot. Revista Mal-Estar e Subjetividade, 5(1), 11-44.

Silva, R.R. (2009). Home officer: um surgimento bem-sucedido da profissão pós-fordista, uma alternativa positiva para os centros urbanos. Revista Brasileira de Gestão Urbana, 1(1), 85-94.

Siqueira, M.M.M.; Padovam, V.A.R. (2008). Bases teóricas de bem-estar subjetivo, bem-estar psicológico e bem-estar no trabalho. Psicologia: Teoria e Pesquisa, 24(2), 201-209.

Timm, E.Z.; Mosquera, J.J.M.; Stobäus, C.D. (2010). 0 mal-estar na docência em tempos líquidos de modernidade. Revista Mal-Estar e Subjetividade, 10(3), 865-885.

Todeschini, R.; Ferreira, M. C. (2013). Olhar de dirigentes sindicais sobre Qualidade de Vida no Trabalho e mal-estar no trabalho. Estudos de Psicologia, 18 (2), 241-247. 
RECONVERSÃO TECNOLÓGICA E QUALIDADE DE VIDA NO TRABALHO (QVT): CASO DE EMPRESA PÚBLICA BRASILEIRA

Veruska Albuquerque Pacheco

RESUMO

Introduzir inovações tecnológicas em organizações implica o desenvolvimento e a adoção de uma nova gestão do trabalho que possibilite harmonizar os novos recursos ou processos com suas possibilidades de uso. O objetivo geral deste estudo foi mapear as percepções de qualidade de vida no trabalho de empregados de uma empresa pública sobre um processo de reconversão tecnológica. Participaram da pesquisa 77 empregados da área de desenvolvimento, vinculados a 6 projetos-piloto. Como instrumentos de coleta de dados, utilizou-se 2 questionários, 2 grupos focais e observações livres e sistemáticas. Os resultados mostraram que, embora globalmente o processo de reconversão tecnológica tenha sido percebido como positivo para os trabalhadores, elementos relacionados à organização e às condições de trabalho, bem como às práticas de gestão precisam ser repensados para proporcionar bem-estar aos trabalhadores e propiciar a eficácia organizacional.

\section{ABSTRACT}

To Introduce technological innovations in organizations requires the development and adoption of a new labor management that allows harmonize the new features or processes with its possibilities of use. The overall goal of this study was to map the quality of work life perceptions of employees of a public company on a technological conversion process. The participants were 77 employees of the development area, linked to six pilot projects. As data collection instruments, were used two questionnaires, two focus groups and free and systematic observations. The results showed that although globally the technological conversion process has been perceived as positive for workers, elements related to the organization and working conditions, as well as management practices need to be rethought to provide well-being to workers and provide the organizational effectiveness.

\section{RESUMEN}

La introducción de innovaciones tecnológicas en las organizaciones requiere el desarrollo y la adopción de una nueva gestión laboral que permite armonizar las nuevas funciones o procesos con sus posibilidades de uso. El objetivo de este estudio fue trazar un mapa de las percepciones de la calidad de vida en el trabajo de los empleados de una empresa pública en un proceso de conversión tecnológica. Los participantes fueron 77 empleados del área de desarrollo, vinculados a seis proyectos piloto. Como instrumentos de recolección de datos, se utilizaron dos cuestionarios, dos grupos focales y observaciones sistemáticas y gratuitas. Los resultados mostraron que aunque globalmente el proceso de conversión tecnológica ha sido percibido como positivo para los trabajadores, elementos relacionados a la organización y a las condiciones de trabajo, así como las prácticas de gestión necesitan ser repensados proporcionar bienestar a los trabajadores y fomentar la eficacia de la organización.
PALAVRAS-CHAVE:

Reconversão tecnológica; método ágil; qualidade de vida no trabalho; empresa pública.

KEYWORDS:

Technological conversion; agile method; quality of work life; public company.

PALABLAS CLAVE:

Conversión tecnológica; método ágil; calidad de la vida laboral; empresa pública. 


\section{INTRODUÇÃO}

Desde o advento da Revolução Industrial no século XVIII, passando pela reestruturação produtiva, em meados da década de 1970, o mundo do trabalho vem sofrendo mudanças vultosas. Tais mudanças têm acarretado sérias consequências para os trabalhadores: intensificação e precarização do trabalho, informalização do emprego, acidentes, problemas físicos e psíquicos de saúde, entre outros (De Toni, 2006; Navarro e Padilha, 2007).

Diante desse contexto, alguns elementos são importantes para a reflexão sobre o trabalho contemporâneo especialmente desde o advento da reestruturação produtiva. Inicialmente, ressaltam-se os avanços científicos e tecnológicos que tanto impactam no trabalho e nas profissões, demandando do trabalhador, entre outras características, flexibilidade, resiliência e abertura a mudanças (Ferreira, 2012; Leite, 1994). Para Decca (1988), os avanços que se sucederam em nome do progresso acabaram por se transformar em mecanismos de controle social.
Outro aspecto relevante é a discussão sobre a centralidade do trabalho em um contexto em que o trabalho perde o sentido, aliena ou conduz ao estranhamento (Marx, 1989; Ranieri, 2001). Há que se considerar ainda a questão econômica que permeia esse trabalho, em uma sociedade capitalista, amparada em uma política neoliberal que media as relações entre o estado e o capital (Ouriveis, 2013).

Diante do pano de fundo apresentado se intensificaram os estudos sobre Qualidade de Vida no Trabalho (QVT) e seus impactos na saúde dos trabalhadores. A origem da QVT se deu na década de 1950 com os estudos da escola sociotécnica de Eric Trist e colaboradores. (Albuquerque, 2011; Rodrigues, 2011). Também são pioneiros de avaliação da QVT Walton (1973), Hackman e Oldham (1974), Westley (1979), Werther e Davis (1983) e Nadler e Lawler (1983). A Figura 1 sintetiza as principais características desses enfoques de QVT, considerados clássicos e ainda bastante referenciados na literatura.

\begin{tabular}{|c|c|}
\hline Autor & Principais traços do modelo \\
\hline Walton (1973) & $\begin{array}{l}\text { Enfatiza o trabalho como um todo, mencionando também aspectos da vida fora do } \\
\text { trabalho. } \\
\text { Fatores de QVT: compensação justa e adequada; condições de trabalho; uso ou } \\
\text { desenvolvimento das capacidades; oportunidade de crescimento e segurança; integração } \\
\text { social na organização; constitucionalismo; trabalho e vida; e relevância social. }\end{array}$ \\
\hline Hackman e Oldham (1974) & $\begin{array}{l}\text { Aponta três estados psicológicos críticos que influenciam na motivação no ambiente } \\
\text { laboral: conhecimento e resultados do seu trabalho; responsabilidade percebida pelos } \\
\text { resultados do seu trabalho; significância percebida do seu trabalho. }\end{array}$ \\
\hline Westley (1979) & $\begin{array}{l}\text { A QVT existe quando há a humanização dos postos de trabalho a ponto de minimizar } \\
\text { quatro problemáticas: insegurança (instabilidade no emprego); injustiça (desigualdade } \\
\text { salarial); alienação (baixa autoestima); e anomia (carência de legislação trabalhista). }\end{array}$ \\
\hline Whertey e Davis (1981) & $\begin{array}{l}\text { QVT tem relação direta com fatores ambientais (habilidades, disponibilidade e } \\
\text { expectativas sociais), organizacionais (eficiência) e comportamentais (autonomia, } \\
\text { variedade, identidade da tarefa e retroinformação) do cargo. }\end{array}$ \\
\hline Nadler e Lawler (1983) & $\begin{array}{l}\text { Apresenta seis contextos distintos com as concepções de QVT ao longo do tempo (como } \\
\text { variável, como abordagem, como método, como movimento, como tudo, como nada). }\end{array}$ \\
\hline
\end{tabular}

Figura 1. Comparação dos modelos clássicos de qualidade de vida no trabalho 


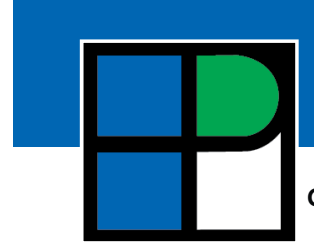

Grupo de Estudos Pesquisas em

Mesmo sendo um constructo em estudo a algumas décadas, vários autores apontam para uma imprecisão conceitual sobre a qualidade de vida no trabalho, abrangendo elementos como saúde, segurança, relações de trabalho, estresse e humanização (Bragard, Dupuis, Razavi, Reynaert e Etienne, 2012; Brunalt, Fouquereau, Colombat, Gillet, El-Hage, Camus e Gaillard, 2013; Ferreira, 2012; Josiah, Odera, Chepkuto e Okaka, 2012; Lacaz, 2000; Lawler, 1982; Nadler e Lawler, 1983; Nayeri, Salehi e Noghabi, 2011; Sampaio, 2012).

O conceito de qualidade de vida no trabalho adotado neste estudo, cujo aporte teórico metodológico é o da Ergonomia da Atividade Aplicada à Qualidade de Vida no Trabalho (EAA_QVT) é o de Ferreira (2012), onde QVT pode ser compreendida sob duas perspectivas: Sob a ótica das organizações, QVT representa normas, diretrizes e práticas que visam à promoção do bem-estar individual e coletivo, o desenvolvimento pessoal dos trabalhadores e o exercício da cidadania organizacional. Sob a ótica dos trabalhadores, QVT resulta em representações que estes constroem da organização na qual estão inseridos, indicando o predomínio de vivências de bem-estar no trabalho, de reconhecimento institucional e coletivo, de possibilidade de crescimento profissional e de respeito às características individuais.

Diante do exposto até aqui, o objetivo geral deste estudo foi mapear as percepções de qualidade de vida no trabalho de empregados de uma empresa pública sobre um processo de reconversão tecnológica intitulada "Método Ágil de Entrega de Soluções".

Com base em um macrodiagnóstico de QVT realizado na empresa, identificou-se fatores negativos que indicaram risco de adoecimento dos trabalhadores da empresa, evidenciando a necessidade de se investigar de forma mais aprofundada seus impactos na QVT. Os fatores centrais das representações negativas do grupo estão relacionados com os fatores organização do trabalho e práticas de gestão. Os resultados indicaram ainda questões relacionadas à comunicação nas relações socioprofissionais de trabalho e nas ferramentas colaborativas.

Após a realização do macrodiagnóstico na organização, surgiu da direção superior da empresa a demanda de implantação de uma nova abordagem de trabalho, intitulada "Métodos Ágeis" ou "Metodologia Ágil". Na organização estudada, o projeto foi intitulado "Método Ágil de Entrega de Soluções".

Considerando os resultados do macrodiagnóstico, a hipótese geral delineada, do tipo descritiva (Cooper e Schindler, 2003; Gressler, 2004), foi a seguinte: A percepção global dos trabalhadores acerca da implantação do método ágil é positiva, mas existem fatores relacionados à organização do trabalho que podem obstaculizar as atividades e impactar negativamente na qualidade de vida no trabalho.

Os métodos ágeis de desenvolvimento de software foram introduzidos por meio do Manifesto Ágil, publicado nos Estados Unidos em 2001 por 17 desenvolvedores e metodologistas. O conteúdo do manifesto abrange valores, princípios e práticas que visam garantir melhores resultados para os projetos de desenvolvimento, e a abordagem tem se tornado popular a partir de então (Melo e Ferreira, 2010). 
Segundo Fagundes (2005), os valores que norteiam o "Manifesto Ágil" são:

- Os indivíduos e as interações valem mais que os processos e as ferramentas.

- Um software que funciona vale mais que uma vasta documentação.

- O cliente colaborando vale mais que o contrato negociado.

- Responder às mudanças vale mais que acompanhar um plano.

Fagundes (2005, p. 20-21) apresenta ainda uma coleção de doze princípios (grifos nossos) aos quais os métodos ágeis devem se adequar:

a) A prioridade é satisfazer ao cliente através de entregas de software de valor contínuas e frequentes.

b) Receber bem as mudanças de requisitos, mesmo em uma fase avançada, dando aos clientes vantagens competitivas.

c) Entregar softwares em funcionamento com frequência de algumas semanas ou meses, sempre na menor escala de tempo.

d) As equipes de negócio e desenvolvimento devem trabalhar juntas diariamente durante todo o projeto.

e) Manter uma equipe motivada fornecendo ambiente, apoio e confiança necessários para a realização do trabalho.

f) A maneira mais eficiente da informação circular dentro da equipe é através de uma conversa face-a-face.

g) Ter o software funcionando é a melhor medida de progresso

h) Processos ágeis promovem o desenvolvimento sustentável. Todos envolvidos devem ser capazes de manter um ritmo de desenvolvimento constante.

i) Atenção contínua a excelência técnica e um bom projeto aumentam a agilidade.

j) Simplicidade é essencial.

k) As melhores arquiteturas, requisitos e projetos provêm de equipes organizadas.

I) Em intervalos regulares, a equipe deve refletir sobre como se tornar mais eficaz e então se ajustar para adaptar seu comportamento.

Os termos em destaque nos princípios evidenciam uma filosofia que tem como foco melhoria dos processos, aumento de resultados e velocidade na entrega dos produtos. Por trás desses princípios, parece razoável supor que os métodos ágeis implicam em intensificação do trabalho e mudanças significativas na organização do trabalho.

Considerando as premissas da metodologia e as mudanças que são subjacentes à sua implantação, acredita-se, portanto, que a sua inserção na empresa poderá impactar radicalmente o trabalho e, consequentemente, a percepção dos fatores estruturantes de QVT dos funcionários envolvidos.

No que se refere à inserção de novos métodos de trabalho, a literatura (Brusiquese e Ferreira, 2012; Rebecchi, 1990; Van de Ven, 1986) já apontou que implantação de novas tecnologias impacta especialmente na organização do trabalho. Ressalta-se, aqui, que o fator organização do trabalho foi considerado como crítico no diagnóstico macroergonômico de QVT realizado na instituição pesquisada.

Assim, tendo em vista o macrodiagnóstico de QVT e o cenário de implantação do Método Ágil de Entrega de Soluções na empresa é importante analisar os impactos que a inserção do método terá na tríade indivíduo/trabalho/organização e que consequentemente refletirão na QVT desses trabalhadores, especialmente na organização do trabalho e nas práticas de gestão da empresa. Entende-se que, para verificar melhor esses impactos, a realização de uma pesquisa multimétodo seja pertinente, por investigar, à luz de ferramentas diversas o objeto de estudo, razão pela qual a ação ergonômica se mostra como metodologia adequada ao estudo. 


\section{MÉTODO}

Trata-se de um estudo qualitativo e quantitativo (Gunther, 2006; Landim, Lourinho, Lira e Santos, 2006) caracterizado como um estudo de caso (Gil, 2009; Yin, 2005). O estudo está ancorado no nível microergonômico do modelo teórico descrito na abordagem denominada Ergonomia da Atividade Aplicada à Qualidade de Vida no Trabalho, proposta por Ferreira (2012).

A operacionalização da pesquisa se baseou nos fundamentos epistemológicos da Análise Ergonômica do Trabalho (Guérin et al., 2001; Wisner, 2004). A ação ergonômica, via de regra, decorrente de uma demanda, pressupõe algumas fases e etapas a serem cumpridas, mas cuja construção pode ser delineada à medida que as ações são realizadas. Os autores defendem que a transformação do trabalho é finalidade central da ação ergonômica, e que essa transformação deve contribuir em duas perspectivas: i) Para a concepção de situações de trabalho que não causem prejuízos à saúde de quem trabalha, possibilitando o exercício de suas competências com possibilidades de valorização; ii) para o alcance dos objetivos organizacionais.

Ferreira (2012, p. 155) destaca o papel a ergonomia enquanto uma ciência que vem sendo utilizada para atender a demandas diversas do mundo do trabalho:

A ergonomia estuda a atividade para compreender o seu grau de adequação ou a forma de o indivíduo interagir com o meio que o circunda. Nesta perspectiva, os efeitos da atividade trabalho constituem uma dimensão analítica privilegiada da ergonomia, tanto pelos efeitos positivos (objetivos quantitativos $e$ qualitativos obtidos, desenvolvimento de competências), quanto pelos negativos (agravos à saúde, vivências de sofrimento, erros, incidentes, retrabalho).
A ergonomia da atividade, como uma disciplina por concepção multidisciplinar, compreende um vasto campo de atuação, onde a temática da qualidade de vida no trabalho se insere pertinentemente, já que o seu perfil fornece fundamentos teóricos que permitem a ampliação de seu campo de ação, conforme argumenta Ferreira (2012).

\section{Campo de Pesquisa}

A pesquisa realizou-se em uma empresa pública brasileira vinculada ao poder executivo federal, que foi criada com o objetivo de modernizar e dar agilidade a setores estratégicos da administração pública brasileira.

A missão da empresa é disponibilizar informações e prover soluções tecnológicas para o êxito da gestão do Estado em atendimento à sociedade brasileira. Sua visão preconiza ser um centro de informações e soluções tecnológicas para o Brasil.

Um amplo conjunto de produtos e serviços é oferecido pela instituição: informações de governo aberto; soluções de tecnologia da informação; consultoria em tecnologia da informação; sistemas estruturadores do Governo Federal; segurança da informação; e sistemas de tecnologia da informação para uma rede logística nacional inteligente.

\section{Participantes}

Participaram do estudo 77 empregados $^{1}$ que integraram 6 projetos pilotos em 5 cidades diferentes, cujo perfil demográfico encontra-se descrito na Tabela1. 
Tabela 1:

Descriçáo do perfil demográfico dos participantes

\begin{tabular}{|c|c|c|c|c|}
\hline Projeto & & & $\begin{array}{l}\text { Média de } \\
\text { idade }\end{array}$ & $\begin{array}{c}\text { Tempo médio de } \\
\text { serviço na empresa } \\
\text { (anos) }\end{array}$ \\
\hline Alfa & $\begin{array}{c}\text { Homens } \\
8\end{array}$ & $\begin{array}{c}\text { Mulheres } \\
2\end{array}$ & 35 & 4 \\
\hline Beta & $\begin{array}{c}\text { Homens } \\
8 \\
\end{array}$ & $\begin{array}{c}\text { Mulheres } \\
1\end{array}$ & 33 & 5 \\
\hline Gama & $\begin{array}{c}\text { Homens } \\
10\end{array}$ & $\begin{array}{c}\text { Mulheres } \\
0\end{array}$ & 35 & 8 \\
\hline Sigma & $\begin{array}{c}\text { Homens } \\
13\end{array}$ & $\begin{array}{c}\text { Mulheres } \\
0\end{array}$ & 38 & 9 \\
\hline Delta & $\begin{array}{c}\text { Homens } \\
14\end{array}$ & $\begin{array}{c}\text { Mulheres } \\
3\end{array}$ & 42 & 10 \\
\hline Zeta & $\begin{array}{c}\text { Homens } \\
18\end{array}$ & $\begin{array}{c}\text { Mulheres } \\
0\end{array}$ & 34 & 3 \\
\hline Total & 71 & 6 & 36,6 & 6,5 \\
\hline
\end{tabular}

Instrumentos de Coleta de Dados

A Figura 2 descreve os instrumentos utilizados na presente pesquisa, bem como seus objetivos e os grupos/projetos que participaram de cada uma.
Ressalta-se que, em função da limitação de recursos financeiros e de tempo, a gestão da instituição optou por não aplicar todos os instrumentos nos seis projetos, cujas equipes são lotadas em diferentes regionais.

\begin{tabular}{|c|c|c|c|}
\hline $\begin{array}{l}\text { Período de } \\
\text { Aplicação }\end{array}$ & Instrumento & Descrição do Instrumento & Participantes \\
\hline $\begin{array}{l}\text { Antes da } \\
\text { implantação do } \\
\text { método }\end{array}$ & $\begin{array}{l}\text { Questionário de } \\
\text { expectativas }\end{array}$ & $\begin{array}{l}\text { Identificar globalmente as expectativas globais } \\
\text { positivas e negativas em relação ao método e } \\
\text { especificamente em relação aos fatores organização do } \\
\text { trabalho, práticas de gestão e comunicação. }\end{array}$ & Todos os projetos \\
\hline \multirow{3}{*}{$\begin{array}{l}\text { Durante a } \\
\text { implantação do } \\
\text { método }\end{array}$} & $\begin{array}{l}\text { "Termômetro de } \\
\text { QVT" }\end{array}$ & $\begin{array}{l}\text { Instrumento de mapeamento da percepção diária de } \\
\text { QVT, das fontes de bem-estar e de mal-estar no } \\
\text { trabalho. }\end{array}$ & Todos os projetos \\
\hline & Grupo Focal 1 & $\begin{array}{l}\text { Mapear percepções, quanto à implantação do método, } \\
\text { sobre os problemas, consequências, estratégias de } \\
\text { enfrentamento e possíveis soluções. }\end{array}$ & $\begin{array}{l}\text { Projetos Alfa, } \\
\text { Sigma e Zeta }\end{array}$ \\
\hline & $\begin{array}{l}\text { Observações livres } \\
\text { e sistemáticas }\end{array}$ & $\begin{array}{l}\text { Livre: descrição da crônica da atividade, } \\
\text { desenvolvendo o fluxo das atividades de trabalho. } \\
\text { Sistemática: identificação, com base em um recorte } \\
\text { de uma situação, das estratégias de mediação } \\
\text { individuais e coletivas desenvolvidas para lidar com } \\
\text { o custo humano no trabalho. }\end{array}$ & $\begin{array}{l}\text { Projetos Alfa, } \\
\text { Sigma e Zeta }\end{array}$ \\
\hline $\begin{array}{l}\text { Depois da } \\
\text { implantação do } \\
\text { método }\end{array}$ & Grupo Focal 2 & $\begin{array}{l}\text { Mapear as percepções dos empregados sobre o que } \\
\text { melhorou e o que piorou no seu trabalho com a } \\
\text { implantação do método. }\end{array}$ & $\begin{array}{l}\text { Projetos Alfa, } \\
\text { Sigma e Zeta }\end{array}$ \\
\hline
\end{tabular}

Figura 2. Descrição dos instrumentos utilizados na Análise Ergonômica do Trabalho 
Procedimentos de coleta e tratamento

Proferiram-se palestras a todos os trabalhadores dos projetos, sendo uma presencial (Projeto Zeta), quatro por áudio conferência (Projetos Alfa, Gama, Sigma e Delta) e uma por videoconferência (Projeto Beta). Nesta oportunidade, esclareceram-se os objetivos da pesquisa e explicitaram-se as etapas e instrumentos de coleta de dados. Constatou-se uma explícita aceitação dos empregados dos instrumentos e da proposta de calendário apresentada. A Figura 3 descreve os procedimentos de coleta de cada instrumento.

\begin{tabular}{|c|c|c|c|c|}
\hline Instrumento & Procedimentos & Período de aplicação & $\begin{array}{c}\% \text { de } \\
\text { participação }\end{array}$ & $\begin{array}{l}\text { Tratamento } \\
\text { dos Dados }\end{array}$ \\
\hline $\begin{array}{l}\text { Questionário de } \\
\text { expectativas }\end{array}$ & $\begin{array}{l}\text { Questionário on line aplicado } \\
\text { via docs.google. }\end{array}$ & - 30/09 a 15/10/2014 & $87,01 \%$ & $\begin{array}{l}\text { Estatística } \\
\text { descritiva }\end{array}$ \\
\hline $\begin{array}{l}\text { Termômetro de } \\
\text { QVT }\end{array}$ & $\begin{array}{l}\text { Questionário on line aplicado } \\
\text { via docs.google. Diariamente, } \\
\text { os empregados recebiam email } \\
\text { com o link para acessar o } \\
\text { termômetro. }\end{array}$ & - 30/09 a 04/12/2016 & $59,23 \%$ & $\begin{array}{l}\text { Estatística } \\
\text { descritiva }\end{array}$ \\
\hline Grupo Focal 1 & $\begin{array}{l}\text { Realizado presencialmente, nas } \\
\text { unidades de cada unidade. } \\
\text { Conduzido em } 3 \text { etapas: } \\
\text { individual/subgrupo/síntese do } \\
\text { grupo. Duração média de cada } \\
\text { grupo focal: } 2 \mathrm{~h} \text {. }\end{array}$ & $\begin{array}{ll} & \text { 29/10/2014 (Projeto Alfa) } \\
\text { 04/11/2014 (Projeto Sigma) } \\
\text { - } 13 / 11 / 2014 \text { (Projeto Zeta) }\end{array}$ & $100 \%$ & $\begin{array}{l}\text { Análise de } \\
\text { conteúdo } \\
\text { categorial } \\
\text { temática }\end{array}$ \\
\hline $\begin{array}{l}\text { Observações livres } \\
\text { e sistemáticas }\end{array}$ & $\begin{array}{l}\text { Realizado presencialmente, nas } \\
\text { unidades de cada projeto. }\end{array}$ & $\begin{array}{ll} & \text { 29/10/2014 (Projeto Alfa) } \\
& \text { 04/11/2014 (Projeto Sigma) } \\
& 13 / 11 / 2014 \text { (Projeto Zeta) }\end{array}$ & - & $\begin{array}{l}\text { Análise de } \\
\text { conteúdo } \\
\text { categorial } \\
\text { temática }\end{array}$ \\
\hline Grupo Focal 2 & $\begin{array}{l}\text { Realizado presencialmente, nas } \\
\text { unidades de cada projeto. } \\
\text { Conduzido em } 3 \text { etapas: } \\
\text { individual/subgrupo/síntese do } \\
\text { grupo. Duração média de cada } \\
\text { grupo focal: } 2 \text { horas. }\end{array}$ & $\begin{array}{ll} & 11 / 12 / 2014 \text { (Projeto Sigma) } \\
- & 12 / 12 / 2014 \text { (Projeto Alfa) } \\
& \text { 20/01/2015 (Projeto Zeta) }\end{array}$ & $100 \%$ & $\begin{array}{l}\text { Análise de } \\
\text { conteúdo } \\
\text { categorial } \\
\text { temática }\end{array}$ \\
\hline
\end{tabular}

Figura 3. Descrição dos procedimentos de coleta e tratamento de dados

Ao final de todo o processo de coleta, realizou-se uma reunião de validação dos resultados com os participantes da pesquisa, via videoconferência, para apresentação de todos os resultados. O objetivo foi aprimoramento da qualidade dos dados obtidos durante a AET, com vistas à apresentação clara da realidade de trabalho dos empregados com a reconversão tecnológica feita por meio do uso do "Método Ágil".

\section{RESULTADOS}

\section{Questionário de expectativas}

No questionário de expectativas, os respondentes deveriam atribuir uma pontuação de 1 a 10 (no qual 0 correspondia a percepção muito negativa e 10 correspondia à percepção muito positiva) para as suas expectativas em relação aos seguintes aspectos: expectativa global em relação ao método ágil; expectativas em relação à 
organização do trabalho, às condições de trabalho, às relações socioprofissionais e às práticas de gestão. Havia, ainda, dois campos abertos para descrição das principais expectativas positivas e pelos grupos.

Tabela 2:

Médias por fator e média geral do questionário de expectativas

\begin{tabular}{lccccc}
\hline Projeto & Adoçāo do Ágil & $\begin{array}{c}\text { Organizaçāo do } \\
\text { Trabalho }\end{array}$ & $\begin{array}{c}\text { Condiçōes de } \\
\text { Trabalho }\end{array}$ & $\begin{array}{c}\text { Relaçōes } \\
\text { Socioprofissionais }\end{array}$ & $\begin{array}{c}\text { Práticas de } \\
\text { Gestāo }\end{array}$ \\
\hline Projeto Alfa & 7,6 & 7,2 & 6,1 & 7,9 & 8,0 \\
Projeto Sigma & 7,6 & 7,6 & 7 & 7,6 & 7,8 \\
Projeto Zeta & 8,7 & 8,2 & 7,5 & 8,3 & 8,7 \\
Projeto Gama & 8,4 & 7,3 & 7,5 & 8,3 & 7,8 \\
Projeto Beta & 7,4 & 6,1 & 6,2 & 7,6 & 7,6 \\
Projeto Delta & 7,4 & 6,1 & 6,2 & 7,6 & 7,6 \\
\hline Média geral & 8,1 & 7,4 & 7,1 & 8,0 & 8,1 \\
\hline
\end{tabular}

Em relação às questões abertas, a Figura 4 negativas em relação à adoção do método ágil na apresenta as principais expectativas positivas e empresa.

\begin{tabular}{|c|c|c|c|}
\hline \multicolumn{2}{|c|}{ Expectativas Positivas } & \multicolumn{2}{c|}{ Expectativas Negativas } \\
\hline Nome do Núcleo & $\begin{array}{c}\text { Qtde. de } \\
\text { Verbalizações }\end{array}$ & $\begin{array}{c}\text { Qtde. de } \\
\text { Verbalizações }\end{array}$ \\
\hline Melhoria dos processos de trabalho & $44(26 \%)$ & $\begin{array}{c}\text { Método e gestão inadequada do } \\
\text { método }\end{array}$ & $47(50 \%)$ \\
\hline $\begin{array}{c}\text { Melhor integração entre áreas e } \\
\text { equipes }\end{array}$ & $35(21 \%)$ & $\begin{array}{c}\text { Resistência e não-adaptação dos } \\
\text { empregados }\end{array}$ & $19(20 \%)$ \\
\hline $\begin{array}{c}\text { Maior autonomia e } \\
\text { responsabilidade }\end{array}$ & $28(17 \%)$ & Pressão por resultados e sobrecarga & $13(14 \%)$ \\
\cline { 1 - 1 } Produtividade, valor e qualidade & $22(13 \%)$ & Nenhuma & $10(11 \%)$ \\
\cline { 1 - 2 } $\begin{array}{c}\text { Aproximação com o cliente } \\
\text { Mais motivação e satisfação }\end{array}$ & $21(13 \%)$ & Modificação do layout & $5(5 \%)$ \\
\hline $\begin{array}{c}\text { Aprendizado e desenvolvimento } \\
\text { profissional }\end{array}$ & $4(2 \%)$ & & \\
\cline { 1 - 2 } & & &
\end{tabular}

Figura 4. Principais expectativas positivas e negativas

\section{"Termômetro de QVT"}

O "termômetro" objetivou mapear como os participantes dos pilotos percebiam sua QVT dia a dia, atribuindo uma nota de 0 a 10 (no qual 0 correspondia à mal-estar e 10 correspondia à bemestar) para seu sentimento predominante em relação ao método ágil. O instrumento possuía ainda dois campos abertos, para identificação da principal fonte de bem-estar e da principal fonte de mal-estar naquele dia. A Tabela 3 apresenta o resultado global do termômetro, indicando a média acumulada em cada um dos projetos. 
Tabela 3:

Resultado Geral do Termômetro de QVT

\begin{tabular}{lccc}
\hline Projeto & $\begin{array}{c}\text { Média Atribuída } \\
\text { (acumulada) }\end{array}$ & $\begin{array}{c}\text { \% de Respondentes } \\
\text { (acumulado) }\end{array}$ & $\begin{array}{c}\text { Dias de } \\
\text { Pesquisa }\end{array}$ \\
\hline Projeto Gama & 7,68 & 61,74 & 48 \\
Projeto Sigma & 7,14 & 64,30 & 53 \\
Projeto Zeta & 7,08 & 57,36 & 55 \\
Projeto Alfa & 6,59 & 71,03 & 58 \\
Projeto Beta & 5,70 & 52,72 & 47 \\
Projeto Delta & 5,44 & 48,20 & 36 \\
\hline Geral & 6,61 & 59,23 & - \\
\hline
\end{tabular}

\section{Grupo Focal 1}

Abordou-se quatro questões no grupo focal: 1. Quando penso no meu trabalho no método Ágil, o principal problema existente é...; 2. Esse problema provoca como consequência principal...; 3. Para enfrentar tais consequências (evitar, prevenir, atenuar), eu faço...; 4. Para resolver tal problema, julgo importante realizar... A Figura 5 apresenta, para cada uma das questões, os temas e tópicos discutidos durante a coleta de dados.

\begin{tabular}{|c|c|}
\hline Tema & Principais tópicos relatados pelos participantes \\
\hline $\begin{array}{c}\text { Principais problemas identifica- } \\
\text { dos na implantação do Método } \\
\text { Ágil }\end{array}$ & $\begin{array}{l}\text { Trabalho em projetos paralelos prejudica o andamento do trabalho. } \\
\text { Os diferentes níveis de maturidade, experiência e de entendimento dos conceitos e papéis } \\
\text { dos empregados na metodologia. } \\
\text { As estimativas das tarefas e prazos foram superestimados. } \\
\text { As dificuldades em administrar a autogestão e em dividir papéis. } \\
\text { - } \text { As excesso de reuniões, algumas cansativas e improdutivas. } \\
\text { As alterações constantes nos requisitos (instabilidade). } \\
\text { A redundância de esforços em decorrência do ALM². }\end{array}$ \\
\hline $\begin{array}{l}\text { Principais consequências para } \\
\text { os problemas encontrados }\end{array}$ & $\begin{array}{l}\text { A falta de maturidade do time gerou expectativas superestimadas quanto à produtividade } \\
\text { e muitos riscos não foram identificados. } \\
\text { Sobrecarga, especialmente em função do excesso de controle e duplicação de registros no } \\
\text { sistema "ALM". Preocupação excessiva em compatibilizar os registros de horas nas ativi- } \\
\text { dades do ALM com o controle de frequência. } \\
\text { Desconforto psicológico e frustração em função de metas e prazos não atingidos: estresse, } \\
\text { desmotivação, cansaço, desgaste nos relacionamentos, insatisfação, incerteza quanto ao } \\
\text { futuro. } \\
\text { Diminuição da produtividade. }\end{array}$ \\
\hline $\begin{array}{l}\text { Estratégias utilizadas para en- } \\
\text { frentar (evitar, prevenir, atenu- } \\
\text { ar) as consequências }\end{array}$ & $\begin{array}{l}\text { Assumir carga de trabalho maior, por meio de horas-extras. } \\
\text { Promover discussões em equipe para lidar com as questões/dificuldades propiciando o } \\
\text { desenvolvimento de propostas alternativas. } \\
\text { Amadurecer a autogestão. } \\
\text { Empreender mais esforços para alinhar e reestimar expectativas entre equipe, cliente e a } \\
\text { área de negócios. } \\
\text { Priorizar o projeto ágil, deixando projetos paralelos em segundo plano, o que pode causar } \\
\text { insatisfação em outros clientes e sobrecarga de outros colegas. } \\
\text { "Quebrar" atividades em tarefas menores. } \\
\text { Estudar artefatos de outros projetos. }\end{array}$ \\
\hline
\end{tabular}




\begin{tabular}{|c|c|}
\hline Tema & Principais tópicos relatados pelos participantes \\
\hline $\begin{array}{l}\text { Sugestões para resolução dos } \\
\text { problemas apontados }\end{array}$ & 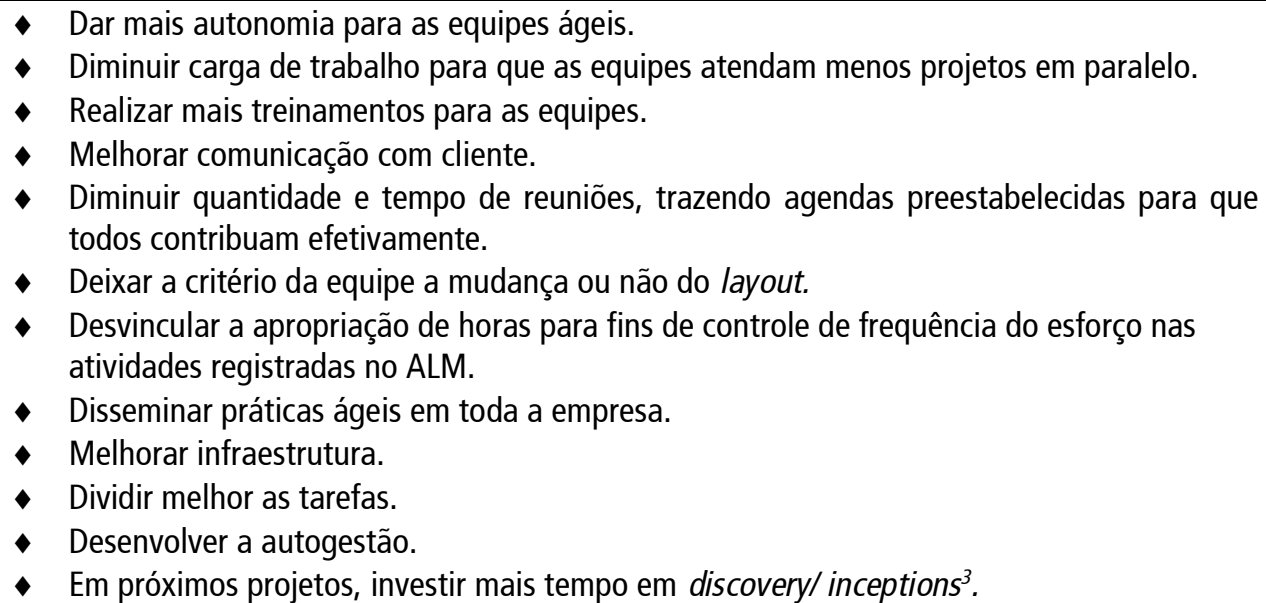 \\
\hline
\end{tabular}

Figura 5. Resultados do Grupo Focal 1

Houve boa receptividade e envolvimento na realização dos grupos focais. Em todas as aplicações, o ambiente foi amistoso e os grupos envolveram-se e participaram ativamente da atividade. Ficou evidente durante a realização da coleta, a importância do espaço de fala.

Durante as discussões, em vários momentos os grupos deixaram claro que não veem problemas em si mesmo no método ágil. O método prevê a antecipação de problemas e a adaptação do time e das tarefas ao longo do projeto. Entretanto, há uma pressão em relação a prazos e datas que não dão espaço à flexibilização. Tal limite está mais relacionado com o modo de implantação do método.

Os participantes relataram que alguns membros perderam o treinamento realizado sobre o método. Outros entraram no grupo após o início do piloto. Tais problemas geraram alguns descompassos no início das atividades.

O grupo demonstrou preocupação em como seriam vistos pela gestão superior se não conseguissem cumprir as metas estabelecidas.
Entretanto, ficou evidenciada uma percepção geral de que a experiência adquirida minimizará futuramente os problemas existentes.

\section{Observações livres e sistemáticas}

A. Observação livre. Constatou-se alguns traços comuns aos três pilotos onde aconteceram as observações:

- Divisória entre as estações de trabalho baixa, facilitando a interação entre os empregados.

- Ausência de queixas sobre Iluminação e temperatura do ambiente.

- Rede de colaboração entre os empregados: com frequência, há deslocamento de um empregado para a estação de trabalho do outro, para sanar dúvidas ou ajudar em algum problema de trabalho.

- Relacionamento entre pares amistoso, tratamento cordial. 
- Acesso paralelo a vários sistemas e sites, como: Java Behave, Expresso, Pidgin, ALM, Você.'Empresa', e-mail pessoal, sites de banco, notícias, etc.

- Personalização das estações de trabalho fotos da família, objetos pessoais e enfeites diversos, dando um traço pessoal a cada estação.

\section{A. Observação sistemática.}

Durante a observação livre, identificou-se três problemas centrais para serem observados mais profundamente:

- Interação entre as áreas: membros dos times precisavam solicitar liberação de acesso ao banco de dados, que dependia de autorização de outra unidade. Em um dos casos, um membro permaneceu ao telefone por mais de duas horas esperando tal liberação.

- Estimativa de prazos pela equipe: apesar das reuniões antes do início do piloto, o grupo percebeu que as estimativas para cumprimento dos prazos foram subestimadas, gerando a necessidade de horas-extras e cancelamento de férias de alguns membros.

- Mecanismos de controle: as informações relativas ao andamento das atividades eram realizadas em duas ferramentas distintas, gerando retrabalho e redundância de informações.

\section{Grupo Focal 2}

Nessa etapa, foram discutidas cinco questões, onde os participantes atribuíram notas de 0 a 10 para a implantação do método e para os fatores organização do trabalho, condições de trabalho, relações socioprofissionais e práticas de gestão. Conforme já apresentado, estes foram os aspectos cuja avaliação da pesquisa anterior, realizada na empresa, demonstraram mais vivências de mal-estar. Nesse sentido, objetivou-se avaliar se o grupo percebeu melhorias nos aspectos em questão a partir da implantação do novo método de trabalho.

As seguintes questões estruturaram a condução do grupo focal: 1) Minha nota global para a implantação do método Ágil na Empresa é... (0 10). Justifique; 2. Minha nota global para a Organização do Trabalho é... (0 - 10). Justifique; 3. Minha nota global para as Condições do Trabalho é... (0 - 10). Justifique; 4. Minha nota global para as Relações Socioprofissionais é... (0 - 10). Justifique; 5. Minha nota global para as Práticas de Gestão é... (0 - 10). Justifique. As justificativas foram trabalhadas pelos grupos identificando aspectos positivos e negativos em cada um dos quesitos. As figuras $6,7,8,9$ e 10 descrevem os principais resultados. 


\begin{tabular}{|l|l|}
\hline Percepção Global do "Método Ágil" (Média: 7,22) \\
\hline Aspectos positivos percebidos & Aspectos negativos percebidos \\
\hline $\begin{array}{l}\text { Proximidade com o cliente } \\
\text { Uso de coaching }\end{array}$ & $\begin{array}{l}\text { Pouco acompanhamento do GT Ágil } \\
\text { Comprometimento da equipe e envolvimento de } \\
\text { diversas áreas da empresa } \\
\text { Qualidade do produto final } \\
\text { Patrocínio da diretoria }\end{array}$ \\
Maior agilidade no trabalho na infra & $\begin{array}{l}\text { Falta de alinhamento dos coachs com a realidade da } \\
\text { empresa e ausência de acompanhamento para o DevOps }\end{array}$ \\
& $\begin{array}{l}\text { Forma inadequada de repasse do sistema legado para a } \\
\text { equipe }\end{array}$ \\
& $\begin{array}{l}\text { Falta de complementação dos treinamentos com oficinas } \\
\text { técnicas } \\
\text { Perda do foco no trabalho decorrente de interferências } \\
\text { (palestras, reuniões, questionários) }\end{array}$ \\
\hline
\end{tabular}

Figura 6. Resultados do Grupo Focal 2 - Análise Global do Método

\begin{tabular}{|l|l|}
\hline Percepção do Fator "Organização do Trabalho" (Média: 6,41) \\
\hline Aspectos positivos percebidos & Aspectos negativos \\
\hline $\begin{array}{l}\text { Desburocratização do trabalho } \\
\text { Melhoria da organização do trabalho com o decorrer } \\
\text { das sprints }\end{array}$ & $\begin{array}{l}\text { Elevado nível de pressão e cobrança no início do projeto } \\
\text { (hora-extra, cancelamento de férias) }\end{array}$ \\
$\begin{array}{l}\text { Maior foco no produto } \\
\text { Melhoria dos problemas relacionados aos prazos } \\
\text { Opinião da equipe desconsiderada } \\
\text { Dúvidas e questionamentos em decorrência da defini- } \\
\text { ção do processo ágil e PSDS }\end{array}$ \\
$\begin{array}{l}\text { Melhoria na divisão de tarefas e no planejamento } \\
\text { Multidisciplinaridade } \\
\text { Participação de todos na organização do trabalho }\end{array}$
\end{tabular}$\quad$\begin{tabular}{l} 
Sucesso no planejamento e nas entregas \\
\hline
\end{tabular}

Figura 7. Resultados do Grupo Focal 2 - Análise da Organização do Trabalho

\begin{tabular}{|c|c|}
\hline \multicolumn{2}{|l|}{ Percepção do Fator "Condições de Trabalho" (Média: 5,93) } \\
\hline Aspectos positivos percebidos & Aspectos negativos percebidos \\
\hline $\begin{array}{l}\text { Validação do modelo de layout proposto (com muitas } \\
\text { ressalvas) } \\
\text { Manutenção das boas condições de trabalho }\end{array}$ & $\begin{array}{l}\text { Indisponibilidade de recursos para realização de } \\
\text { videoconferência } \\
\text { Necessidade de mais suporte logístico: quadro, área } \\
\text { para reunião e TV } \\
\text { Melhoria do suporte tecnológico para os ambientes de } \\
\text { desenvolvimento: ferramentas e softwares } \\
\text { - } \\
\text { Espaço reduzido para trabalhar e armazenar pertences } \\
\text { Redução do conforto e do isolamento acústico } \\
\text { Demora na instalação do novo ambiente físico } \\
\text { Ausência de melhorias no ambiente físico }\end{array}$ \\
\hline
\end{tabular}

Figura 8. Resultados do Grupo Focal 2 - Análise das Condições de Trabalho

\footnotetext{
${ }^{4}$ Membro do Time Ágil que, pelo seu conhecimento e facilidade de acesso aos recursos de infraestrutura, colabora no desenho da arquitetura da solução e atua no provimento de soluções de infraestrutura e na configuração de todos os ambientes do projeto, envolvendo especialistas das diversas unidades da empresa, sempre que necessário. 


\begin{tabular}{|l|l|l|}
\hline Percepção do Fator "Relações Socioprofissionais" (Média: 8,07) \\
\hline Aspectos positivos percebidos no fator & Aspectos negativos percebidos no fator \\
\hline $\begin{array}{l}\text { Melhoria da comunicação e da relação com outras } \\
\text { áreas, entre os membros do time, hierárquica e com o } \\
\text { cliente }\end{array}$ & $\begin{array}{l}\text { Comunicação com outras regionais deficitária } \\
\text { Preocupação com a forma de realização da avaliação de } \\
\text { desempenho } \\
\text { Facilidade na interação com outras áreas em } \\
\text { decorrência da condição de piloto } \\
\text { muitos membros na tomada de decisão pelas equipes com } \\
\text { Interferência da chefia imediata na tomada de decisão } \\
\text { pelo time } \\
\text { Alocação dos membros do time e Scrum Master em } \\
\text { projetos paralelos } \\
\text { Falta poder de decisão para a equipe atuar na } \\
\text { integração com outros sistemas }\end{array}$ \\
\hline
\end{tabular}

Figura 9. Resultados do Grupo Focal 2 - Análise das Relações Socioprofissionais

\begin{tabular}{|l|l|}
\hline \multicolumn{2}{|l|}{ Percepção do Fator "Práticas de Gestão" (Média: 8,06) } \\
\hline Aspectos positivos percebidos no fator & Aspectos negativos percebidos no fator \\
\hline$\quad$ Evolução na auto-organização da equipe & \\
$\quad$ Forte redução do estresse inicial & $\begin{array}{l}\text { Necessidade de desenvolvimento de novas } \\
\text { competências pelos membros do time (maturidade, } \\
\text { proatividade, comunicação, entre outros) }\end{array}$ \\
$\quad$ Boa organização e maturidade da equipe \\
$\quad$ Scrum Master é membro do time e não chefe funcional \\
Maior autonomia para a equipe
\end{tabular}$\quad$\begin{tabular}{l} 
Responsabilidades compartilhadas \\
\hline
\end{tabular}

Figura 10. Resultados do Grupo Focal 2 - Análise das Práticas de Gestão

\section{DISCUSSÃO}

O conjunto de instrumentos utilizados permitiu analisar a implantação do método ágil em momentos distintos, facilitando a compreensão da dinâmica de todo o processo e identificando/ caracterizando as percepções dos trabalhadores em cada fase da coleta.

Em relação à primeira etapa da coleta, antes da implantação do novo método, algumas questões são relevantes de serem discutidas. Globalmente, houve boa aceitação por parte dos empregados do processo de mudança, gerando altas expectativas em todos os projetos. Este é um cenário positivo à organização no processo, já que a resistência à mudança ainda é considerada uma das principais barreiras à transformação organizacional bemsucedida (Hernandez e Caldas, 2001).

Entre as expectativas positivas ressaltadas pelo grupo na primeira etapa, destaca-se a melhoria dos processos de trabalho, a melhor integração entre as áreas e equipes e a maior autonomia e responsabilidade, elementos relacionados à organização do trabalho. Por se tratarem de empregados da área da tecnologia da informação, que, por natureza, está em constante mudança, é possível que essa abertura ao novo seja um traço do grupo, o que não gerou grandes resistências ao processo, ainda que a resistência tenha sido apontada inicialmente entre as expectativas negativas. Em relação às expectativas negativas, 
destaca-se o receio da gestão inadequada no novo método de trabalho, o que remete novamente à organização do trabalho e também às práticas de gestão.

A segunda etapa de coleta, durante o processo de implantação do método ágil, evidenciou alguns aspectos relevantes. 0 termômetro da QVT, cuja coleta aconteceu diariamente por um período de 45 dias em média, mostrou que em três grupos predominou o sentimento de bem-estar com o trabalho, enquanto em outros três grupos a média foi menor, indicando sentimentos que oscilaram entre bem-estar e malestar. Ferreira (2012) ressalta que sentimentos de bem-estar e mal-estar oscilam em um continuum de representações, e que há a percepção de QVT quando existe um predomínio de representações positivas.

Os grupos focais e as observações permitiram aprofundar a investigação e identificar os principais problemas que os trabalhadores estavam encontrando para lidar com a nova metodologia de trabalho, além de mapear as estratégias de mediação individual e coletiva desenvolvidas para lidar com esses problemas e de levantar sugestões para evita-los. De novo, aspectos relacionados à organização do trabalho emergiram, como a sobrecarga de trabalho, a dificuldade em lidar com projetos e sistemas de controle paralelos e o excesso de reuniões. Os empregados relataram sentimentos de estresse, frustração, cansaço e desmotivação como consequência desses problemas.

Entre as sugestões dadas para evitar os problemas apresentados, destacam-se a necessidade de dar mais autonomia, de diminuir a carga de trabalho e de dividir melhor as tarefas. Ferreira (2012) aponta que pesquisas realizadas no âmbito do serviço público brasileiro evidenciaram que, no que concerne à autonomia, alguns "ingredientes" compõem a promoção da QVT, como o foco na valorização do uso da inteligência humana e o tratamento devido à capacidade dos trabalhadores de resolver de forma criativa os problemas no trabalho. Outros autores (Jorge, 2009; Maia, 2014; Morin, 2001) também apontam o a importância da autonomia como prática de valorização das competências dos trabalhadores.

O último grupo focal, realizado após o encerramento dos projetos piloto, mapeou as principais percepções sobre o que melhorou e o que piorou no trabalho dos grupos com a implantação do método. A média geral atribuída pelo grupo, de 7,22, demonstra que de modo geral os trabalhadores ficaram satisfeitos com o método ágil na organização. Nesse instrumento, mapeou-se também as percepções acerca dos fatores mais críticos do macrodiagnóstico (organização do trabalho, condições de trabalho, relações socioprofissionais e práticas de gestão). Nesse caso, as condições de trabalho e a organização do trabalho apresentaram a pior avaliação.

No quesito condições de trabalho, os empregados destacaram a ausência de recursos necessários à condução das atividades propostas no método e a demora na instalação do novo ambiente físico que havia sido prometido quando do início do projeto. Há algumas décadas estudos já evidenciam as condições de trabalho inadequadas como fonte de mal-estar no trabalho e demonstram os impactos negativos desse elemento na qualidade de vida no trabalho (Lawler, 1982; Santos, 2014; Tolfo, Silva e 


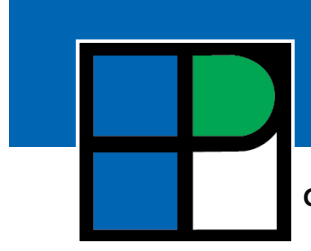

Grupo de Estudos Pesquisas em

Luna (2009); Zhao et al., 2012). Segundo os autores, promover boas condições de trabalho implica promover bem-estar físico e mental dos trabalhadores e, consequentemente, a QVT. Em uma organização cuja tecnologia está no centro dos trabalhos desenvolvidos e dos produtos entregues à sociedade, investir em condições de trabalho é, portanto, preponderante.

Quanto à organização do trabalho, houve relato de elevado nível de pressão e de cobrança, aumentando o estresse das equipes, cancelamento de férias e aumento de horas-extras. Essas representações são geradoras de mal-estar no trabalho e, portanto, potencializadoras de agravos à saúde física e mental dos trabalhadores.

Globalmente, os resultados evidenciaram que, embora o coletivo dos participantes tenha percebido de forma positiva o novo método de trabalho, questões relacionadas à organização do trabalho merecem ser cuidadas para que não possam impactar negativamente na qualidade de vida no trabalho. Estudos (Ahmad, 2013; Boisvert, 1980; Ferreira, 2012; Nogueira e Frota, 2011) apontam que a organização do trabalho é o principal fator promotor de QVT.

Um vasto conjunto de pesquisas realizadas no âmbito do setor público brasileiro vem demonstrando que a aspectos relacionados à organização do trabalho tem sido os principais responsáveis pelo mal-estar dos trabalhadores (Albuquerque, 2011; Ferreira, 2012; Maia, 2014; Santos, 2014). Nesse sentido, parece premente investir em formas de compreender o trabalho realizado nessas instituições para buscar estratégias que permitam transforma-lo em um trabalho que dê espaço à autonomia, que tenha coerência entre as características das tarefas, com regras e procedimentos que facilitem e não dificultem a execução da atividade, resultando em eficácia e em uma produtividade "saudável".

Tratando especificamente do contexto pesquisado, faz-se necessário uma reflexão sobre a reconversão tecnológica. Novos desafios surgem a cada nova aplicação no campo da interação homem-computador e homem-trabalho. Introduzir inovações tecnológicas nas organizações leva, necessariamente, ao desenvolvimento e adoção de uma nova organização do trabalho que permita compatibilizar os novos recursos com suas possibilidades de uso (Brusiquese e Ferreira, 2012; Howell, 1993; Olson e Olson, 2003). Nesse sentido, é imprescindível, ao implantar novas tecnologias, considerar o contexto no qual ocorre a mudança (Daniellou, 2004; Carayon, 1989; Grandjean, 1998; Santos, 2008; Wisner, 1992).

\section{CONCLUSÕES}

O presente estudo buscou mapear os principais impactos de um processo de reconversão tecnológica na qualidade de vida no trabalho de empregados de uma empresa pública brasileira. Questões relacionadas às condições de trabalho e à organização do trabalho estiveram no centro das representações dos trabalhadores, demonstrando um conjunto de elementos que devem ser cuidados em processos como o implantado na organização, com destaque ao excesso de ferramentas de controle, à pressão, à falta de autonomia e à falta de estrutura física para realização do trabalho. Ainda assim, globalmente o grupo demonstrou bem-estar com o novo método de trabalho. 
O vasto ferramental utilizado pode ser destacado como um diferencial da pesquisa. A realização do estudo em três momentos distintos permitiu acompanhar a percepção dos grupos sobre o processo de implantação do novo método de trabalho, identificando "gargalos" que podem ter obstaculizado as atividades.

Os resultados permitiram, portanto, confirmar a hipótese delineada, de que a percepção global dos trabalhadores acerca da implantação do método ágil é positiva, mas existem fatores relacionados à organização do trabalho que podem obstaculizar as atividades e impactar negativamente na qualidade de vida no trabalho.

Quanto às contribuições da pesquisa, podese destacar: a) os aportes fornecidos pelos trabalhadores para o aprimoramento da organização do trabalho no novo método; b) o reforço da aplicabilidade da EAA_QVT; c) a geração de subsídios à gestão organizacional focada na promoção de QVT; d) a proposição de um método que instrumentaliza a gestão para a ação.

Há que se destacar a posição de vanguarda da instituição, que ao implantar um novo processo

\section{REFERÊNCIAS}

Ahmad, S. (2013). Paradigms of quality of work life. Journal of Human Values, 19 (1), 73-82.

Albuquerque, V. P. (2011). Qualidade de Vida no Trabalho, BemEstar e Mal-Estar Sob a Ótica de Trabalhadores de Uma Agência Reguladora Brasileira. Dissertação de mestrado, Programa de Pós-Graduação em Psicologia Social, do Trabalho e das Organizações (PSTO), Universidade de Brasília, Brasília, DF, Brasil.

Boisvert, M. (1980). La qualité de la vie au travail: Regards sur l'expérience québécoise. Ottawa: Agence D’Arcy.

Bragard, I.; Dupuis, G.; Razavi, D.; Reynaert, C.; Etienne, A.M. (2012). Quality of work life in doctors working with cancer patients. Occupational Medicine, 62, 34-40. de trabalho, o fez de forma cuidadosa, iniciando a aplicação em pilotos antes de expandir o novo método a toda a organização. Merece destaque também a condução de forma participativa, buscando, com os protagonistas do processo produtivo, encontrar alternativas para as melhorias do novo método de trabalho. Em se tratando de serviço público brasileiro, cujas normas burocráticas enrijecem as mudanças, entende-se que a estratégia foi bastante inovadora e relevante.

Como futura agenda de pesquisa sugere-se a nova realização de diagnóstico, após a expansão do método a todas as unidades da empresa, para identificar outras dificuldades ou lacunas que podem comprometer a qualidade de vida no trabalho e os resultados organizacionais. Ademais, estudos comparativos com outras instituições que passaram pelo processo de implantação da metodologia ágil poderão contribuir para o avanço do conhecimento na temática. Por fim, sugere-se o desenvolvimento de estudos que investiguem os impactos de processos de reconversão tecnológica na saúde dos trabalhadores.

Brunault, P.; Fouquereau, E.; Colombat, P.; Gillet, N.; El-Hage, W.; Camus, V.; Gaillard, P. (2013). Do transactive memory and participative teamwork improve nurses' quality of work life? Western Journal of Nursing Research, 36 (3), 329-345.

Brusiquese, R. G.; Ferreira, M. C. (2012). Inovações tecnológicas e organizacionais em escritórios e os impactos na qualidade de vida no trabalho. Cadernos de Psicologia Social do Trabalho, 15 (1), 1-16.

Carayon, P.; Smith, M.J. (1989). Balance Theory of Job Design. International Journal of Industrial Ergonomics. 4, 67-79.

Cooper, D. R.; Schindler, P. S. (2003). Métodos de pesquisa em administração (7a ed.). São Paulo: Bookman. 
Daniellou, F. (2004). Questões epistemológicas levantadas pela ergonomia de projeto. In: Daniellou, F. (Coord.). A ergonomia em busca de seus princípios: debates epistemológicos. São Paulo: Edgard Blucher, p. 181-198.

Decca, E. S. (1988). O nascimento das fábricas: Vol. 51. Tudo é História. São Paulo, SP: Brasiliense.

De Toni, M. (2006). Fim do trabalho versus centralidade do trabalho. In: Cattani, A. D.; Holzmann, L. (orgs.). Dicionário: Trabalho e tecnologia. Porto Alegre, Editora da UFRGS, pp. 127-131.

Fagundes, P. B. (2005). Framework para comparação e análise de métodos ágeis. Programa de Pós-Graduação em Ciência da Computação, Universidade Federal de Santa Catarina, Florianópolis, SC, Brasil.

Ferreira, M.C. (2012). Qualidade de Vida no Trabalho. Uma Abordagem Centrada no Olhar dos Trabalhadores. $2^{\text {a }}$ edição. Paralelo 15.

\section{Gil, A. C.; (2009). Estudo de Caso. São Paulo: Atlas.}

Grandjean, E. (1998). Prefácio. In Manual de ergonomia: adaptando o trabalho ao homem. Porto Alegre: Artmed.

Guérin, F., Laville, A., Daniellou, F., Duraffourg, J. ; Kerguelen, A. (2001). Compreender o Trabalho para Transformá-lo: $A$ prática da ergonomia. São Paulo: Blucher, Fundação Vanzolini.

Günther, H. (2006). Pesquisa qualitativa versus pés quisa quantitativa: esta é a questão? Psicologia: Teoria e Pesquisa, 22(2), 201-210.

Gressler, L. A. (2004). Introdução à pesquisa: projetos e relatórios. $2^{\mathrm{a}}$ Ed. São Paulo: Loyola.

Hackman, J. R.; Oldham, G. R. (1974). The job diagnostic survey: an instrument for the diagnosis of jobs and the evaluation of job redesign projects. Technical Report: 4, Department of Administrative Sciences of Yale University.

Hernandez, J.M.C; Caldas, M.P. (2001). Resistência à mudança: uma revisão crítica. Revista de Administração de Empresas (RAE), 41(2), 31-45.

Howell, W. C. (1993). Engineering psychology in a changing world. Annual Reviews: Psychology, 44, 231-263.

Jorge, S. M. (2009). A qualidade de vida no trabalho: Um estudo junto aos servidores públicos da Subseção Judiciária Federal de Campinas/SP. (Dissertação de Mestrado, Universidade Metodista de Piracicaba, Brasil).
Josiah, R. A.; Odera, 0.; Chepkuto, P.; Okaka, O. (2012). Effects of quality of work life on job performance: theoretical perspectives and literature review. Current Research Journal of Social Science, 4 (5), 383-388.

Lacaz, F. A. C. (2000). Qualidade de vida no trabalho e saúde/ doença. Ciência \& Saúde Coletiva, 5(1), 151-161.

Landim, F. L. P., Lourinho, L. A., Lira, R. C. M.; Santos, Z. M. S. A. (2006). Uma reflexão sobre as abordagens em pesquisa com ênfase na integração qualitativoquantitativa. Revista Brasileira em Promoção da Saúde, 19(1), 53-58.

Lawler, E. E. (1982). Strategies for improving the quality of work life. American Psychologist, 37 (5), 486-493.

Leite, M.P. (1994). Reestruturação produtiva, novas tecnologias e novas formas de gestão da mão de obra. In: Oliveira, B.C.A. (org). 0 mundo do trabalho. Crises e mudanças no final do século. São Paulo: Scritta.

Maia, M.C. (2014). Tribunal da cidadania?! Pra quem?! Qualidade de Vida no Trabalho em um órgão do poder judiciário brasileiro. Dissertação de mestrado, Programa de Pós-Graduação em Psicologia Social, do Trabalho e das Organizações (PSTO), Universidade de Brasília, Brasília, DF, Brasil.

Marx, K. (1989). Trabalho alienado e superação positiva da autoalienação humana. In F. Fernandes (Ed.), Marx/Engels: Vol. 36. Grandes Cientistas Sociais. História (pp. 146-181). São Paulo: Ática.

Melo, C. 0.; Ferreira, G. R. M. (2010). Adoção de métodos ágeis em uma Instituição Pública de grande porte - um estudo de caso. In: Workshop Brasileiro de Métodos Ágeis (WBMA), 2010, Porto Alegre. Conferência Brasileira sobre Métodos Ágeis de Desenvolvimento de Software (Agile Brazil 2010), 2010. v. 1. p. 104-117.

Morin, E. M. (2001). Os sentidos do trabalho. Revista de Administração de Empresas (RAE), 41 (3), 9-19.

Nadler, D. A.; Lawler, E. E. (1983). Quality of work life: perspectives and directions. Organizational Dynamics: 11 (3), 20-30.

Navarro, V.L.; Padilha, V. (2007). Dilemas do trabalho no capitalismo contemporâneo. Psicologia e Sociedade: 19 ( $\mathrm{n}^{\circ}$ esp), 14-20.

Nayeri, N. D.; Salehi, T.; Noghabi, A.A.A. (2011). Quality of work life and productivity among Iranian nurses. Contemporary Nurse, 39 (1), 106-118. 
Nogueira, C. V. \& Frota, F. H. S. (2011). Qualidade de vida no trabalho: Percepções sobre sua importância como Política de Valorização no Serviço Público. Revista do Mestrado Profissional em Planejamento em Políticas Públicas, 31-58.

Olson, G. M.; Olson, J. S. (2003). Human-computer interaction: psychological aspects of the human use of computing. Annual Reviews: Psychology, 54, 491-516.

Ouriveis, M. (2013). Acumulação flexível, tecnologia e mudanças no mundo do trabalho: da reestruturação produtiva aos home offices. Estudos do Trabalho: 12, 1-23.

Ranieri, J. (2001). A câmara escura: Alienação e estranhamento em Marx. São Paulo, SP: Boitempo.

Rebecchi, E. (1990). O sujeito frente à inovação tecnológica. Petrópolis: Vozes.

Rodrigues, M. V. C. (2011). Qualidade de Vida no Trabalho: evolução e análise no nível gerencial. $13^{\mathrm{a}}$ ed. São Paulo: Ed. Vozes.

Sampaio, J. R. (2012). Qualidade de vida no trabalho: perspectivas e desafios atuais. Revista Psicologia Organizacional e Trabalho, 12 (1), 121-136.

Santos, L.A. (2014). "Quando chega domingo, fico triste de ter que trabalhar na segunda": a qualidade de vida no trabalho em questão no serviço público federal. Tese de doutorado, Programa de Pós-Graduação em Psicologia Social, do Trabalho e das Organizações (PSTO),
Universidade de Brasília, Brasília, DF, Brasil.

Santos, M.S. (2008). Ergonomia de concepção na prevenção de inadequações no ambiente de trabalho construído. Ação Ergonômica, 3(2), 16-24.

Tolfo, S. R.; Silva, N.; Luna, I. N. (2009). Cultura organizacional, identidade e qualidade de vida no trabalho: articulações e sugestões de pesquisas em organizações. Pesquisas e práticas psicossociais, 4 (1), 6-16.

Walton, R. E. (1973). Quality of working life: what is it? Slow Management Review. 15 (1), 11-2.

Werther, B. W; Davis, K. (1983). Administração de pessoal e recursos humanos: a qualidade de vida no trabalho. São Paulo: Mcgraw-Hill do Brasil.

Westley, W. A. (1979). Problems and solutions in the quality of working life. Humans Relations: 32 (2), 111-123.

Wisner, A. (2004). Questões epistemológicas em ergonomia e em análise do trabalho. Em F. Daniellou (Org.), $A$ Ergonomia em busca de seus princípios: Debates epistemológicos (pp. 29-56). São Paulo: Edgard Blücher.

Wisner, A. (1992). A antropotecnologia. Estudos Avançados: 6 (16), 29-34.

Van de Ven, A. H. (1986). Central problems in the management of innovation. Management Science, 32 (5), 590-607. 


\section{CONCLUSÃO}

Os achados encontrados na presente pesquisa permitiram conhecer, em dois níveis analíticos (macrodiagnóstico e microdiagnóstico), a avaliação de trabalhadores de uma empresa pública brasileira acerca da qualidade de vida no trabalho. Possibilitaram mapear também os impactos de um processo de reconversão tecnológica na percepção de QVT de um grupo de empregados da instituição.

Os resultados do macrodiagnóstico indicaram, na escala que avalia o contexto de trabalho, que os elementos que compõem os fatores "Organização do Trabalho" e "Reconhecimento e Crescimento Profissional" são os mais críticos na percepção dos trabalhadores da instituição. Identificou-se ainda que a percepção sobre as "Práticas de Gestão" encontrase em zona de transição, apontando que estas devem ser elemento de atenção para a promoção de QVT. Por fim, a escala que mapeia desgastes e sentimentos positivos e negativos em relação ao trabalho evidenciaram que globalmente há percepção de bem-estar moderado.

Ainda no nível macro de análise, identificouse as principais fontes de bem-estar e mal-estar no trabalho dos empregados da instituição. Os núcleos temáticos que compõem as fontes de bem-estar no trabalho são: "Organização Burocrática do Trabalho"; "Condições de Trabalho Inadequadas e Deslocamento Desgastante"; "Relacionamentos Conflituosos e Tratamento Desigual"; "Desvalorização do Mérito Técnico"; "Falta de Valorização e Reconhecimento pela Sociedade"; "Injustiça e Iniquidade"; e "Falta de Perspectiva de Crescimento Profissional". Por sua vez, as principais fontes de bem-estar no trabalho identificadas foram:
"Importância e significado do trabalho"; "Relações de trabalho harmoniosas"; "Relevância social do trabalho e oportunidade de desenvolver competências"; "Estabilidade e benefícios"; "Fazer o que gosta"; e "Condições de trabalho confortáveis".

No segundo nível analítico, realizou-se o acompanhamento de um processo de implantação de um novo método de trabalho, sendo mapeadas as expectativas dos trabalhadores acerca do processo de mudança, bem como as percepções de QVT durante e após a implantação. Globalmente, observou-se que o grupo percebeu positivamente a nova abordagem. Foi possível identificar as estratégias de mediação que os mesmos desenvolveram durante todo o processo para lidar com as dificuldades que surgiram, além de observar in loco a atividade dos grupos durante a implementação do método.

Os resultados indicam que, embora aparentemente o "Método Ágil" pareça ser pertinente, o que foi externalizado em momentos diversos durante a coleta de dados, há aspectos essenciais, especialmente da organização do trabalho e das práticas de gestão, que precisam ser melhorados para que o trabalho resulte em bemestar dos indivíduos e em eficácia organizacional. Um exemplo disso é a necessidade apontada pelos trabalhadores de rever a divisão das tarefas e de desenvolver nos grupos a capacidade de autogestão, dando mais autonomia às equipes.

Entendendo que a QVT se materializa/ expressa por meio de representações e sentimentos que os trabalhadores fazem de seu contexto de trabalho, moderados por práticas de gestão que devem primar pela promoção de bem-estar no 


\section{CONCLUSÃO}

trabalho e tendo como base a literatura pesquisada, as experiências da autora em estudos e intervenções no âmbito da EAA_QVT e as reflexões resultantes dos debates do grupo de pesquisa ErgoPublic, a presente pesquisa permitiu sustentar, portanto, a seguinte tese:

As características do contexto de trabalho, em especial, da organização do trabalho e das práticas de reconhecimento e crescimento profissional, associadas às práticas de gestão e aos sentimentos dos trabalhadores em relação ao trabalho configuram um perfil complexo de Custo Humano do Trabalho (físico, cognitivo e afetivo) que obstaculiza a construção de estratégias operatórias de mediação individual e coletiva para a operacionalização das prescrições do trabalho e potencializa vivências de mal -estar no trabalho colocando em risco a qualidade de vida no trabalho desses trabalhadores.

Como limite desta pesquisa destaca-se o pouco tempo disponibilizado para a realização das observações simples e sistemáticas no nível microanalítico. Essa contingência restringiu a descrição e análise mais profunda da atividade de trabalho no "Método Ágil".

As principais contribuições, já apresentadas nos artigos que compõem este documento, referem-se: a) à possibilidade de enriquecimento da EAA_QVT (e.g. compreensão de como se relacionam as variáveis apresentadas no modelo teórico-descritivo e a aplicação do inventário em uma empresa pública, contexto em que ainda não havia sido aplicada a abordagem); b) à chance de propiciar aportes (e.g. diagnóstico da percepção dos trabalhadores dos fatores estruturantes de QVT) à organização para a construção e condução de uma política de QVT efetiva, centrada na participação daqueles que devem ser os protagonistas das organizações: os trabalhadores; e c) à perspectiva de promoção da cidadania organizacional e para os usuários dos serviços públicos.

Sugere-se, como agenda de pesquisa de estudos futuros, uma nova aplicação do IA_QVT para a realização de estudo longitudinal, na perspectiva de mapear as percepções dos empregados após a implantação da política de QVT, bem como de avaliar a efetividade das práticas utilizadas. Também, como agenda, há a possibilidade de realização de estudos comparativos, no âmbito da abordagem, entre poderes e/ou esferas distintas. Por fim, a realização de diagnósticos em EAA_QVT em contextos privados poderão contribuir para compreender as diferenças das políticas de QVT em contextos díspares.

À guisa de conclusão, cabe reforçar que a presente pesquisa, conforme já descrito, caracterizada como estudo de caso, encontra-se filiada epistemologicamente à Ergonomia da Atividade. Nessa perspectiva, ao compreender cada contexto como único, composto por trabalhadores únicos, não há a pretensão de generalização de resultados.

Finalmente, resgata-se a afirmação de renomado ergonomista de que" (...) não há limite nos conhecimentos das disciplinas, que podem ser recrutados para a interpretação de uma atividade de trabalho" (Daniellou, 2004, p. 187). Nesse sentido, espera-se que as muitas áreas e subáreas das ciências humanas, sociais, da saúde e do trabalho possam de fato contribuir, cada uma em seu campo de atuação, para a compreensão do trabalho na perspectiva de transforma-lo em prol do bem-estar e da felicidade do trabalhador. 


\section{ErgoPublic}

\section{REFERÊNCIAS GERAIS}

Abarqhouei, N. S.; Nasab, H. H. (2011). Total ergonomics and its impact in musculoskeletal disorders and quality of work life and productivity. Open Journal of Safety Science and Technology, 1, 79-88.

Ahmad, S. (2013). Paradigms of quality of work life. Journal of Human Values, 19 (1), 73-82.

Aketch, J. R.; Odera, 0.; Chepkuto, P.; Okaka, 0. (2012). Effects of quality of work life on job performance: theorical perspectives. Research Journal of Social Science , 4(5), 383388.

Albuquerque, V. P. (2011). Qualidade de Vida no Trabalho, BemEstar e Mal-Estar Sob a Ótica de Trabalhadores de Uma Agência Reguladora Brasileira. Dissertação de mestrado, Programa de Pó s-Graduação em Psicologia Social, do Trabalho e das Organizações (PSTO), Universidade de Brasília, Brasília, DF, Brasil.

Alves, W. F. (2010). Qualidade de vida no trabalho: indicadores e instrumentos de medidas. Diálogos e Saberes, 6 (1), 77 87.

Amalberti, R.; Montmollin, M.; Theureau, J. (Orgs.). (1991). Modèles en analyse du travail. Liège: Mardaga.

An, J. Y.; Yom, Y. H.; Ruggiero, J. S. (2011). Organizational culture, quality of work life, and organizational effectiveness in Korean University. Journal of Transcultural Nursing, 22(1), 22-30.

Andrade, P. P. (2011). Sentimento de (in) justiça na Justiça: fatores (des) estruturantes de QVT sob a ótica dos servidores de um órgão do poder judiciário. Dissertação de mestrado, Programa de Pós-Graduação em Psicologia Social, do Trabalho e das Organizações (PSTO), Universidade de Brasília, Brasília, DF, Brasil.

Antloga, C.S.; Avelar, R. (2013). Mal-estar no trabalho. In: Vieira, Mendes e Merlo (orgs.). Dicionário Crítico de Gestão e Psicodinâmica do Trabalho. São Paulo: Juruá Editora.

Antloga, C.S.; Pinheiro, I; Maia, M. M.; Lima, H. K. B. (2014). Mal-estar no trabalho: representações de trabalhadores de um órgão público de pesquisa. Revista Subjetividades, 14 (1), 126-140.

Antunes, R. (1999). Os sentidos do trabalho: Ensaios sobre a afirmação e a negação do trabalho. São Paulo, SP: Boitempo.
Antunes, R. (2008). As formas de padecimento no trabalho. Saúde e sociedade, 17(1), 7-8.

Araújo, J.N.G. (2010). Qualidade de vida no trabalho: controle e escondimento do mal-estar do trabalhador. Trab. Educ. Saúde, 7 (3), 573-585.

Araújo, T. M., Sena, I. P., Viana, M. A., Araújo, E. M. (2006). Mal -estar docente: Avaliação de condições de trabalho e saúde em uma instituição de ensino superior. Revista Baiana de Saúde Pública, 29(1), 6-21.

Aznar, M. P. M., Rodriguez, M. A. G.; Aznar, M. J. M. (2006). Estrés y malestar en el profesorado. International Journal of Psychology and Psychological Therapy, 6(1), 63-76.

Barros, A.R.O. (2007). Comprometimento organizacional: um estudo de suas relações com práticas de gestão de pessoas e intenção de permanência. Dissertação de mestrado, Programa de Pós-Graduação em Administração, Universidade Federal da Bahia, Salvador, BA, Brasil.

Bauman, Z. (1998). 0 mal-estar da pós-modernidade. Rio de Janeiro, RJ: Jorge Zahar.

Bendassolli, P. (2011). Mal-estar no trabalho: Do sofrimento ao poder de agir. Revista Mal-estar e Subjetividade, 10(1), 6398.

Boisvert, M. (1980). La qualité de la vie au travail: Regards sur l'expérience québécoise. Ottawa: Agence D'Arcy.

Bragard, I.; Dupuis, G.; Razavi, D.; Reynaert, C.; Etienne, A.M. (2012). Quality of work life in doctors working with cancer patients. Occupational Medicine, 62, 34-40.

Branquinho, N. G. S. (2010). Qualidade de Vida no Trabalho e vivências de bem-estar e mal-estar no trabalho em professores da rede pública de ensino de Unaí/MG. Dissertação de Mestrado, Programa de Pós-Graduação em Psicologia Social, do Trabalho e das Organizações (PSTO), Universidade de Brasília, Brasília, DF, Brasil.

Brasil (2012). Resolução No 196/96. Recuperado de http:// conselho.saude.gov.br/web_comissoes/conep/arquivos/ resolucoes/23_out_versao_final_196_ENCEP2012.pdf.

Brunault, P.; Fouquereau, E.; Colombat, P.; Gillet, N.; El-Hage, W.; Camus, V.; Gaillard, P. (2013). Do transactive memory and participative teamwork improve nurses' quality of work life? Western Journal of Nursing Research, 36 (3), 329-345. 


\section{REFERÊNCIAS GERAIS}

Brusch, V. L. A.; Monteiro, J.K. (2011). Relações entre colegas como manifestações de resistência ao adoecimento no trabalho. In: J.N.G. de Araújo, C.P.de Almeida, M. C. Ferreira e A. M. Mendes (Orgs.). Dominação e resistência no contexto trabalho-saúde (pp 121-140). São Paulo: Mackenzie.

Brusiquese, R. G.; Ferreira, M. C. (2012). Inovações tecnológicas e organizacionais em escritórios e os impactos na qualidade de vida no trabalho. Cadernos de Psicologia Social do Trabalho, 15 (1), 1-16.

Carayon, P.; Smith, M.J. (1989). Balance Theory of Job Design. International Journal of Industrial Ergonomics. 4, 67-79.

Castel, R. (2003). As metamorfoses da questão social: uma crônica ao salário. Petrópolis: Vozes.

Cervo, A. L.; Bervian, P. A.; Da Silva, R. (2007). Metodologia científica. $6^{a}$ ed. São Paulo: Pearson Prentice Hall.

Chávez, R. C. (2009). Condiciones de trabajo y bienestar/ malestar docente em profesores de enseñanza media de Santiago de Chile. Educação e Sociedade, 30(107), 409426.

Cooper, D. R., \& Schindler, P. S. (2003). Métodos de pesquisa em administração (7ª ed.). São Paulo: Bookman.

Costa, S. H. B. (2011). Carnaval: Trabalho ou diversão? Atividade, gestão e bem-estar nas escolas de samba do Rio de Janeiro. Tese de Doutorado, Programa de PósGraduação em Psicologia Social, do Trabalho e das Organizações (PSTO), Universidade de Brasília, DF, Brasil.

Dal Rosso, S. (2008). Mais trabalho! A intensificação do labor na sociedade contemporânea. São Paulo: Boitempo.

Daniel, J. B. (2012). "É-feito de coisas burocráticas": Impactos da organização do trabalho na qualidade de vida no trabalho em um órgão público federal. Dissertação de mestrado, Programa de Pós-Graduação em Psicologia Social, do Trabalho e das Organizações (PSTO), Universidade de Brasília, Brasília, DF, Brasil.

Daniellou, F. (2004). Questões epistemológicas levantadas pela ergonomia de projeto. In: Daniellou, F. (Coord.). A ergonomia em busca de seus princípios: debates epistemológicos. São Paulo: Edgard Blucher, p. 181-198.

De Toni, M. (2006). Fim do trabalho versus centralidade do trabalho. In: Cattani, A. D.; Holzmann, L. (orgs.). Dicionário: Trabalho e tecnologia. Porto Alegre, Editora da UFRGS, pp. 127-131.

Decca, E. S. (1988). O nascimento das fábricas: Vol. 51. Tudo é História. São Paulo, SP: Brasiliense.
Demo, P. (2011). Introdução à Metodologia da Ciência. $2^{\mathrm{a}}$ ed. São Paulo: Atlas.

Direnzo, M.S.; Greenhaus, J.H. (2011). Job search and voluntary turnover in a boundaryless world: a control theory perspective. Academy of Management Review, 36(3), 567589.

Dupuis G; Perrault J; Lambany M; Kennedy E; David P. (1989). A new tool to assess quality of life: the quality of life systemic inventory. Qual Life Cardiovasc Care, 5, 36-45.

Esteves, M. T. F. P. (2008). Práticas de gestão de recursos humanos e atitudes e comportamentos no trabalho: estudo de caso no sector bancário português. Tese de doutorado, Programa de Psicologia Social e das Organizações, Instituto Superior de Ciências do Trabalho e da Empresa (ISCTE), Portugal.

Fagundes, P. B. (2005). Framework para comparação e análise de métodos ágeis. Programa de Pós-Graduação em Ciência da Computação, Universidade Federal de Santa Catarina, Florianópolis, SC, Brasil.

Feitosa, L. R. C. (2010). E se a orquestra desafinar? Contexto de produção e qualidade de vida no trabalho dos músicos da Orquestra Sinfônica de Teresina/PI. Dissertação de Mestrado, Programa de Pós-Graduação em Psicologia Social, do Trabalho e das Organizações (PSTO), Universidade de Brasília, Brasília, Brasil.

Fernandes, E. (1996). Qualidade de Vida no Trabalho: como medir para melhorar. Salvador: Casa da Qualidade.

Fernandes, L. C. (2013) "Estamos o tempo todo enxugando gelo": Qualidade de vida no trabalho e vivências de bemestar e mal-estar em um órgão do poder judiciário. Dissertação de mestrado, Programa de Pós-Graduação em Psicologia Social, do Trabalho e das Organizações (PSTO), Universidade de Brasília, Brasília, DF, Brasil.

Fernandes, L.C.; Ferreira, M.C. (2015). Qualidade de vida no trabalho e risco de adoecimento: estudo no poder judiciário brasileiro. Psicologia USP, 26(2), 296-306.

Fernandes, S.R.P.; Vasques-Menezes, I. (2012). Organização do trabalho: implicações para a saúde do trabalhador. In M. C. Ferreira \& H. Mendonça (Orgs.). Saúde e bem-estar no trabalho: dimensões individuais e culturais (pp. 261-275). São Paulo: Casa do Psicólogo.

Ferreira, M. C. (2008a). A Ergonomia da atividade se interessa pela qualidade de vida no trabalho? Reflexões empíricas e teóricas. Cadernos de Psicologia Social e do Trabalho, 11, 83-99. 


\section{REFERÊNCIAS GERAIS}

Ferreira, M.C. (2008b). 0 que pensam os trabalhadores franceses sobre as novas exigências do trabalho? In: Dal Rosso, S. \& Fortes, J. A. A. S. (Orgs.). Condições de trabalho no limiar do século XXI (pp. 173-188). Brasília: Épocca.

Ferreira, M. C. (2011). Custo Humano do Trabalho. In A. D. Cattani \& L. Holzmann (orgs.), Dicionário Trabalho e Tecnologia, 2a. Edição, Porto Alegre: Editora Zouk, pp. 97100.

Ferreira, M. C., Alves, L. \& Tostes, N. (2009). Gestão de qualidade de vida no trabalho (QVT) no serviço público federal: o descompasso entre problemas e práticas gerenciais. Psicologia: Teoria e Pesquisa, 25, 319-327.

Ferreira, M. C.; Mendes, A. M. (2003). Trabalho e riscos de adoecimento: $O$ caso dos auditores-fiscais da Previdência Social Brasileira. Brasília: Edições Ler, Pensar, Agir (LPA).

Ferreira, M. C.; Seidl, J. (2009). Mal-estar no trabalho: análise da cultura Organizacional de um contexto bancário brasileiro. Revista Psicologia: Teoria e Pesquisa, 25(2), 245-254.

Ferreira, M.C. (2012). Qualidade de Vida no Trabalho. Uma Abordagem Centrada no Olhar dos Trabalhadores. $2^{\text {a }}$ edição. Paralelo 15.

Ferreira, M.C.; Paschoal, T.; Ferreira, R.R. (2013). Qualidade de Vida no Trabalho: Política e Programa para uma empresa de tecnologia da informação. Relatório Técnico. Brasília DF.

Figueira, T.G. (2014). Bem-Estar, Mal-Estar e Qualidade de Vida no Trabalho em uma Instituição Pública Brasileira. Tese de Doutorado, Programa de Pós-Graduação em Psicologia Social, do Trabalho e das Organizações (PSTO), Universidade de Brasília, Brasília, DF, Brasil.

García, M., y Llorens, S. (2003). ¿Influyen los obstáculos laborales en el malestar docente? Fòrum de Recerca, 8. Servei de Publicacions. Universitat Jaume I.

Gil, A. C.; (2009). Estudo de Caso. São Paulo: Atlas.

Gisin, L.; Schulze, H.; Degenhardt, B. (2016). Boundary management as a crucial sucesso factor for flexible-mobile work, demonstrated in the case of home office. In: Deml et al. (orgs). Advances in ergonomic design of systems, products and processes. Springer.

Gomide, S. J.; Silvestrin, L.H.B.; Oliveira, A.F. (2015). Bem-estar no trabalho: o impacto das satisfações com os suportes organizacionais e o papel mediador da resiliência no trabalho. Psicologia: Organizações e Trabalho, 15(1), 1929.

Grandjean, E. (1998). Prefácio. In Manual de ergonomia: adaptando o trabalho ao homem. Porto Alegre: Artmed.
Green, F. (2004). Work intensification, discretion and the decline in well-being at work. Easter Economic Journal, 30(4), 615626.

Gressler, L. A. (2004). Introdução à pesquisa: projetos e relatórios. $2^{a}$ Ed. São Paulo: Loyola.

Guérin, F., Laville, A., Daniellou, F., Duraffourg, J. \& Kerguelen, A. (2001). Compreender o Trabalho para Transformá-lo: A prática da ergonomia. São Paulo: Blucher, Fundação Vanzolini.

Günther, H. (2006). Pesquisa qualitativa versus pesquisa quantitativa: esta é a questão? Psicologia: Teoria e Pesquisa, 22(2), 201-210.

Hackman, J. R.; Oldham, G. R. (1974). The job diagnostic survey: an instrument for the diagnosis of jobs and the evaluation of job redesign projects. Technical Report: 4, Department of Administrative Sciences of Yale University.

Hackman, J. R.; Oldham, G. R. (1975). Development of the Job Diagnostic Survey. Journal of Applied Psychology, 60 (2), 159-170.

Hernandez, J.M.C; Caldas, M.P. (2001). Resistência à mudança: uma revisão crítica. Revista de Administração de Empresas (RAE), 41(2), 31-45.

Howell, W. C. (1993). Engineering psychology in a changing world. Annual Reviews: Psychology, 44, 231-263.

Huang, T.C.; Lawler, J.; Lei, C.Y. (2007). The effects of quality of work life on commitment and turnover intention. Social Behavior and Personality, 35 (6), 735-750.

Jorge, S. M. (2009). A qualidade de vida no trabalho: Um estudo junto aos servidores públicos da Subseção Judiciária Federal de Campinas/SP. (Dissertação de Mestrado, Universidade Metodista de Piracicaba, Brasil).

Josiah, R. A.; Odera, 0.; Chepkuto, P.; Okaka, 0. (2012). Effects of quality of work life on job performance: theoretical perspectives and literature review. Current Research Journal of Social Science, 4 (5), 383-388.

Kanan, L. A.; Arruda, M. P. (2013). A organização do trabalho na era digital. Estudos de Psicologia (Campinas), 30 (4), 583591.

Koonmeee, K.; Singhapakdi, A.; Virakul, B.; Lee, D. J. (2010). Ethics institutionalization, quality of work life, and employee job-related outcomes: a survey of human resource managers in Thailand. Journal of Business Research, 63, 20-26.

Lacaz, F. A. C. (2000). Qualidade de vida no trabalho e saúde/ doença. Ciência \& Saúde Coletiva, 5(1), 151-161. 


\section{REFERÊNCIAS GERAIS}

Lacombe, B. M. B; Chu, R. A. (2008). Políticas e práticas de gestão de pessoas: as abordagens estratégicas e institucional. $R A E, 48$ (1), 25-35.

Landim, F. L. P., Lourinho, L. A., Lira, R. C. M.; Santos, Z. M. S. A. (2006). Uma reflexão sobre as abordagens em pesquisa com ênfase na integração qualitativoquantitativa. Revista Brasileira em Promoção da Saúde, 19(1), 53-58.

Lawler, E. E. (1982). Strategies for improving the quality of work life. American Psychologist, 37 (5), 486-493.

Lee, Y.W.; Dai, Y.T.; Park, C.G.; McCreary, L.L. (2013). Predicting quality of work life on nurses' intention to leave. Journal of Nursing Scholarship, 45 (2), 160-168.

Leite, J. V.; Ferreira, M. C.; Mendes, A. M. (2009). Mudando a gestão da qualidade de vida no trabalho. Psicologia: Organizações e Trabalho, 9(2), 109-123.

Leite, M.P. (1994). Reestruturação produtiva, novas tecnologias e novas formas de gestão da mão de obra. In: Oliveira, B.C.A. (org). 0 mundo do trabalho. Crises e mudanças no final do século. São Paulo: Scritta.

Li, J.; Yeo, R. K. (2011). Quality of work life and career development: perceptions of part-time MBA students. Employee Relations, 33 (3), 201-220.

Limongi-França, A. C. (2004). Qualidade de vida no trabalho QVT: conceitos e práticas nas empresas da sociedade pósindustrial. São Paulo: Atlas.

Limongi-França, A. C. (2013). 0 que é qualidade de vida no trabalho? Breve percurso conceitual, histórico e projeções para a próxima década. In: Ferreira, M. C.; Antloga, C. S. X.; Paschoal, T.; Ferreira, R. R. (orgs). (2013). Qualidade de Vida no Trabalho: questões fundamentais e perspectivas de análise e intervenção. Brasília: Paralelo 15.

Maciel, R. H., Sena, F. C.; Saboia, I. B. (2006). 0 mal-estar nas novas formas de trabalho: um estudo sobre a percepção do papel dos cooperados em uma cooperativa de trabalho autogestionário. Revista Mal-Estar e Subjetividade, 6(2), 535-560.

Maia, M.C. (2014). Tribunal da cidadania?! Pra quem?! Qualidade de Vida no Trabalho em um órgão do poder judiciário brasileiro. Dissertação de mestrado, Programa de Pós-Graduação em Psicologia Social, do Trabalho e das Organizações (PSTO), Universidade de Brasília, Brasília, DF, Brasil.

Marta, J. K. M.; Singhapakdi, A.; Lee, D. J.; Sirgy, M. J. (2013). Journal of Business Research, 66, 381-389.
Martel, J. P.; Dupuis, G. (2006). Quality of work life: theoretical and methodological problems, and presentation of a new model and measuring instrument. Social Indicators Research, 77, 333-368.

Martins, M.I.C.; Molinaro, A. (2013). Reestruturação produtiva e seu impacto nas relações de trabalho nos serviços públicos de saúde no Brasil. Ciência e Saúde Coletiva, 18(6), 16671676.

Marx, K. (1989). Trabalho alienado e superação positiva da autoalienação humana. In F. Fernandes (Ed.), Marx/Engels: Vol. 36. Grandes Cientistas Sociais. História (pp. 146-181). São Paulo: Ática.

Medeiros, L. (2012). "Somos a cara da prefeitura? Então somos a cara abandonada": ergonomia da atividade aplicada à qualidade de vida no trabalho no contexto do serviço público municipal. Tese de Doutorado, Programa de PósGraduação em Psicologia Social, do Trabalho e das Organizações (PSTO), Universidade de Brasília, Brasília, DF, Brasil.

Medeiros, L. F. R. \& Ferreira, M. C. (2011). Qualidade de vida no trabalho: uma revisão da produção científica de 19952009. Gestão Contemporânea, Porto Alegre, 8( 9), 9-34.

Melo, C. O.; Ferreira, G. R. M. (2010). Adoção de métodos ágeis em uma Instituição Pública de grande porte - um estudo de caso. In: Workshop Brasileiro de Métodos Ágeis (WBMA), 2010, Porto Alegre. Conferência Brasileira sobre Métodos Ágeis de Desenvolvimento de Software (Agile Brazil 2010), 2010. v. 1. p. 104-117.

Mendes, A. M.; Morrone, C. F. (2002). Vivências de prazer, sofrimento e saúde psíquica no trabalho: trajetória conceitual e empírica. Em: A. M. Mendes, L. O. Borges e M. C. Ferreira (Orgs.). Trabalho em transição, saúde em risco (pp. 42-57), Brasília: UnB.

Mendes, A.M.; Costa, V.P.; Barros, P.C.R. (2003). Estratégias de enfrentamento do sofrimento psíquico no trabalho bancário. Estudos e Pesquisas em Psicologia, 3(1), 1-11.

Morin, E. M. (2001). Os sentidos do trabalho. Revista de Administração de Empresas (RAE), 41 (3), 9-19.

Morin, E.; Tonelli, M.J.; Pliopas, A.L.V. (2007). 0 trabalho e seus sentidos. Psicologia e Sociedade, 19(1), 47-56.

Nadler, D. A.; Lawler, E. E. (1983). Quality of work life: perspectives and directions. Organizational Dinamics, 11 (3), 20-30.

Navarro, V.L.; Padilha, V. (2007). Dilemas do trabalho no capitalismo contemporâneo. Psicologia e Sociedade: 19 ( $\mathrm{n}^{\circ}$ esp), 14-20. 


\section{REFERÊNCIAS GERAIS}

Nayeri, N. D.; Salehi, T.; Noghabi, A.A.A. (2011). Quality of work life and productivity among Iranian nurses. Contemporary Nurse, 39 (1), 106-118.

Nogueira, C. V. \& Frota, F. H. S. (2011). Qualidade de vida no trabalho: Percepções sobre sua importância como Política de Valorização no Serviço Público. Revista do Mestrado Profissional em Planejamento em Políticas Públicas, 31-58.

Oliveira, G.S. (2010). Superexploração e mal-estar no trabalho no corte da cana-de-açúcar no Pontal do Paranapanema SP. Revista Pegada, 11(2), 77-94.

Olson, G. M.; Olson, J. S. (2003). Human-computer interaction: psychological aspects of the human use of computing. Annual Reviews: Psychology, 54, 491-516.

Organização Internacional do Trabalho - OIT (2013). Doenças profissionais são as principais causas de mortes no trabalho. http://www.oitbrasil.org.br/content/doencasprofissionais-sao-principais-causas-de-mortes-no-trabalho. Acesso em 09/06/2016.

Ouriveis, M. (2013). Acumulação flexível, tecnologia e mudanças no mundo do trabalho: da reestruturação produtiva aos home offices. Estudos do Trabalho: 12, 1-23.

Paschoal, T., Torres, C. V.; Porto, J. B. (2010). Felicidade no trabalho: relações com suporte organizacional e suporte social. Revista de Administração Contemporânea (RAC), 14 (6), 1054-1072.

Paschoal, T.; Tamayo, A. (2008). Construção e validação da escala de bem-estar no trabalho. Avaliação Psicológica, 7 (1), 11-22.

Pedroso, B.; Pilatti, L. A. (2010). Revisão literária dos modelos clássicos de avaliação da qualidade de vida no trabalho: um debate necessário. Qualidade de vida: evolução, conceitos e práticas no século XXI, 197-206.

Pedroso, B.; Pillati, L. A.; Santos, C. B.; Santos Júnior, G. (2010). Potencial motivador do trabalho: tradução e adaptação cultural do instrumento de Hackman e Oldham. Revista Produção Online, 10 (3), 670-697.

Périco, W.; Justo, J.S. (2011). 0 mal estar no trabalho: a culpa como mal estar e a culpa do mal estar. Revista Mal-Estar e Subjetividade, 11 (1), 135-169.

Pinto, C.L.L.; Goes, R.I.G; Katrein, B.H.; Barreiro, C.B. (2013). Entre o bem e o mal-estar: a intensificação do trabalho docente no âmbito dos Institutos Federais de Educação, Ciência e Tecnologia. Revista Educação por Escrito, 4(1), 44-58.

Pizzio, A.; Klein, K. (2015). Qualidade de vida no trabalho e adoecimento no cotidiano de docentes do ensino superior. Educação e Sociedade, 36 (131), 493-513).
Ranieri, J. (2001). A câmara escura: Alienação e estranhamento em Marx. São Paulo, SP: Boitempo.

Rauber, A.M.T.R; Rebolo, F. (2011). Trabalho docente: o malestar e os desafios da profissão na conquista do prazer, do bem-estar e da felicidade. Anais do IV Seminário Povos Indígenas: saberes tradicionais e formação acadêmica, 1, 1 $-12$

Rebecchi, E. (1990). O sujeito frente à inovação tecnológica. Petrópolis: Vozes.

Reinert, M. (1990). Alceste: une methologie d'analyse dês donnees textualles et une application. Em A G. Neval. Bulletin de Méthodologie Sociologique, 28, 24-54.

Reis, B. M. (2013). Trabalho docente e qualidade de vida. Revista Encontro de Pesquisa em Educação, 1(1), 37-48.

Ribeiro, C. V. S. (2009). A saúde do servidor público em tempos de gerencialismo. Encontro Nacional da Associação Brasileira de Psicologia Social, 15, Maceió. Maceió: UFAL, 2009.

Robbins, S. P. (2010). Comportamento Organizacional. São Paulo: Pearson Prentice Hall.

Rodrigues, M. V. C. (2011). Qualidade de Vida no Trabalho: evolução e análise no nível gerencial. $13^{\mathrm{a}}$ ed. São Paulo: Ed. Vozes.

Ryan, R.M.; Deci, E.L. (2001). On happiness and human potentials: a review of research on eudaimonic well-being. Annual Review of Psychology, 52, 141-166.

Sampaio, J. R. (2012). Qualidade de vida no trabalho: perspectivas e desafios atuais. Revista Psicologia Organizacional e Trabalho, 12 (1), 121-136.

Santos, G.B.; Ceballos, A.G.C. (2013). Bem-estar no trabalho: estudo de revisão. Psicologia em Estudo, 18(2), 247-255.

Santos, L.A. (2014). "Quando chega domingo, fico triste de ter que trabalhar na segunda": a qualidade de vida no trabalho em questão no serviço público federal. Tese de doutorado, Programa de Pós-Graduação em Psicologia Social, do Trabalho e das Organizações (PSTO), Universidade de Brasília, Brasília, DF, Brasil.

Santos, M.S. (2008). Ergonomia de concepção na prevenção de inadequações no ambiente de trabalho construído. Ação Ergonômica, 3(2), 16-24.

Schulte, P; Vainio, H. (2010). Well-being at work - overview and perspective. Scandinavian Journal of Work, Environment \& Health, 36(5), 422-429).

Sennet, R. (1999). A corrosão do caráter: conseqüências pessoais do trabalho no novo capitalismo. Rio de Janeiro, RJ: Record. 


\section{REFERÊNCIAS GERAIS}

Silva, N. (2005). O mal-estar da professora alfabetizadora: contribuições de D. Winnicot. Revista Mal-Estar e Subjetividade, 5(1), 11-44.

Silva, R.R. (2009). Home officer: um surgimento bem-sucedido da profissão pós-fordista, uma alternativa positiva para os centros urbanos. Revista Brasileira de Gestão Urbana, 1(1), 85-94.

Siqueira, M.M.M.; Padovam, V.A.R. (2008). Bases teóricas de bem-estar subjetivo, bem-estar psicológico e bem-estar no trabalho. Psicologia: Teoria e Pesquisa, 24(2), 201-209.

Sirgy, M. J.; Efraty, D.; Siegel, P.; Lee, D. (2001). A New Measure of Quality of Work Life (QWL) Based on Need Satisfaction and Spillover Theories. Social Indicators Research, 55 (3), 241-302.

Timm, E.Z.; Mosquera, J.J.M.; Stobäus, C.D. (2010). 0 mal-estar na docência em tempos líquidos de modernidade. Revista Mal-Estar e Subjetividade, 10(3), 865-885.

Todeschini, R.; Ferreira, M. C. (2013). Olhar de dirigentes sindicais sobre Qualidade de Vida no Trabalho e mal-estar no trabalho. Estudos de Psicologia, 18 (2), 241-247.

Tolfo, S. R.; Silva, N.; Luna, I. N. (2009). Cultura organizacional identidade e qualidade de vida no trabalho: articulações e sugestões de pesquisas em organizações. Pesquisas e práticas psicossociais, 4 (1), 6-16.

Van de Ven, A. H. (1986). Central problems in the management of innovation. Management Science, 32 (5), 590-607.
Vasconcelos, A. F. (2001). Qualidade de vida no trabalho: origem, evolução e perspectivas. Caderno de Pesquisas em Administração, 8 (1).

Viegas, W. (1999). Fundamentos de metodologia científica. Brasília: Paralelo 15, Editora Universidade de Brasília.

Walton, R. E. (1973). Quality of working life: what is it? Slow Management Review: 15 (1), 11-2.

Werther, B. W; Davis, K. (1983). Administração de pessoal e recursos humanos: a qualidade de vida no trabalho. São Paulo: Mcgraw-Hill do Brasil.

Westley, .W. A. (1979). Problems and Solutions in the Quality of Working Life. Human Relations, 2 (32), 113-23.

Wisner, A. (2004). Questões epistemológicas em ergonomia e em análise do trabalho. Em F. Daniellou (Org.), $A$ Ergonomia em busca de seus princípios: Debates epistemológicos (pp. 29-56). São Paulo: Edgard Blücher.

Wisner, A. (1992). A antropotecnologia. Estudos Avançados: 6 (16), 29-34.

Yin, R.K. (2005). Estudo de caso: planejamento e métodos. 3 ed. Porto Alegre: Bookman.

Zhao, X. W.; Sun, T.; Cao, Q.; Li, C.; Duan, X.; Fan, L.; Liu, Y.; (2012). The impact of quality of work life on job embeddedness and affective commitment and their coeffect on turnover intention of nurses. Journal of Clinical Nursing, 22, 780-788. 


\section{APÊNDICE}

\section{EXEMPLOS DE MÍDIAS DE SENSIBILIZAÇÃO - MACRODIAGNÓSTICO}

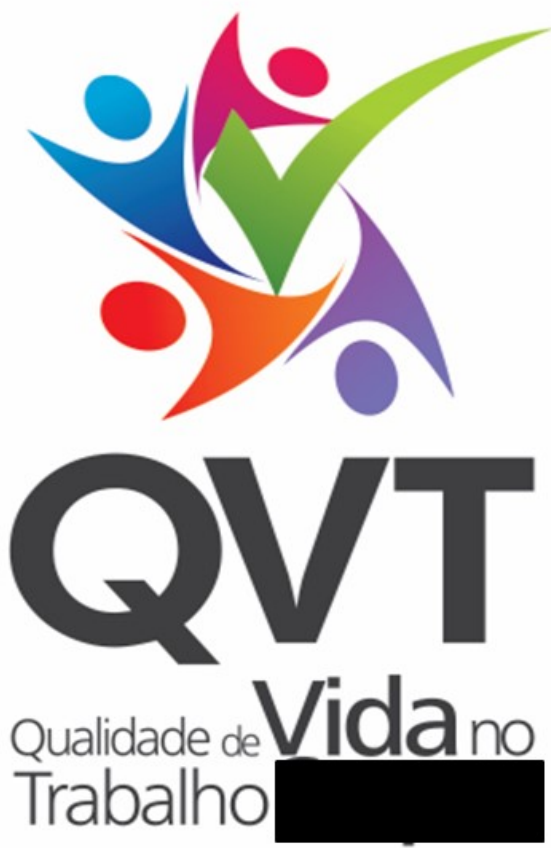

Logo da pesquisa
Qual a sua opinião sobre a Qualidade de Vida no Trabalho (QVT) no

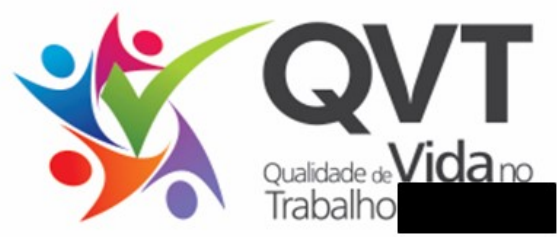

Em breve você receberá uma senha aleatória e confidencial que lhe dará acesso anônimo a um questionário eletrônico sobre a QVT no

A pesquisa se estende a todos os empregados, terceirizados, estagiários e jovens aprendizes.

O questionário estará disponível de 2 a 13 de setembro, no endereço

www.ergopublic.com.br

\section{Participe!}

Os resultados da pesquisa serviróo de base para pautar as próximas açóes de QVT no Serpro. A sua colaboraçáo será novamente solicitad
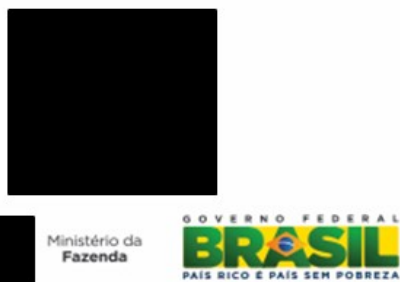
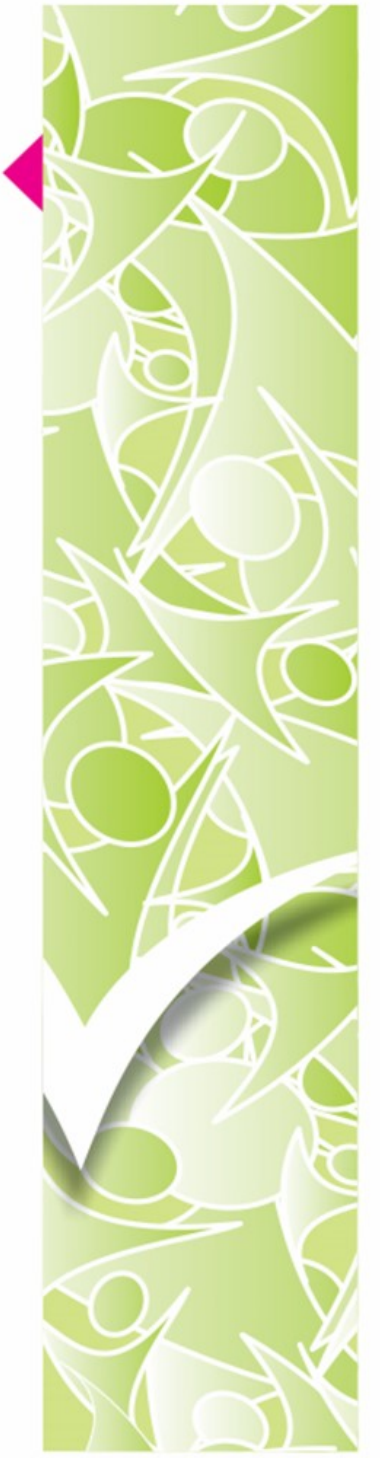


\section{MODELOS E ROTEIROS DOS INSTRUMENTOS DE COLETA DE DADOS - MICRODIAGNÓSTICO}
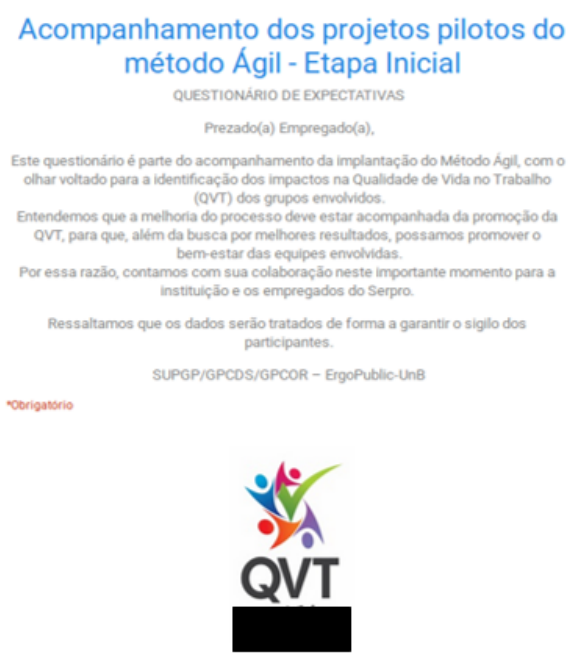

1. Considerando globalmente o processo de implantação do Método Ágil para Entrega de Soluçōes no a nota que atribuo à minha expectativa é... *

$\begin{array}{lllllllllll}0 & 1 & 2 & 3 & 4 & 5 & 6 & 7 & 8 & 9 & 10\end{array}$

Muito negativa 00000000000 Muito positiva

2. Complementando minha visão, minhas principais expectativas são: *

A) Expectativas positivas

B) Expectativas negativas
Fatores de Qualidade de Vida no Trabalho

3. Considerando globalmente cada um dos fatores abaixo, os quais estão detalhados por meio de alguns dos seus principais elementos constituintes, atribua uma nota entre 0 e 10 que corresponda às suas expectativas em relação ao processo de implantação do Método Ágil:

\subsection{Organizaçāo do Trabalho *}

Caracteristicas principais, entre outras: trabalho prescrito (planejamento, tarefas, regras formais e Caracteristicas principais, entre outras: trabalho prescrito (planejamento, tarefas, regras formais e
informais, prazos), tempo de trabalho (jornada, duraçăo, turnos, pausas, férias, flexibilidade), processo de trabalho (ciclos, etapas, ritmo previsto, tipos de pressão).

$$
\begin{array}{lllllllllll}
0 & 1 & 2 & 3 & 4 & 5 & 6 & 7 & 8 & 9 & 10
\end{array}
$$

Muito negativa 00000000 Muito positiva

\subsection{Condicōes de Trabalho*}

Caracteristicas principais, entre outras: ambiente fisico (espaços de trabalho, iluminaçăo, temperatura, acústica) instrumental (máquinas, ferramentas, documentaçăo), suporte organizacional (informaçōes,

$$
\begin{array}{lllllllllll}
0 & 1 & 2 & 3 & 4 & 5 & 6 & 7 & 8 & 9 & 10
\end{array}
$$

Muito negativa $\bigcirc \bigcirc \bigcirc \bigcirc \bigcirc \bigcirc \bigcirc \bigcirc \bigcirc \bigcirc$ Muito positiva

3.3 Relaçōes Socioprofissionais *

Caracteristicas principais, entre outras: interaçāo hierárquica (relação com chefias imediatas superiores), interaçāo com pares (colegas da mesma equipe e dentro da unidade organizacional),

$$
\begin{array}{llllllllllll}
0 & 1 & 2 & 3 & 4 & 5 & 6 & 7 & 8 & 9 & 10
\end{array}
$$

Muito negativa 00000000000 Muito positiva

3.4 Práticas de Gestảo *

Caracteristicas principais, entre outras: participação (envolvimento nas decisōes sobre organizaçāo das tarefas), hierarquia (distribuiçăo das tarefas na equipe), liberdade (execução de tarefas).

$\begin{array}{llllllllllll}0 & 1 & 2 & 3 & 4 & 5 & 6 & 7 & 8 & 9 & 10 \\ \text { Muito negativa } \bigcirc & \bigcirc & \bigcirc & \bigcirc & \bigcirc & \bigcirc & \bigcirc & \bigcirc & \bigcirc & \bigcirc & \bigcirc & \text { Muito positiva }\end{array}$

4. Caso queira complementar as informaçōes acima, utilize o campo abaixo para incluir comentários a respeito dos fatores abordados.

\section{Questionário de expectativas}

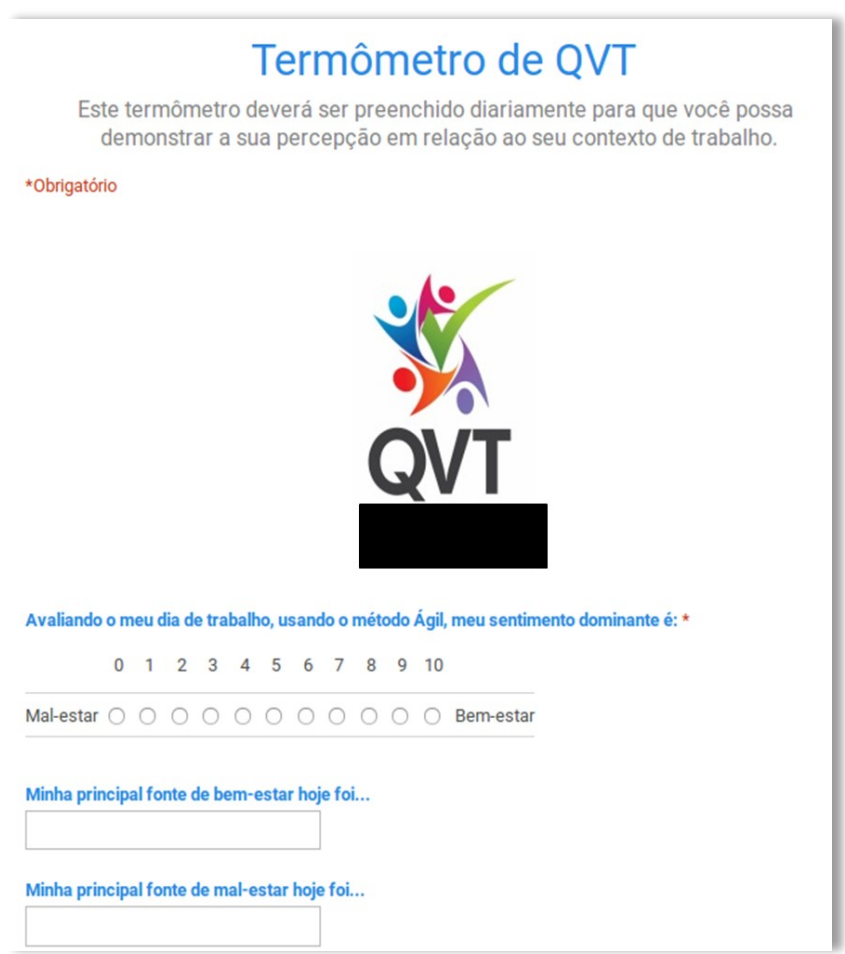

Termômetro de QVT 


\section{Roteiro - Grupo Focal 1}

\section{Questões abordadas:}

1. Quando penso no meu trabalho no método Ágil, o principal problema existente é...

2. Esse problema provoca como consequência principal...

3. Para enfrentar tais consequências (evitar, prevenir, atenuar), eu faço...

4. Para resolver tal problema, julgo importante realizar...

\section{Roteiro - Grupo Focal 2}

\section{Questões abordadas:}

1. Minha nota global para a implantação do método Ágil no XXXX é... (0 - 10). Justifique.

2. Minha nota global para a Organização do Trabalho é... (0 - 10). Justifique.

3. Minha nota global para as Condições do Trabalho é... (0 - 10). Justifique.

4. Minha nota global para as Relações Socioprofissionais é... (0 - 10). Justifique.

5. Minha nota global para as Práticas de Gestão é... (0 - 10). Justifique. 